WSRC-RP-93-0878,-Rev. 1,- Vol.l

\title{
Economic Evaluation of Closure CAP Barrier Materials Volume I and Volume II (U)
}

by

M. G. Serrato

Westinghouse Savannah River Company

Savannah River Site

Aiken, South Carolina 29808

J. S. Bhutani

S. M. Moad

DOE Contract No. DE-AC09-89SR18035

This paper was prepared in connection with work done under the above contract number with the U.S.

Department of Energy. By acceptance of this paper, the publisher and/or recipient acknowledges the U.S.

Government's right to retain a nonexclusive, royalty-free license in and to any copyright covering this paper, along with the right to reproduce and to authorize others to reproduce all or part of the copyrighted paper. 


\section{DISCLAIMER}

Portions of this document may be illegible in electronic image products. Images are produced from the best available original document. 


\section{Table of Contents}

\section{Volume I}

Acknowledgments

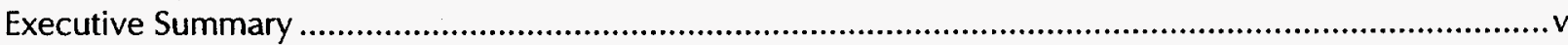

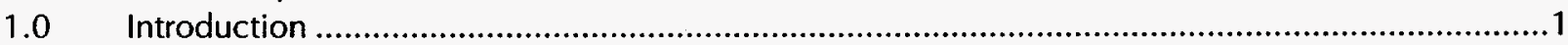

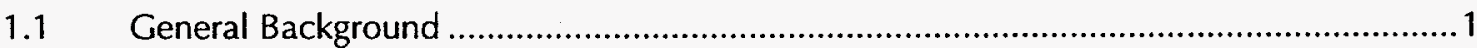

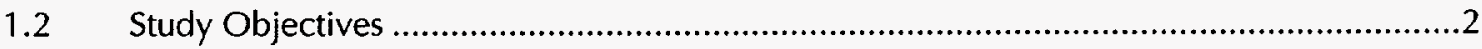

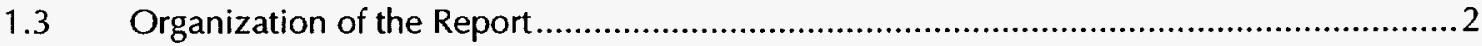

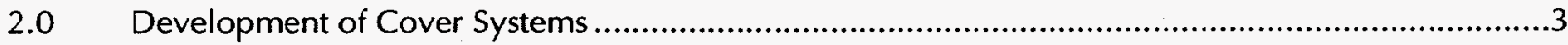

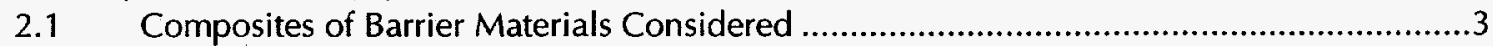

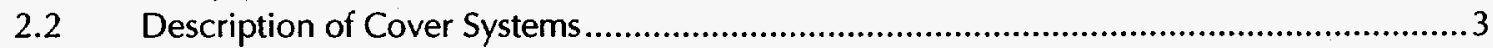

2.2.1 Cover System 1 - Cover System Utilizing Claymax® and a 30-mil FML ............... 3

2.2.2 Cover System 2 - Cover System Utilizing Bentomat $\circledast$ and a 30-mil FML ..............5

2.2.3 Cover System 3 - Cover System Utilizing Gundseal $($........................................5

2.2.4 Cover System 4 - Cover System Utilizing 120-mil High Density Polyethylene (HDPE)

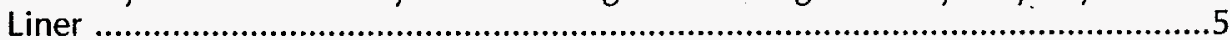

2.2.5 Cover System 5 - Cover System Utilizing 1/4-inch Thick Hot Sprayed or Emulsified Asphalt...............................................................................................5

2.2.6 Cover System 6 - Cover System Utilizing Reinforced Sprayed Asphalt ................5

2.2.7 Cover System 7 - Cover System Utilizing Compacted Kaolin (Offsite) Clay and 30-mil FML..............................................................................................5

2.2.8 Cover System 8 - Cover System Utilizing Compacted Onsite Sandy Clay and 30-mil FML

2.2.9 Cover System 9 - Cover System Utilizing Soil Cement and 30-mil FML..............12

2.2.10 Cover System 10 - Cover System Utilizing Bentonite Soil Additive and 30-mil FML

2.2.11 Cover System 11 - Cover System Utilizing Asphalt Concrete Hydraulic Barrier and 30-mil FML.

2.2.12 Cover System 12 - Cover System Utilizing Poured-in-Place Concrete Slab and 30-mil FML

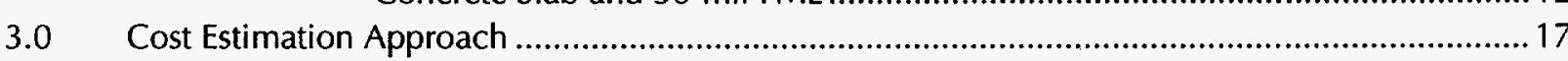

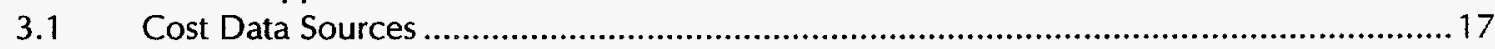

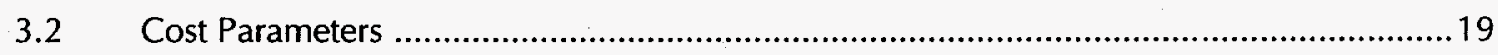

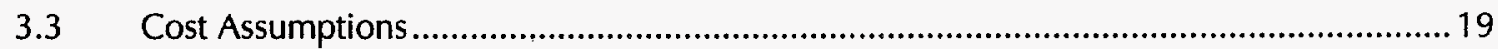

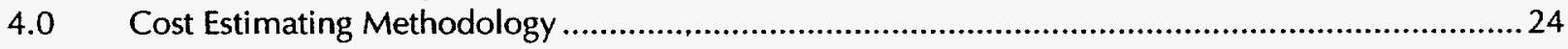

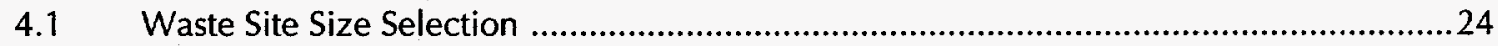

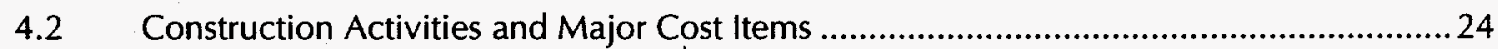

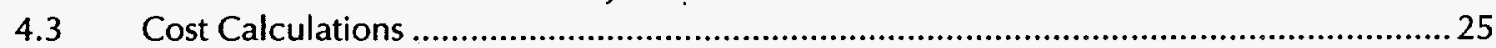

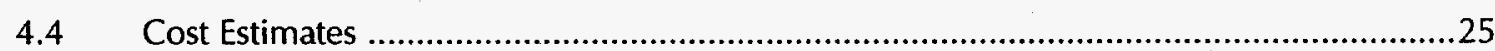

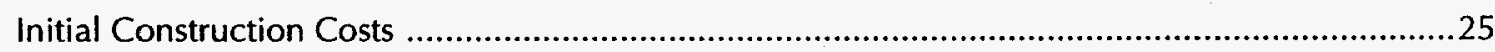

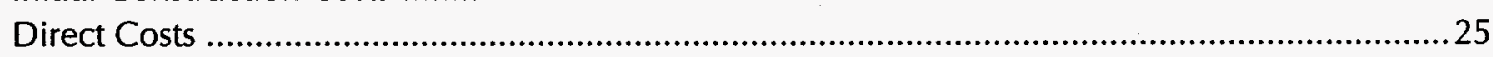

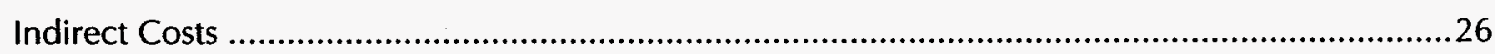

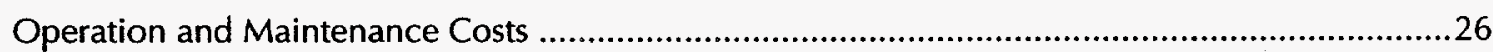

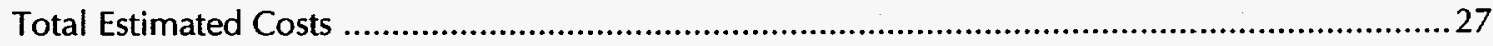




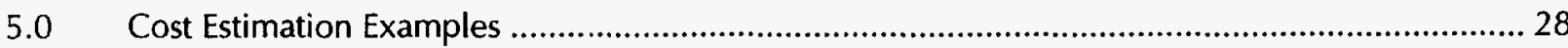

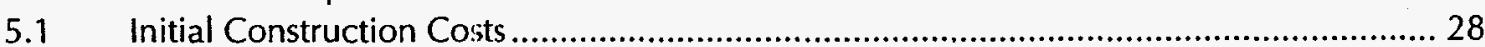

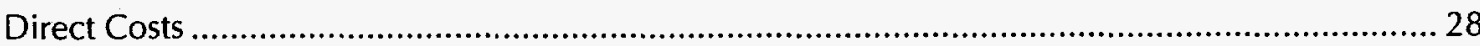

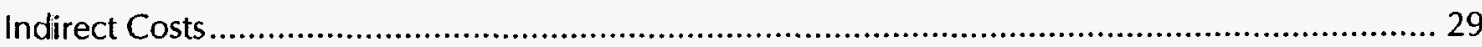

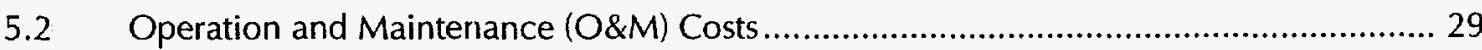

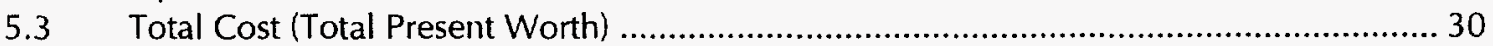

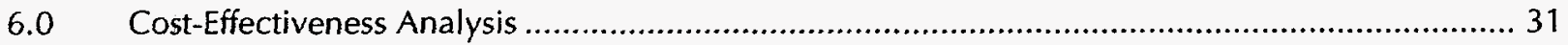

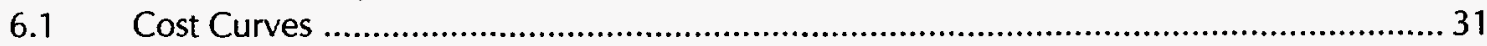

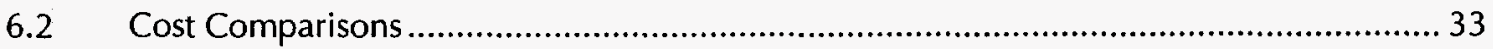

6.2.1 Site Size 0.1 Acre to 10 Acres ......................................................................... 33

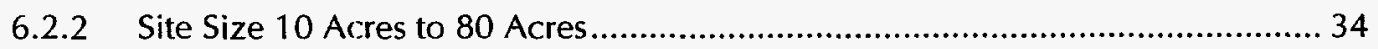

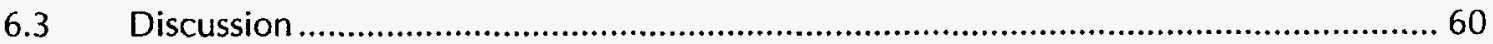

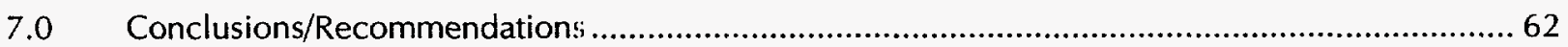

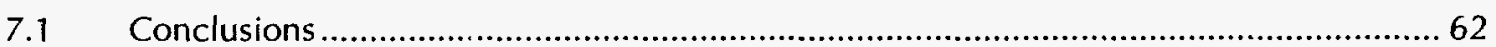

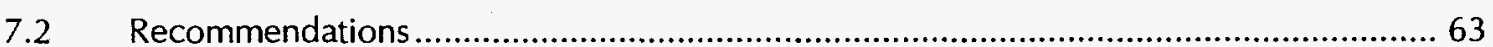

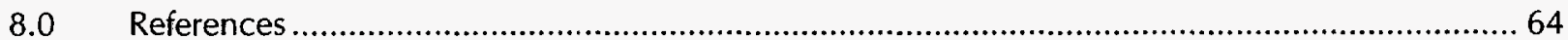

\section{Figures}

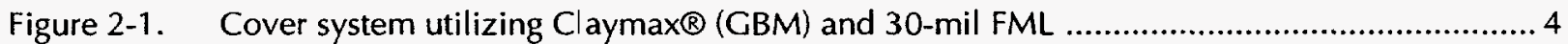

Figure 2-2. Cover system utilizing Bentomat $($ (GBM) and 30-mil FML ......................................... 6

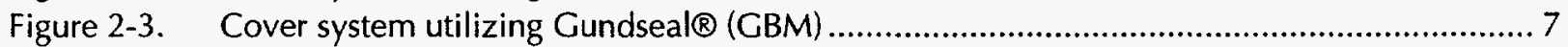

Figure 2-4. Cover system utilizing 120-mil flexible membrane liner (FML) ..................................... 8

Figure 2-5. Cover system utilizing hot-sprayed or emulsified asphalt ............................................ 9

Figure 2-6. Cover system utilizing reinforced sprayed asphalt ........................................................ 10

Figure 2-7. Cover system utilizing offsite/onsite compacted clay and 30-mil FML ............................ 11

Figure 2-8. Cover system utilizing soil cement and 30-mil FML ............................................... 13

Figure 2-9. Cover system utilizing bentonite soil additive and 30-mil FML.................................... 14

Figure 2-10. Cover system utilizing hydraulic asphalt concrete and 30-mil FML .............................. 15

Figure 2-11. Cover system utilizing poured-in-place ................................................................. 16

Figure 3-1. Plan for a typical one-acre waste site cover system ....................................................... 22

Figure 3-2. Section through a typical one-acre size landfill cover ................................................. 23

Figure 6-1. Column charts showing barrier material costs for 0.1 acre site ........................................ 35

Figure 6-2. Column charts showing barrier material costs for 0.2 acre site ................................... 36

Figure 6-3. Column charts showing barrier material costs for 0.5 acre site ....................................... 37

Figure 6-4. Column charts showing barrier material costs for 1 -acre site ...................................... 38

Figure 6-5. Column charts showing barrier material costs for 2 -acre site........................................ 39

Figure 6-6. Column charts showing barrier material costs for 5 -acre site ..................................... 40

Figure 6-7. Column charts showing barrier material costs for 10 -acre site ....................................... 41

Figure 6-8. Column charts showing barrier material costs for 20 -acre site ...................................... 42

Figure 6-9. Column charts showing barrier material costs for 40 -acre site ..................................... 43

Figure 6-10. Column charts showing barrier material costs for 80 -acre site ...................................... 44

Figure 6-11. Composite relative man -hour requirements for each barrier materials and

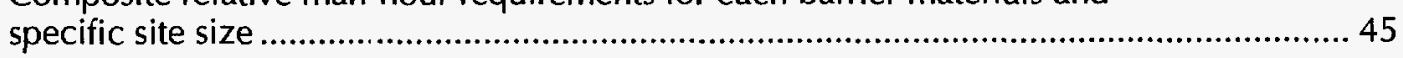

Figure 6-12. Composite cost curves showing life cycle cost per square foot..................................... 56

Figure 6-13. Composite cost curves showing life cycle cost per square foot..................................... 57

Figure 6-14. Composite cost curves showing life cycle cost per square foot................................... 58

Figure 6-15. Composite cost curves showing life cycle cost per square foot..................................... 59 


\section{Tables}

Table 3-1. Barnwell County Low-Level Radioactive Waste Disposal Facility, ...................................18

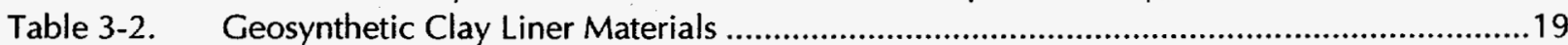

Table 6-1. Cover System Estimates Costs Summary....................................................................35

Table 6-2. Estimated Costs(1) For 0.1 Acre Site ..................................................................46

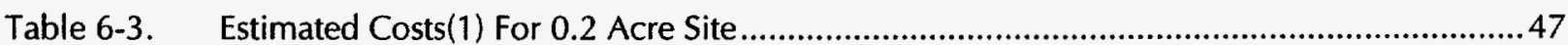

Table 6-4. Estimated Costs(1) For 0.5 Acre Site.....................................................................48

Table 6-5. Estimated Costs(1) For 1.0 Acre Site $\quad$......................................................................49

Table 6-6. Estimated Costs(1) For 2.0 Acre Site $\quad$..................................................................50

Table 6-7. Estimated Costs(1) For 5.0 Acre Site................................................................... 51

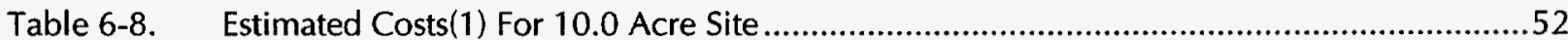

Table 6-9. Estimated Costs(1) For 20.0 Acre Site .................................................................53

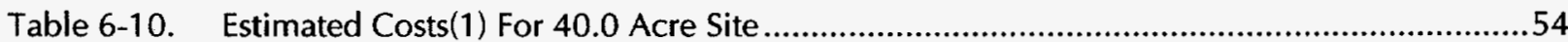

Table 6-11. Estimated Costs(1) For 80.0 Acre Site ................................................................55

\section{Appendices}

Appendix A Configuration of the Cover Systems and Major Construction Activities Involved for Their Individual Construction

Appendix B Cost Estimate for a Typical 1-Acre Site

Appendix C Data for Calculating Subsidence Failures Repair Costs

\section{VOLUME II (Bound Separately)}

Cost Estimates for 0.1 Acre Site Through 80 Acres Site 


\section{Acknowledgments}

This study was prepared as a part of the ongoing efforts by the Site Geotechnical Services (SGS) and Environmental Restoration (ER) departments of the Westinghouse Savannah River Company (WSRC) to select the most cost-effective and reliable barrier material for a given Savannah River Site (SRS) hazardous waste site. The study involved a major effort by the Cost Estimating, Procurement and Materials Management departments of the WSRC Engineering and Projects Division in developing unit prices and preparing cost estimates. The number of personnel who cooperated in this endeavor is too large to list here, but we have attempted to identify those individuals whose contributions were of great value.

We wish to express our thanks to the following: James W. Iwert, manager Project Control and Cost Estimating, for his timely help and cooperation throughout the project; M. Shakoor and William Kulp for developing unit prices and for their keen interest in checking the cost estimates to make sure the estimates reflect the most possible cost of covering a given SRS site; and Pravina Ghelani for her most valuable help in preparing and typing the cost estimates. 
Economic Evaluation of Closure Cap Barrier Materials (U)
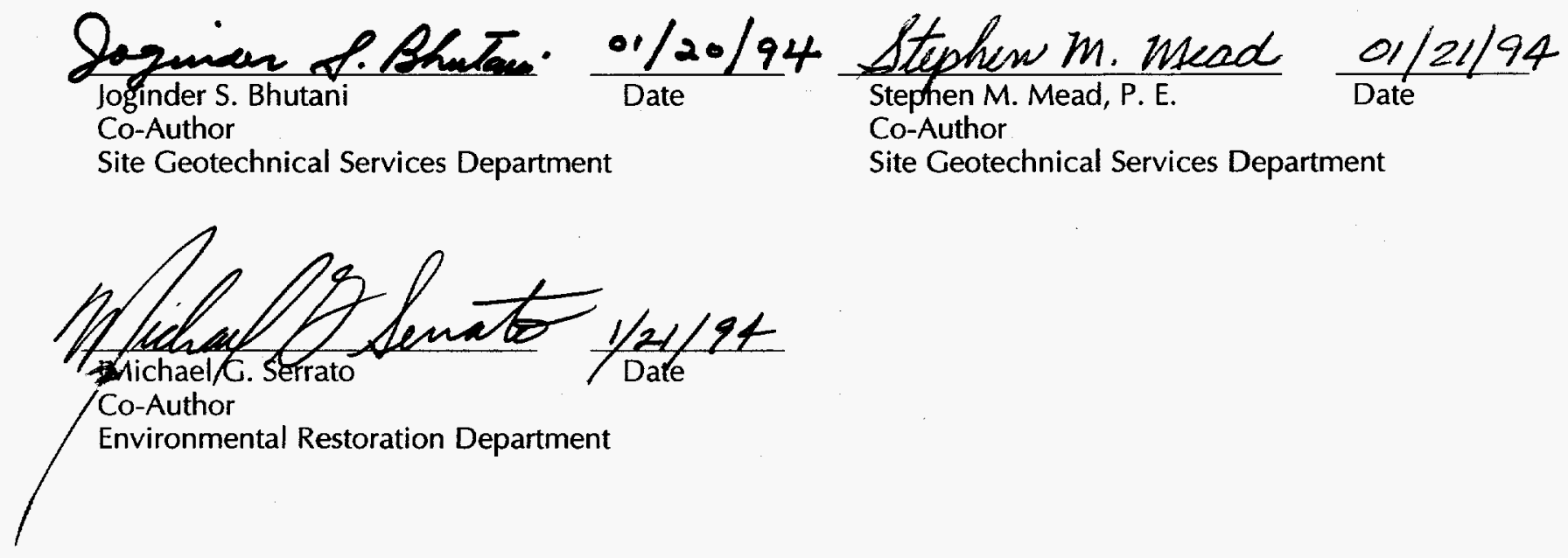

Westinghouse Savannah River Company Savannah River Site

Aiken, SC 29808

Approved by:
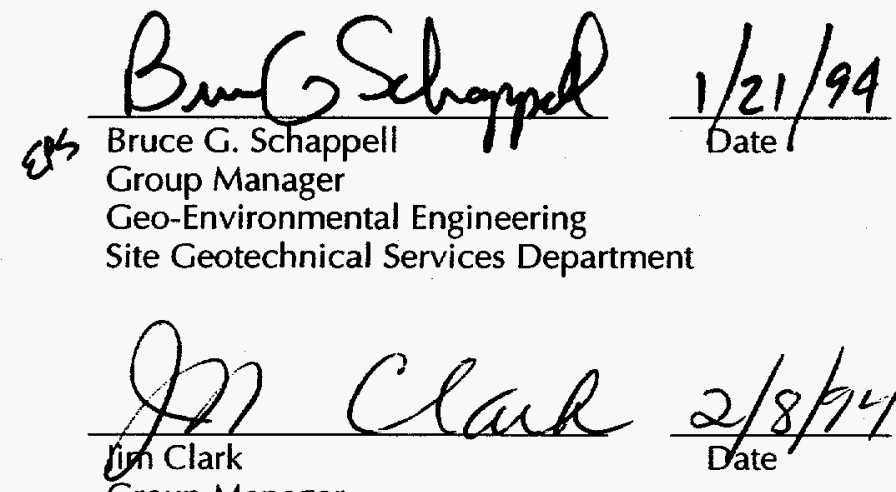

Group Manager

Engineering Support

Environmental Restoration Department

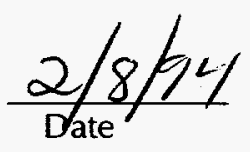

Group Manager

Remedial Assessments

Environmental Restoration Department

Approved by:

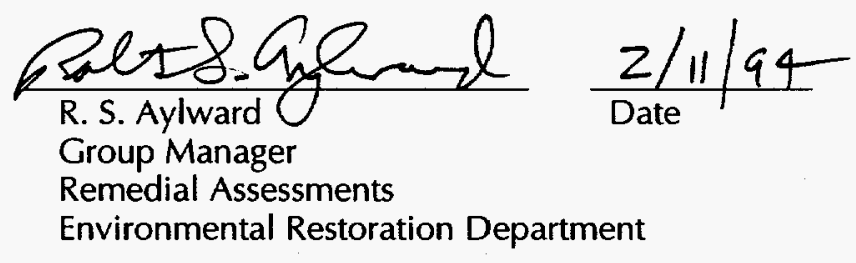




\section{Disclaimer}

This report was prepared as an account of work sponsored by an agency of the United States Government. Neither the United States Government nor any agency thereof, nor any of their employees, makes any warranty, express or implied, or assumes any legal liability or responsibility for the accuracy, completeness, or usefulness of any information, apparatus, product, or process disclosed, or represents that its use would not infringe privately owned rights. Reference herein to any specific commercial product, process, or service by the trade name, trademark, manufacturer, or otherwise, does not necessarily constitute or. imply its endorsement, recommendation, or favoring by the United States Government or any agency thereof. The views and opinions of authors expressed herein do not necessarily state or reflect those of the United States Government or any agency thereof. 


\section{Executive Summary}

This study prepared by the SGS and ER departments of the WSRC evaluates a generic closure cover system for a surface impoundment, using 10 different surface areas, ranging from 0.1 acre to 80 acres, and 12 barrier materials. This study presents a revision to the previous study (Rev. 0) published in June 1993, under the same title. The objective of this study was to revise the previous study by incorporating four additional site sizes into the evaluation process and identifying the most cost-effective barrier material for a given closure cover system at the SRS.

This report is not intended to be used as a cost estimating manual. The information contained in this report provides decision makers with the ability to screen barrier materials and to identify cost-effective materials for further consideration.

\section{Cost Estimation Approach}

The cost-estimation approach for hazardous waste sites is unique in its characteristics that preclude using standard engineering, cost-estimating methodologies. A bottom line project is presented in this report based on actual life-cycle project expenses and estimates. Cost data were compiled from various sources ranging from published literature and industry cost indexes to actual project costs for previous closure projects at SRS and the commercial industry. Based on this information, cost parameters and assumptions were developed for cost estimating.

\section{Cost Estimating Methodology}

The cost-estimating methodology developed for this evaluation incorporated the following parameters:

- waste site size

- direct construction costs specific to individual barrier material and/or cover system configuration

- indirect costs associated with installing the barrier material and/or cover system configuration

- post monitoring and maintenance costs.

Based on these parameters, a series of cost estimates were developed for each barrier material. Thirty-year life-cycle costs operations and maintenance (O\&M) were projected, brought back to present worth costs, and incorporated into the evaluation process. Several graphs, depicting barrier materials versus surface areas, were developed to identify the most cost-effective barrier material for a given surface area.

\section{Conclusions and Recommendations}

The most cost-effective barrier material configuration for a closure cover system for SRS waste sites is a composite geosynthetic clay liner. This configuration provides a redundant hydraulic barrier and a compacted sandy clay soil for structural strength at a low material cost. The composite geosynthetic clay liner cover system meets and exceeds the Resource Conservation and Recovery Act/Comprehensive Environmental Response, Compensation, and Liability Act (RCRA/CERCLA) requirements.

Barrier material cost-effectiveness and project duration are impacted by whether the barrier material is manufactured or constructed in place. A breakpoint among the project sizes 
evaluated was 10 acres. For 10-acre sites, only material cost is significant. For sites larger than 10 acres, the material cost and the project duration are the most significant considerations based upon the influence of the economy-of-scale for the larger project sites.

It is recommended that a composite cover system configuration be the primary configuration of consideration for a cover system at SRS. The composite geosynthetic clay liner configurations are recommended.

It is further recommended that test-pad field investigations be conducted to verify the performance characteristics of the recommended configurations under actual field conditions. Regulatory consultation, such as South Carolina Department of Health and Environmental Control (SCDHEC), will be sought during the screening of alternative configurations.

For smaller waste sites with little potential for subsidence, configuration composed of compacted onsite sandy clay soil and a 30 -mil flexible membrane liners (FML) is recommended.

Several waste site closure projects are either ongoing or are scheduled to be completed in upcoming years. The cost data generated from these future projects should be tracked and entered into a cost-estimating database. It is recommended that at some future date, this study be revised to reflect the actual costs encountered for constructing various closure projects at SRS. 


\subsection{Introduction}

\subsection{General Background}

This study, which presents a revision to the previous study (Rev. 0) ${ }^{1}$ published in June 1993, under the same title, has been prepared in two volumes. Volume I contains the text of the report and information and data used to develop the cost estimates. Volume II contains detailed cost estimates.

Both studies (Rev. 0 and Rev. 1) present an economic analysis of the selected cap barrier materials for SRS closure sites. Details of these barrier materials have been discussed in a separate study, Closure Cap Barrier Materials Evaluation Study - Phase I. ${ }^{2}$ In the previous study (Rev. 0), cost estimates of six different sizes of waste sites ( 0.1 acre, 0.2 acre, 0.5 acre, 1 acre, 2 acres, and 5 acres) were developed. In this study, cost estimates for four additional site sizes ( 10 acres, 20 acres, 40 acres, and 80 acres) have been developed. The economic analysis presented in this report provides a greater range in selecting the most cost-effective barrier material for a given SRS site from the candidate materials for closure under RCRA/CERCLA guidelines.

The closure cap barrier material evaluation study assessed the compatibility of the commercially available barrier materials to SRS waste sites. In that study, a number of parameters representing SRS waste sites were discussed. Based on these parameters, the study was concerned with the following:

- characterization of SRS hazardous waste sites and grouping the waste sites into eight categories

- evaluation of commercially available geosynthetic barrier materials for their application to SRS sites

- selection of the most appropriate barrier material(s) for each waste site.

The report identified six categories of barrier materials as appropriate for developing closure cap system designs for SRS sites.

The selection of barrier materials was based upon a review of literature and compatibility of barrier materials with SRS characteristics. The following six categories of barrier materials were selected for evaluation:

- geosynthetic clay liners (geotextile bentonite mats)

- flexible membrane liners

- asphalt barriers

- clays

- soil additive materials (soil-cement and bentonite)

- other nonsoil materials (concrete)

This report evaluates 12 barrier materials belonging to these categories and their costeffectiveness. A total of 120 cost estimates have been developed using 10 different sizes of waste sites for each barrier material. Each cost estimate consists of three major cost parameters

- initial construction costs

- O\&M costs

- total present worth (1994 costs) amortized over the 30-year life cycle 
Based on these cost estimates, tables were prepared summarizing the associated costs for each barrier material per site size. These tables also rank the material from least to most expensive in terms of costs per square foot.

This report is intended to provide guidance to environmental restoration project team members, planners, and decision makers in selecting the most cost-effective barrier materials for covering potential SRS hazardous waste sites. However, this report is not intended as a design or a cost estimating manual. The primary objectives of this report are to develop a preliminary baseline for construction cost data and compare various barrier systems for their cost-effectiveness. The information contained in this report provides decision makers with the ability to screen barrier materials and identify cost-effective materials for further consideration. It is expected that the cost information provided in this report will be valuable during all phases of a given closure project, including the initial planning, project formulation, and preliminary engineering report.

\subsection{Study Objectives}

The primary objectives for revising this report were to develop a construction cost database for four additional waste site sizes; revise cost estimates for six waste site sizes considered in Rev. 0 to reflect: 1994 costs; and provide a larger resource database for selecting the most cost-effective barrier material for a SRS waste site in relation to the site's characteristics and size. To accomplish these objectives, the following four major tasks were involved:

- collecting current cost data pertaining to procurement, installation, maintenance, and other related costs, [i.e., quality assurance/quality control (QAQC) cost, health protection cost, etc.] for each of 12 barrier materials considered for economic analysis

- developing cost estimates (initial construction cost, O\&M cost, and total present worth) for each of the 12 barrier materials, estimates for four additional sizes of waste sites (10 acres, 20 acres, 40 acres, and 80 acres) were completed

- revising cost estimates for the six previously considered waste site sizes ( 0.1 acre, 0.2 acre, 0.5 acre, 1 acre, 2 acres, and 5 acres) to reflect 1994 costs

- developing new cost curves relating the waste site size (extended to 80 acres) with the estimated total cost per square foot of covering the site with a specific barrier material

- revising comparative cost analyses to include additional sizes of waste sites and to determine the most cost-effective waste site size for each barrier material

\subsection{Organization of the Report}

This report has been divided into two volumes. Volume I of this report is divided into eight sections and three appendices. Section 1.0 provides a general background and identifies the major objectives of the study. Section 2.0 describes the cover system configurations developed for the economic analyses. Section 3.0 describes the cost-estimating approach, identifies the cost data sources, and provides information on cost parameters and cost assumptions used for cost estimating. Section 4.0 presents the methodology for cost estimating and the basis used for developing cost estimates. For illustrative purposes, an example of computing the costs of various construction activities and preparing the cost estimate is provided in Section 5.0. Section 6.0 provides revised cost comparisons and specifies the most cost-effective waste site size for each barrier material. Section 7.0 discusses the findings of this study along with recommendations for future work. Section 8.0 provides the list of references used in developing this report. Appendices include pertinent information used to develop detailed cost estimates. Volume II of this report contains cost estimates. 


\subsection{Development of Cover Systems}

\subsection{Composites of Barrier Materials Considered}

The following 12 composite cover systems were developed for economic evaluations:

\section{Barrier Material Category}

- Geosynthetic clay liners

- Flexible membrane liner

- Asphalt barriers

- Clays

- Soil additives

- Nonsoil materials

\section{Composite Cover System}

- Claymax ${ }^{\circledR}$ and 30-mil FML

- Bentomat ${ }^{\circledR}$ and 30-mil FML

- Gundseal ${ }^{\circledR}$

- 120-mil high-density polyethylene (HDPE) liner

- 1/4-inch-thick hot sprayed or emulsified asphalt and 30-mil FML

- 1/4-inch-thick reinforced sprayed asphalt with geotextile fabric and 30-mil FML

- Kaolin clay (offsite) and 30-mil FML

- Onsite clay and 30-mil FML

- Soil cement and 30-mil FML

- Bentonite soil and 30-mil FML

- 4-inch-thick asphalt concrete slab and 30-mil FML

- 4-inch-thick poured-in-place concrete slab and 30-mil FML

\subsection{Description of Cover Systems}

The 12 cover system configurations developed for these economic evaluations are described in this section. Each configuration complies with the guidance for hazardous waste closure cover system performance characteristics as outlined by the U. S. Environmental Protection Agency (EPA). The detailed design specifications and major construction activities, along with the postclosure monitoring and maintenance activities associated with each cover system configuration are contained in Appendix A.

\subsubsection{Cover System 1 - Cover System Utilizing Claymax ${ }^{\circledR}$ and a 30- mil FML}

The cover system consists of a 2-foot-thick, low-permeability layer (compacted soil foundation layer) covered by a 1/4-inch-thick Claymax ${ }^{\circledR}$ sheet and 30-mil FML (Figure 2-1). The cover system's additional layers are a 1-foot-thick drainage layer and a 2-foot-thick soil vegetative layer on the top, which includes a 6-inch-thick topsoil layer with a finished surface sloping uniformly at $3 \%$ to $5 \%$. In between the soil vegetative layer and the drainage layer, the cover system has a thin geotextile filter layer. The filter layer prevents migration of fine particles from the top soil vegetative layer to the underlain layers and, thereby, inhibits clogging the drainage layer. 


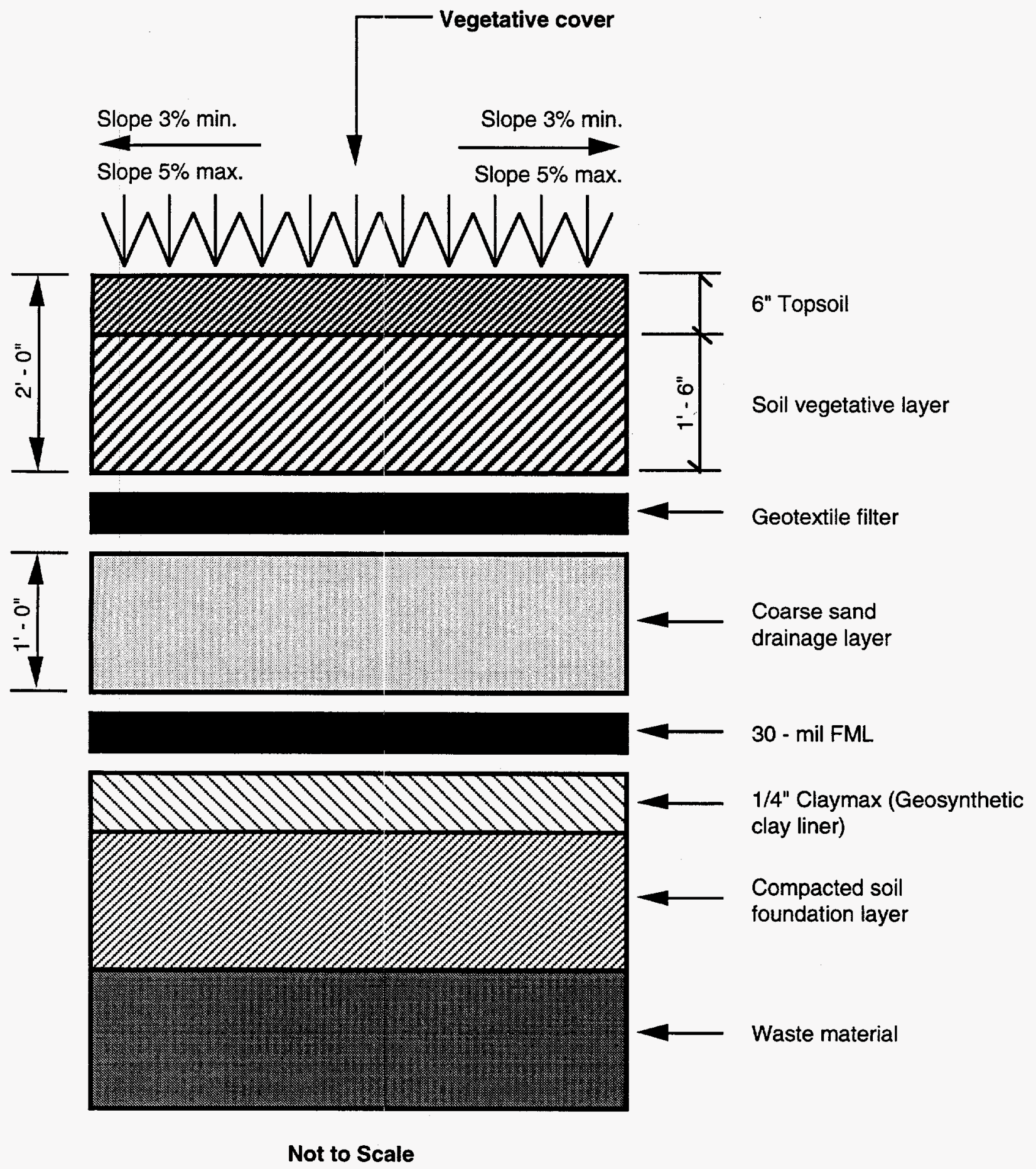

Figure 2-1. Cover system utilizing Claymax ${ }^{\circledR}(\mathrm{GBM})$ and 30-mil FML 


\subsubsection{Cover System 2 - Cover System Utilizing Bentomat $®$ and a 30- mil FML}

The cover system depicted in Figure 2-2 is the same as Cover System 1, except that the 1/4inch-thick Claymax ${ }^{\circledR}$ sheet is replaced by $1 / 4$-inch-thick Bentomat ${ }^{\circledR}$ sheet.

\subsubsection{Cover System 3 - Cover System Utilizing Gundseal@}

Figure 2-3 illustrates this cover system. This system is similar to Cover System 1 except that the 1/4-inch thick Claymax sheet, along with 30-mil FML are replaced by 1/4-inch-thick Gundseal $\circledast$ sheet. Unlike Claymax ${ }^{\circledR}$ and Bentomat $\circledast$, Gundseal $\otimes$ is a composite clay liner consisting of a layer of sodium bentonite clay adhered to a 30 -mil, high-density polyethylene (HDPE) liner. Therefore, an additional 30-mil FML is not required in this cover system design. The HDPE liner component of Gundseal $B^{\circledR}$ is manufactured in thicknesses other than 30-mil.

\subsubsection{Cover System 4 - Cover System Utilizing 120-mil High Density Polyethylene Liner}

This cover system is presented in Figure 2-4. The system is similar to Cover System 1 except that the 1/4-inch-thick Claymax $\otimes$ sheet and 30-mil FML are replaced by a single 120 -mil sheet of flexible membrane liner.

\subsubsection{Cover System 5 - Cover System Utilizing 1/4-inch Thick Hot Sprayed or Emulsified Asphalt}

Figure 2-5 illustrates the design of this cover system. The design for this cover system is similar to Cover System 1 except that the 1/4-inch-thick Claymax $®$ sheet is replaced by a $1 / 4$ inch thick hot sprayed or emulsified asphalt membrane. The membrane is prepared in situ by sprinkling water over the prepared foundation layer and then spraying hot asphalt under pressure using spray bars. The hot asphalt applied at the rate of 1.5 gallons per square yard (three passes of 0.5 gallon per square yard) yields a desirable "ply" affect.

\subsubsection{Cover System 6 - Cover System Utilizing Reinforced Sprayed Asphalt}

This cover system, shown in Figure 2-6, is similar to Cover System 5 except that the 1/4-inchthick hot sprayed asphalt membrane is reinforced with a thin layer of geotextile membrane fabric.

\subsubsection{Cover System 7 - Cover System Utilizing Compacted Kaolin (Offsite) Clay and 30-mil FML}

This cover system, shown in Figure 2-7, utilizes a 2-foot-thick compacted kaolin clay layer to provide a minimum of $1 \times 10^{-7} \mathrm{~cm} / \mathrm{s}$ permeability as recommended by the EPA, in a multilayer cover system. The clay layer is covered by a 30-mil FML. The rest of the design for this cover system is similar to Cover System 1. 


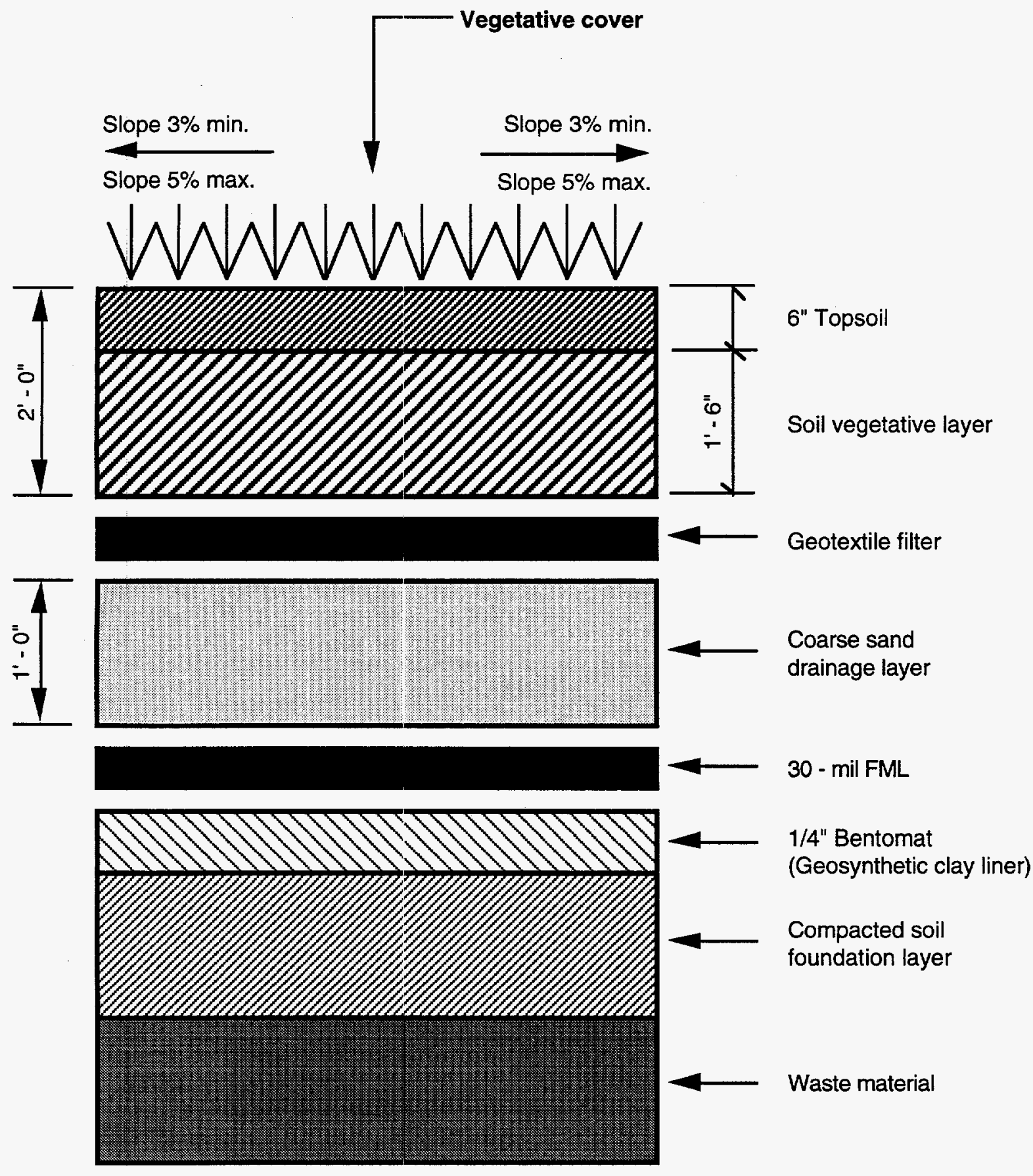

\section{Not to Scale}

Figure 2-2. Cover system utilizing Bentomat ${ }^{\circledR}(\mathrm{GBM})$ and $30-$ mil FML 
Vegetative cover
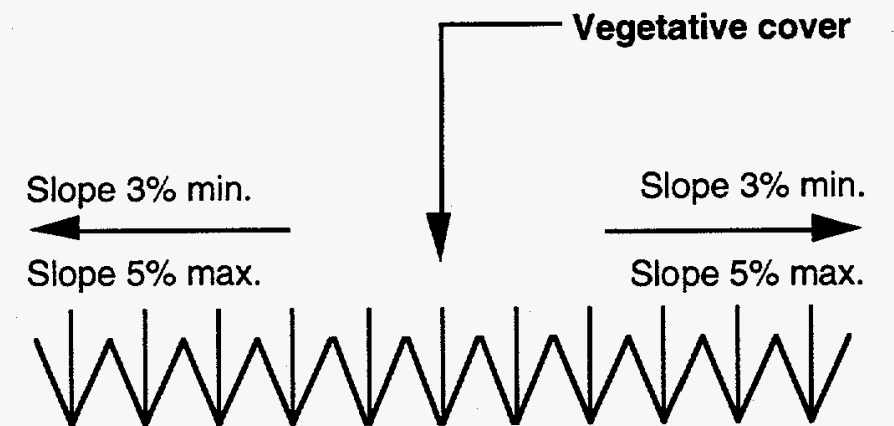

1
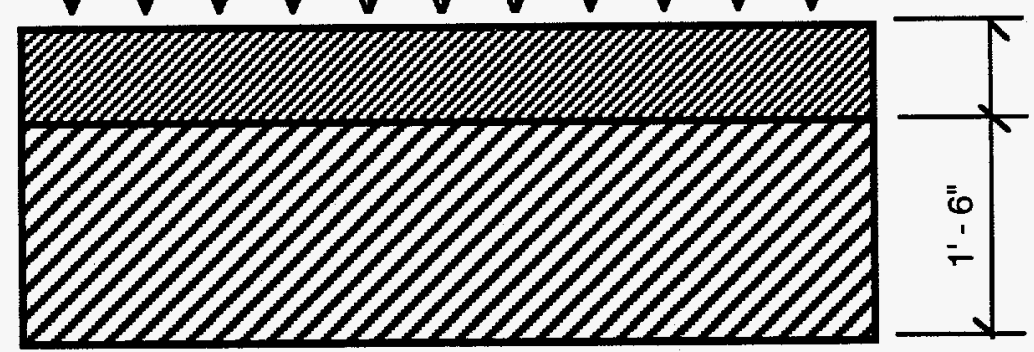

6" Topsoil

Soil vegetative layer

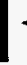
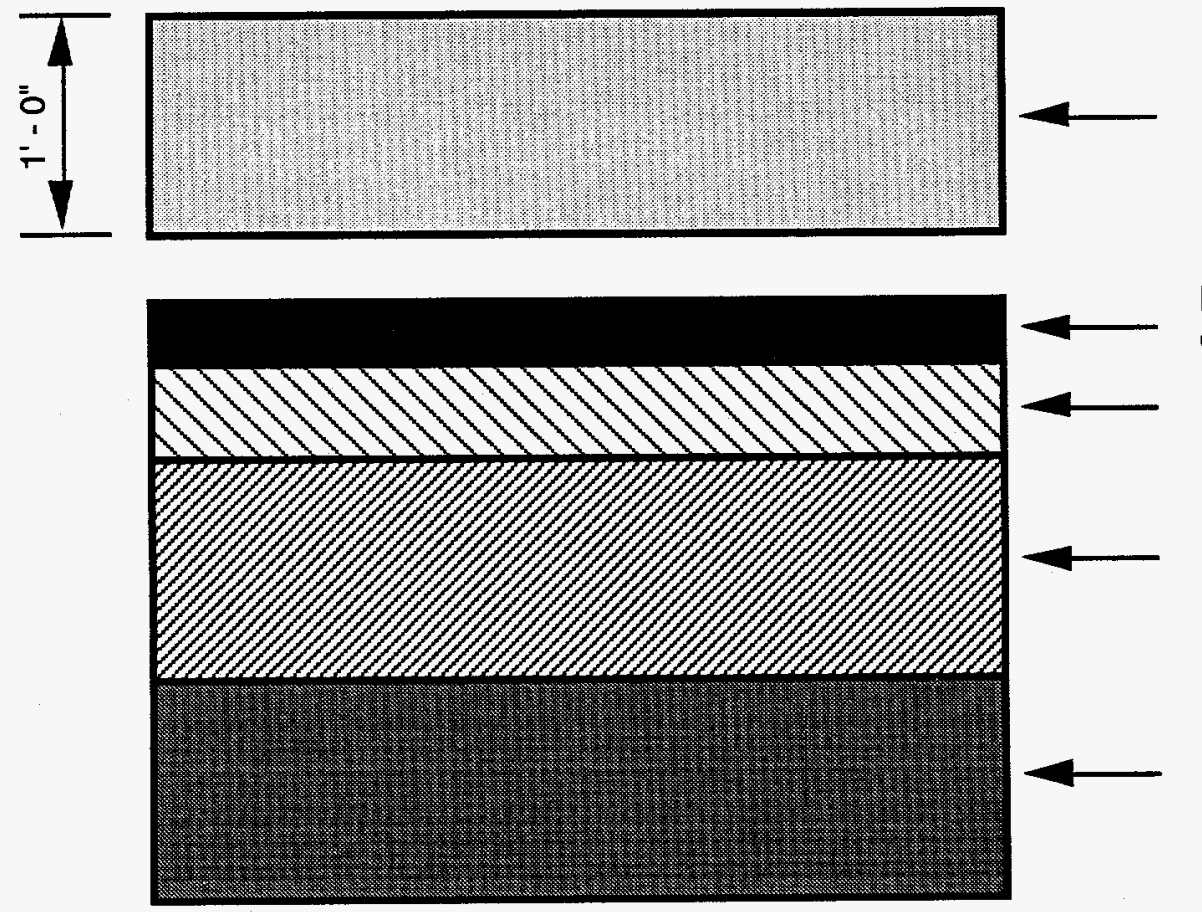

Waste material

\section{Not to Scale}

Figure 2-3. Cover system utilizing Gundseal $®(\mathrm{GBM})$ 

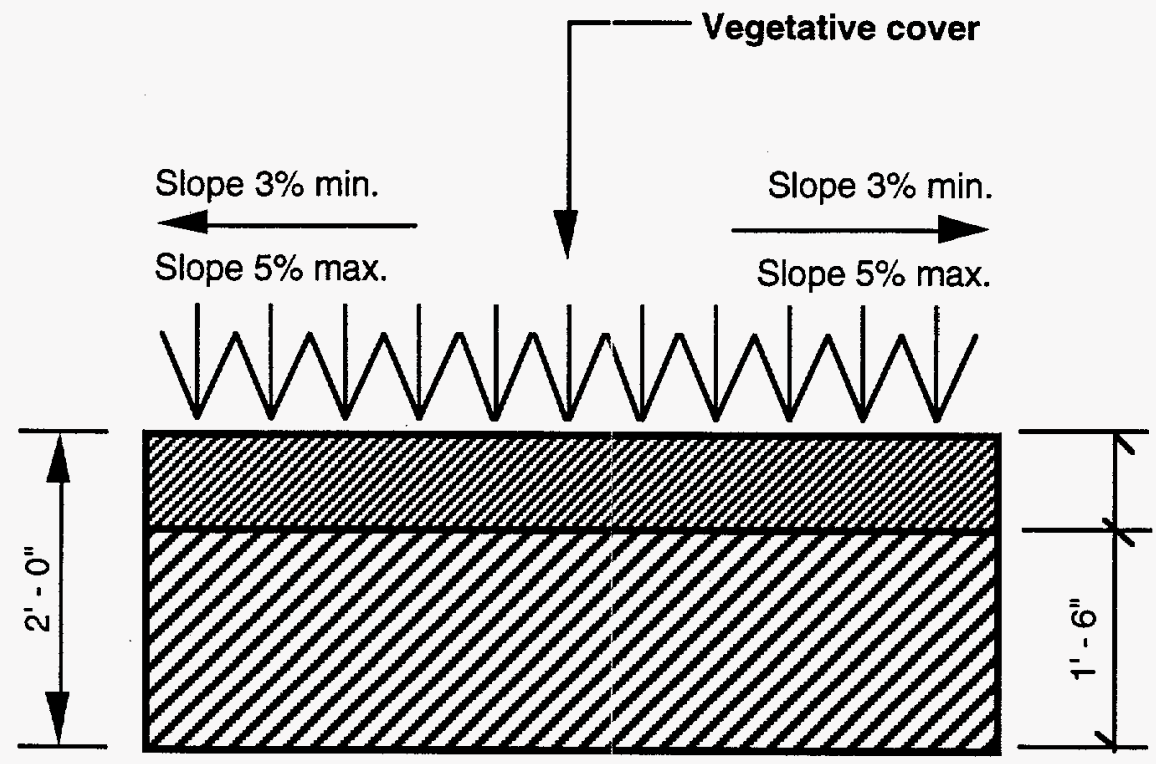

\section{6" Topsoil}

Soil vegetative layer

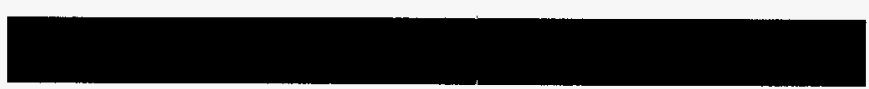

$\longrightarrow$
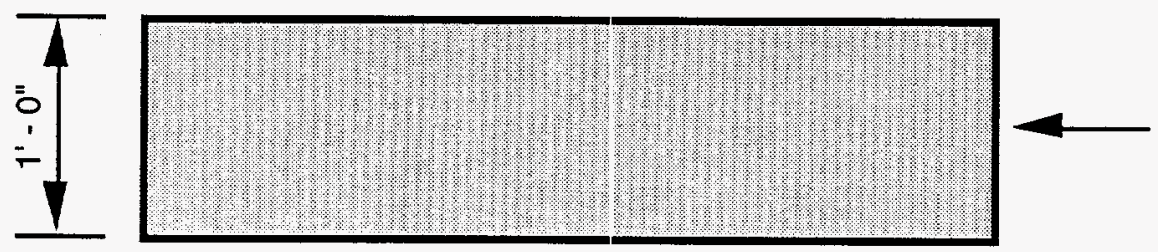

\section{Coarse sand} drainage layer

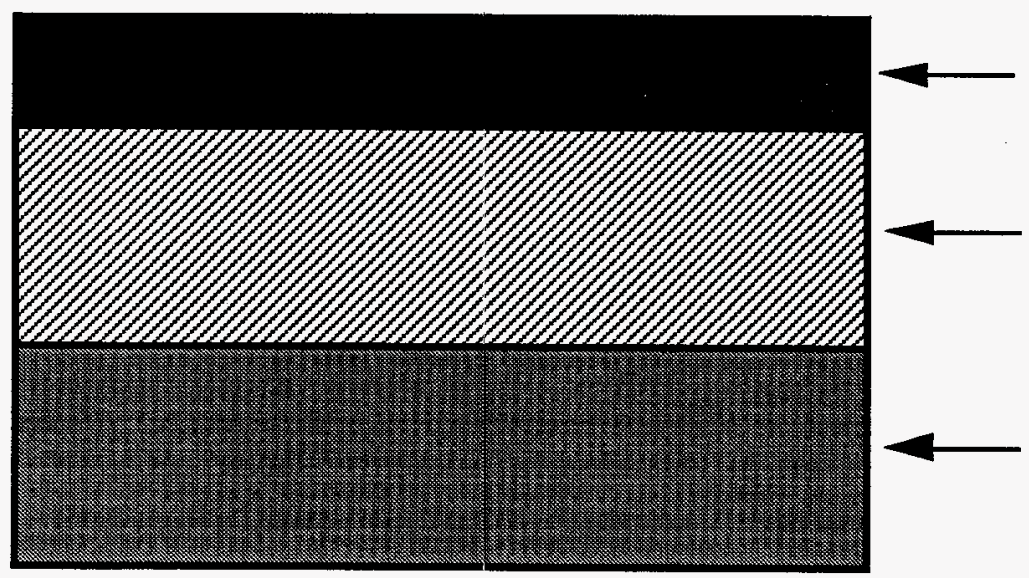

120 - mil flexible membrane liner

Compacted soil foundation layer

\section{Not to Scale}

Figure 2-4. Cover system utilizing 120-mil flexible membrane liner (FML) 

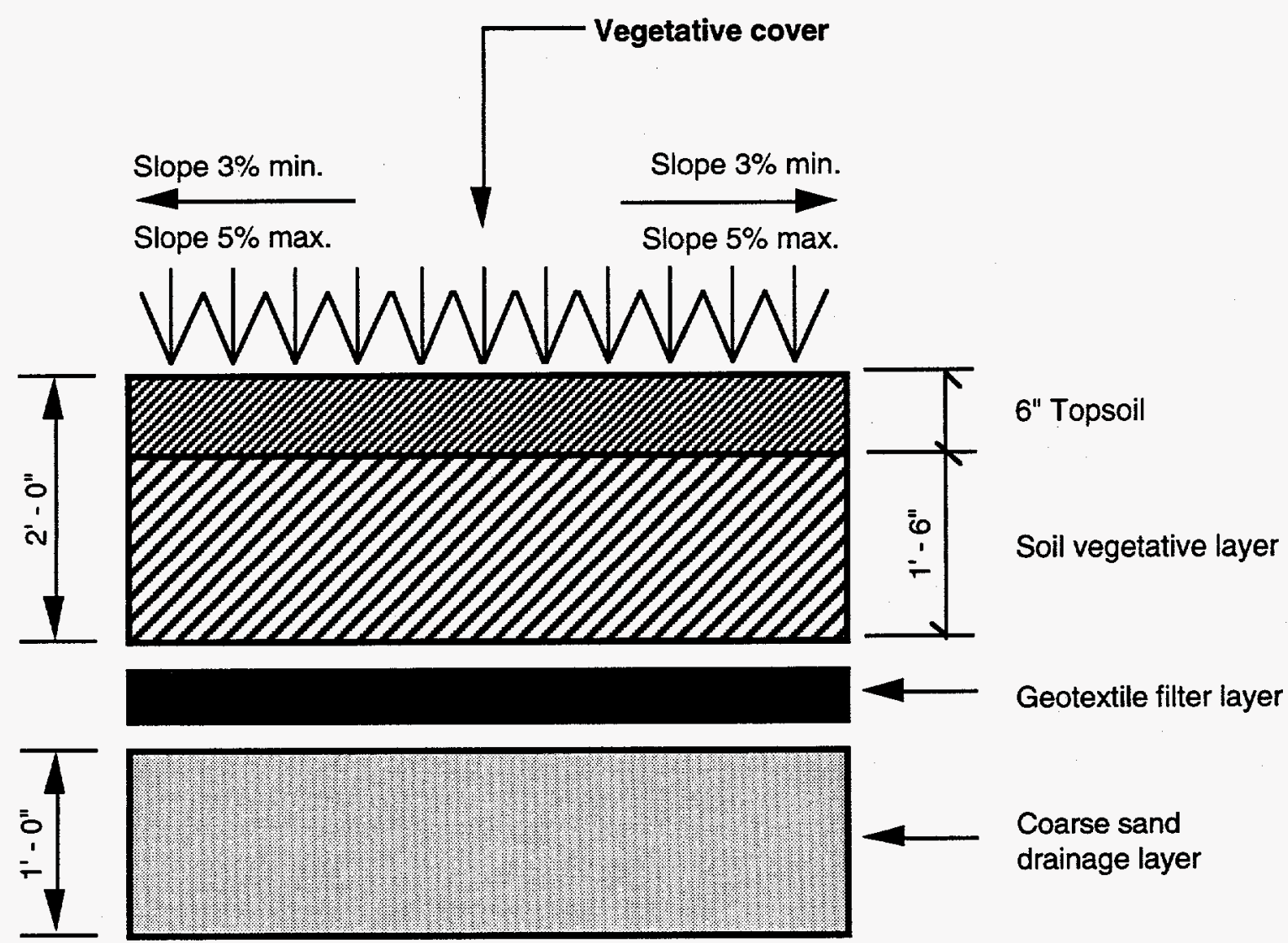

Coarse sand
drainage layer

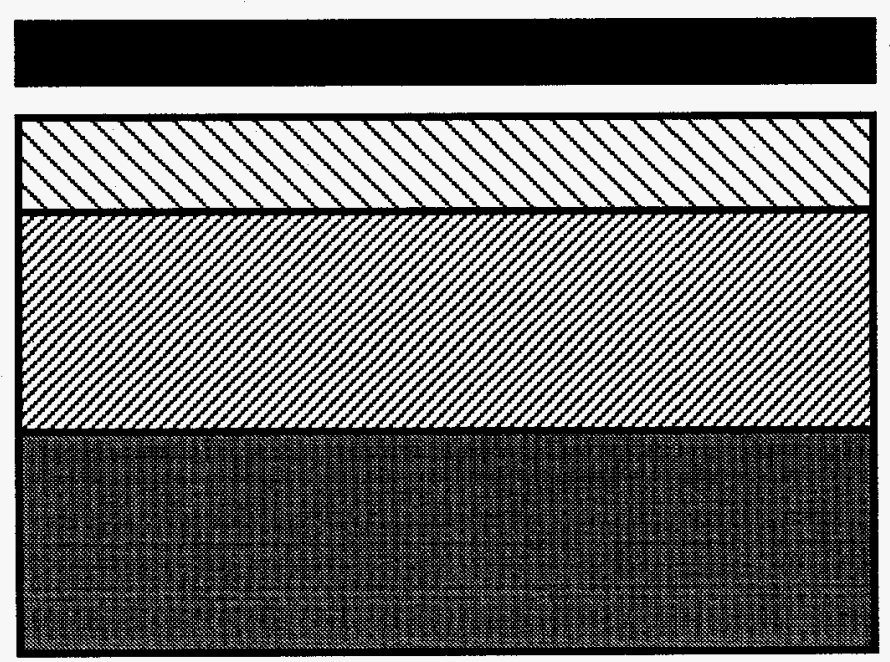

$\longrightarrow 30-$ mil FML

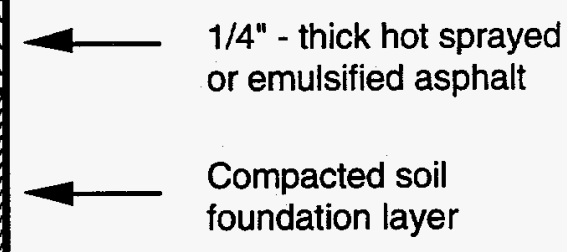

Not to Scale

Figure 2-5. Cover system utilizing hot-sprayed or emulsified asphalt 


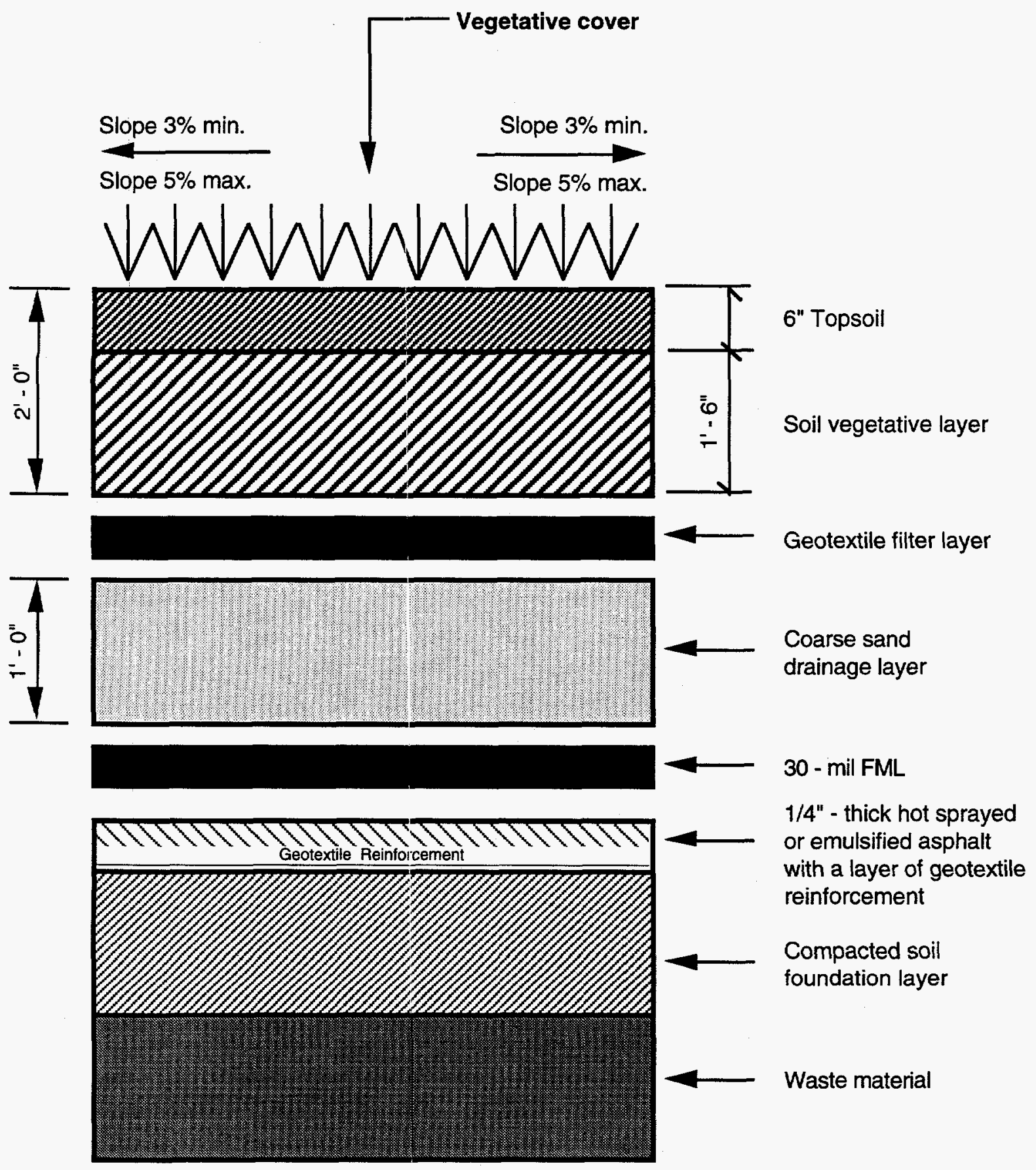

Not to Scale

Figure 2-6. Cover system utilizing reinforced sprayed asphalt 


\section{Vegetative cover}

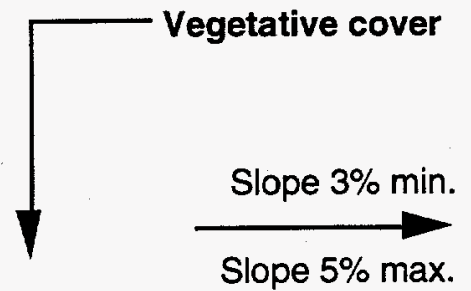

Slope $5 \% \max$.

Slope $5 \% \max$.

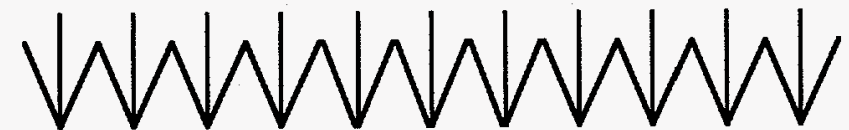

1
5
1
1
1
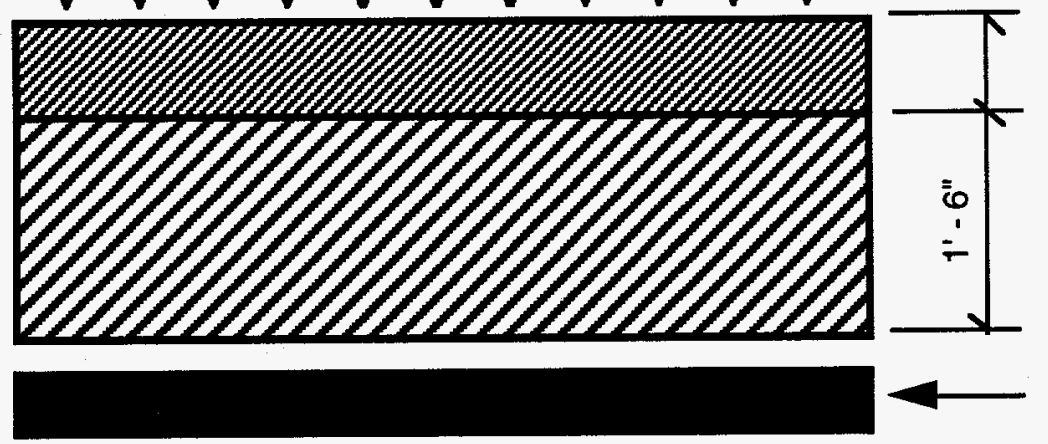

Geotextile filter
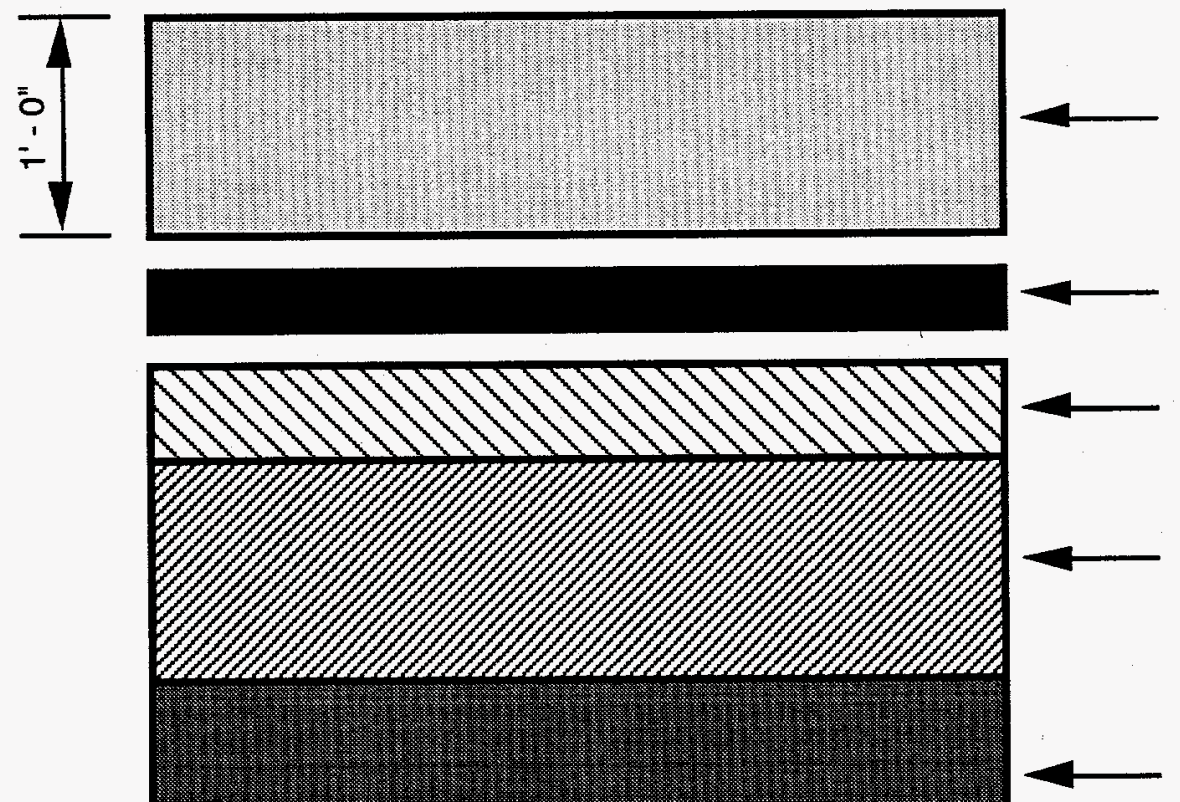

Compacted soil

foundation layer

Coarse sand

drainage layer

$30-$ mil FML

Compacted clay layer (2' - 0")

Waste material

\section{Not to Scale}

Figure 2-7. Cover system utilizing offsite/onsite compacted clay and 30-mil FML 


\subsubsection{Cover System 8 - Cover System Utilizing Compacted Onsite Sandy Clay and 30-mil FML}

This cover system is similar to the cover system shown in Figure 2-7 except that the 2-foot compacted kaolin clay layer is replaced by a 2 -foot-thick compacted onsite sandy clay layer, which is blanketed by a 30-mil FML, to provide a minimum of $1 \times 10^{-7} \mathrm{~cm} / \mathrm{s}$ permeability.

\subsubsection{Cover System 9 - Cover System Utilizing Soil Cement and 30- mil FML}

This cover system is shown in Figure 2-8. In this cover system, the 1/4-inch-thick Claymax sheet, as shown in cover system 1 , is replaced by a 3 -foot-thick soil-cement layer. The soilcement mixture is placed in 6-inch to 8-inch lifts by spreaders and compacted to achieve $95 \%$ $98 \%$ standard proctor density, and blanketed by a 30 -mil FML to provide a permeability of $1 \times 10^{-7} \mathrm{~cm} / \mathrm{s}$ or more.

\subsubsection{Cover System 10 - Cover System Utilizing Bentonite Soil Additive and 30-mil FML}

This cover system is shown in Figure 2-9. The cover design is similar to Cover System 9 except that the 3 -foot-thick soil-cement layer is replaced by a 12-inch-thick soil and soil bentonite additive layer compacted to at least $95 \%$ of the standard proctor density and blanketed with a 30 -mil FML to provide a minimum permeability of $1 \times 10^{-7} \mathrm{~cm} / \mathrm{s}$.

\subsubsection{Cover System 11 - Cover System Utilizing Asphalt Concrete Hydraulic Barrier and 30-mil FML}

This cover system is shown in Figure 2-10. In this cover design, the 1.5-foot-thick soil vegetative layer and the 6-inch top soil layers, as provided in Cover System 1, are replaced by a 2.5-inch-thick asphalt concrete binder course (over 1-foot-thick coarse sand drainage layer) and a 4-inch-thick hydraulic asphalt concrete layer. To make the cover water tight, a 1/8-inchthick asphalt mastic seal is applied and sprayed with an asphalt cement sealant at the rate of 0.25 gallons per square yard.

\subsubsection{Cover System 12 - Cover System Utilizing Poured-in-Place Concrete Slab and 30-mil FML}

This cover system (Figure 2-11) is similar to Cover System 11 except that the top layers (2.5inch-thick asphalt concrete binder course and 4-inch-thick hydraulic asphalt concrete cover) are replaced by a 4-inch thick reinforced concrete slab with watertight slab joints, as shown in Figure 2-11. 


\section{Vegetative cover}
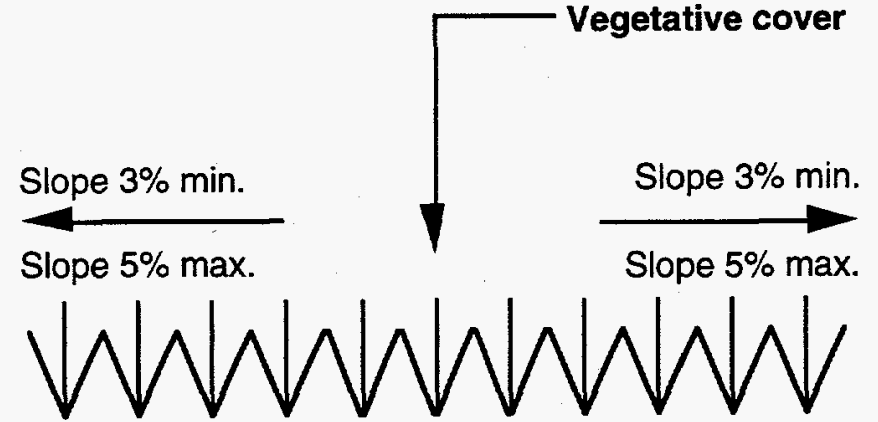

1
0
0
$i$
1
1
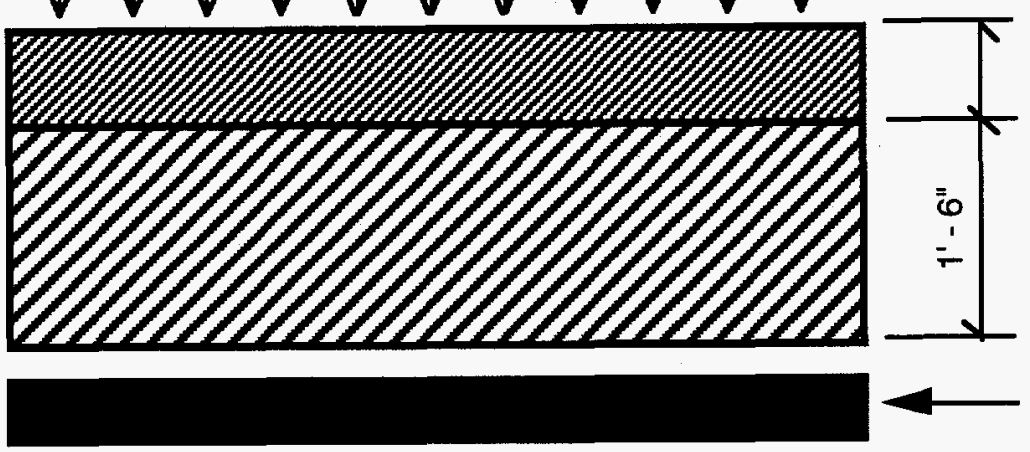

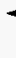
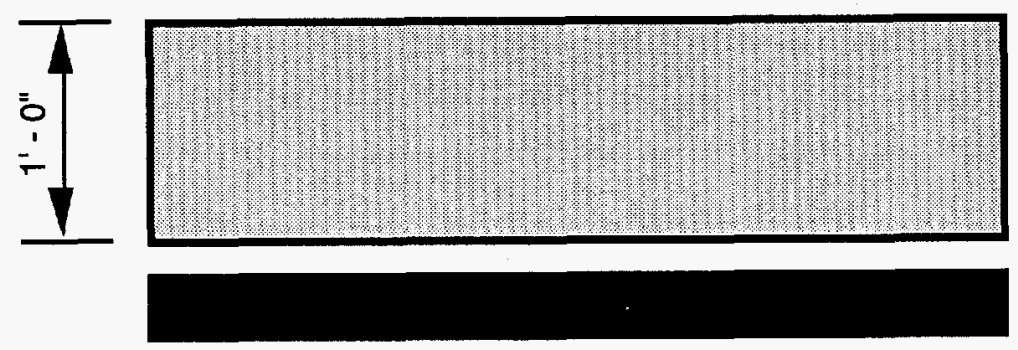

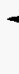
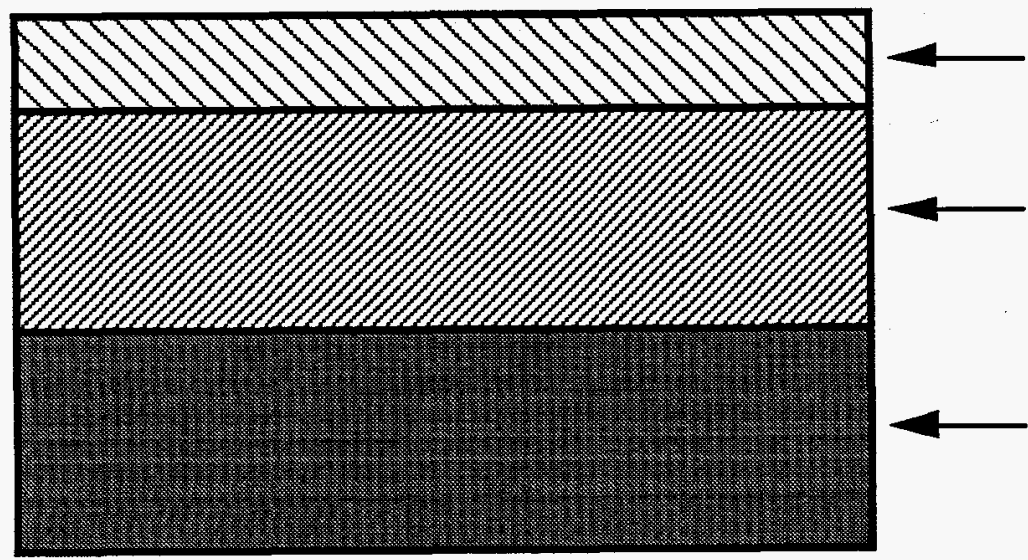

\section{Not to Scale}

Figure 2-8. Cover system utilizing soil cement and 30-mil FML
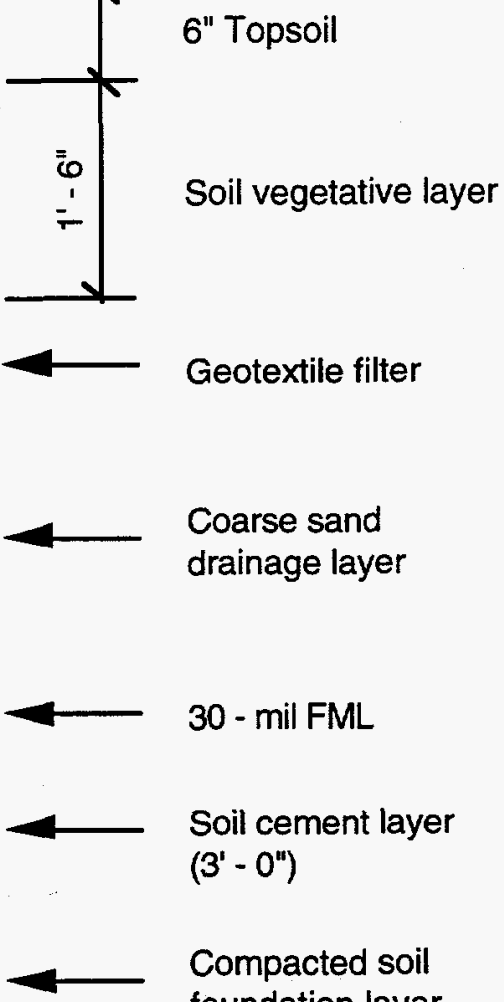

Soil vegetative layer

Geotextile filter

Coarse sand drainage layer

30 - mil FML

Soil cement layer $\left(3^{\prime}-0^{\prime \prime}\right)$

Compacted soil foundation layer

\section{Waste material}




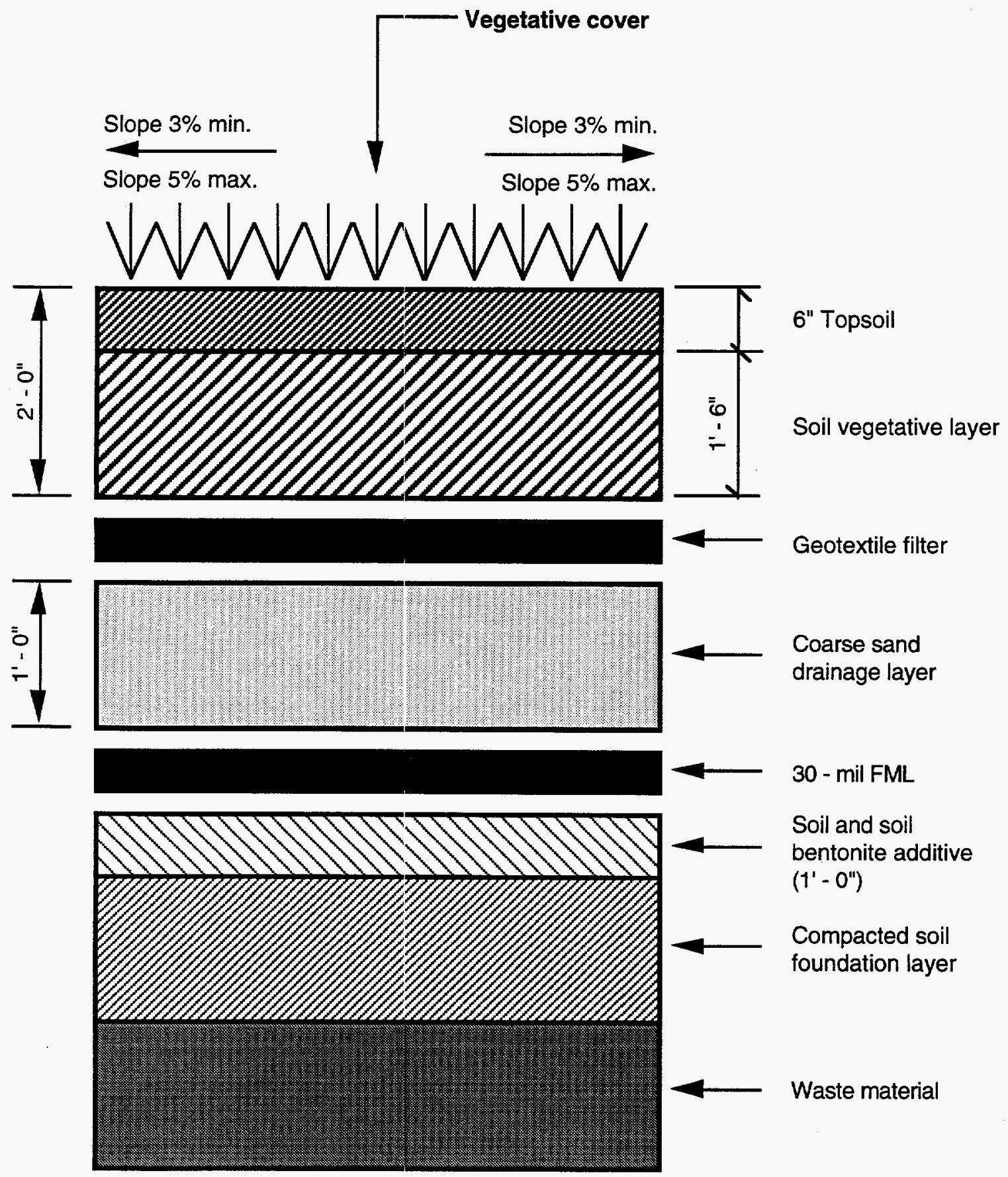

Not to Scale

Figure 2-9. Cover system utilizing bentonite soil additive and 30-mil FML 


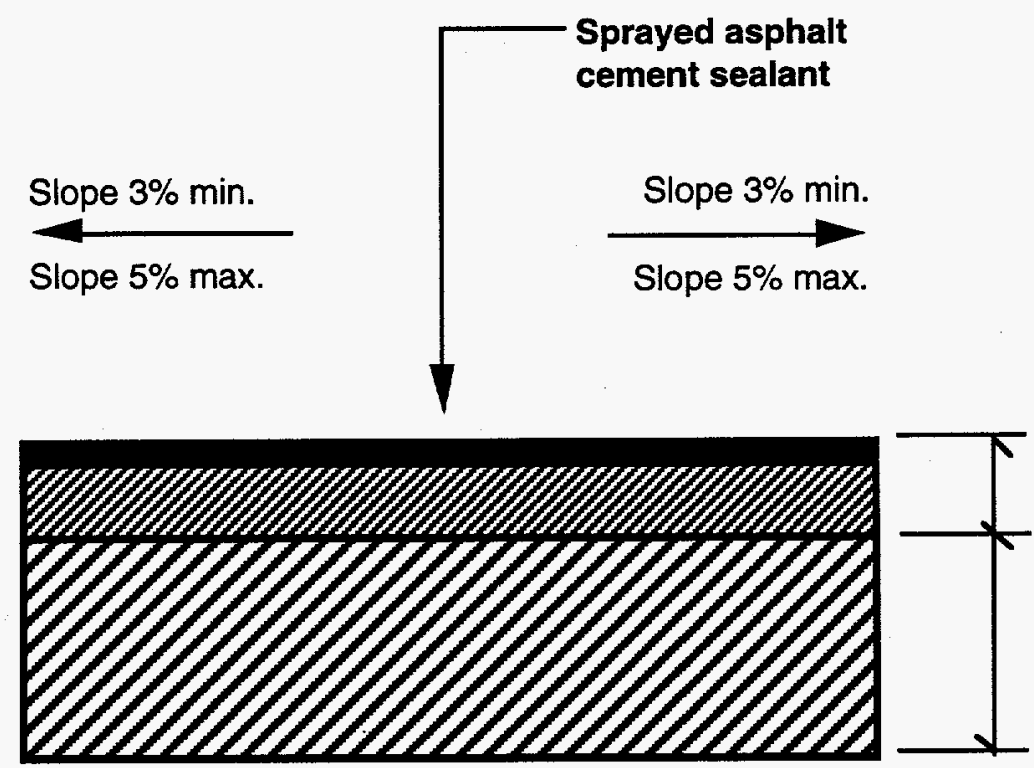

4" min. hydraulic asphalt concrete

$21 / 2^{\prime \prime}$ asphalt concrete binder course
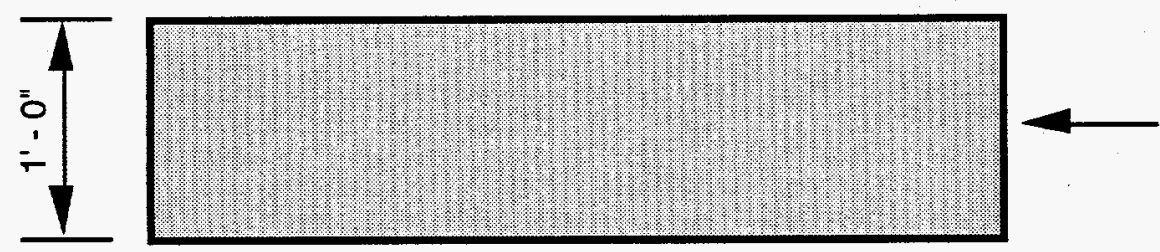

1' - 0" Coarse sand drainage layer
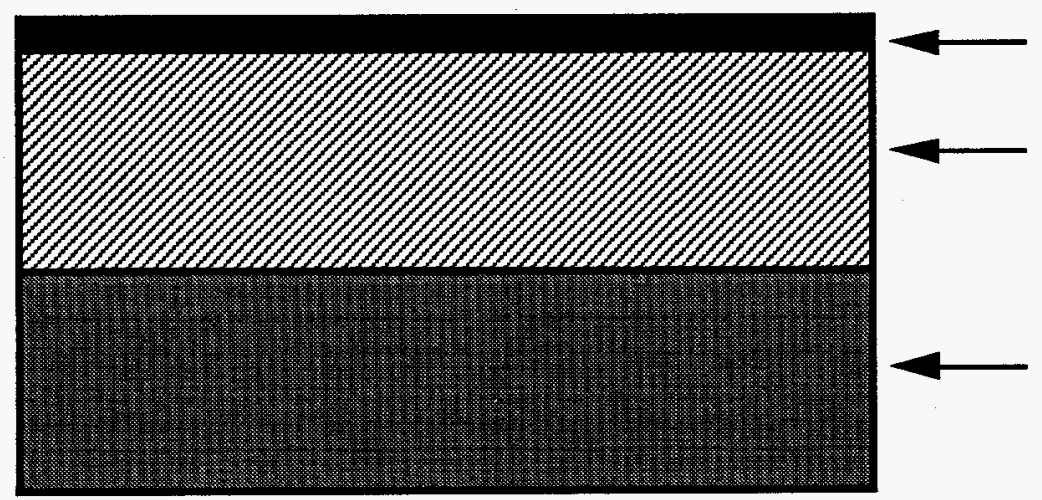

30 - mil FML

Compacted soil foundation layer

\section{Not to Scale}

Figure 2-10. Cover system utilizing hydraulic asphalt concrete and 30-mil FML 


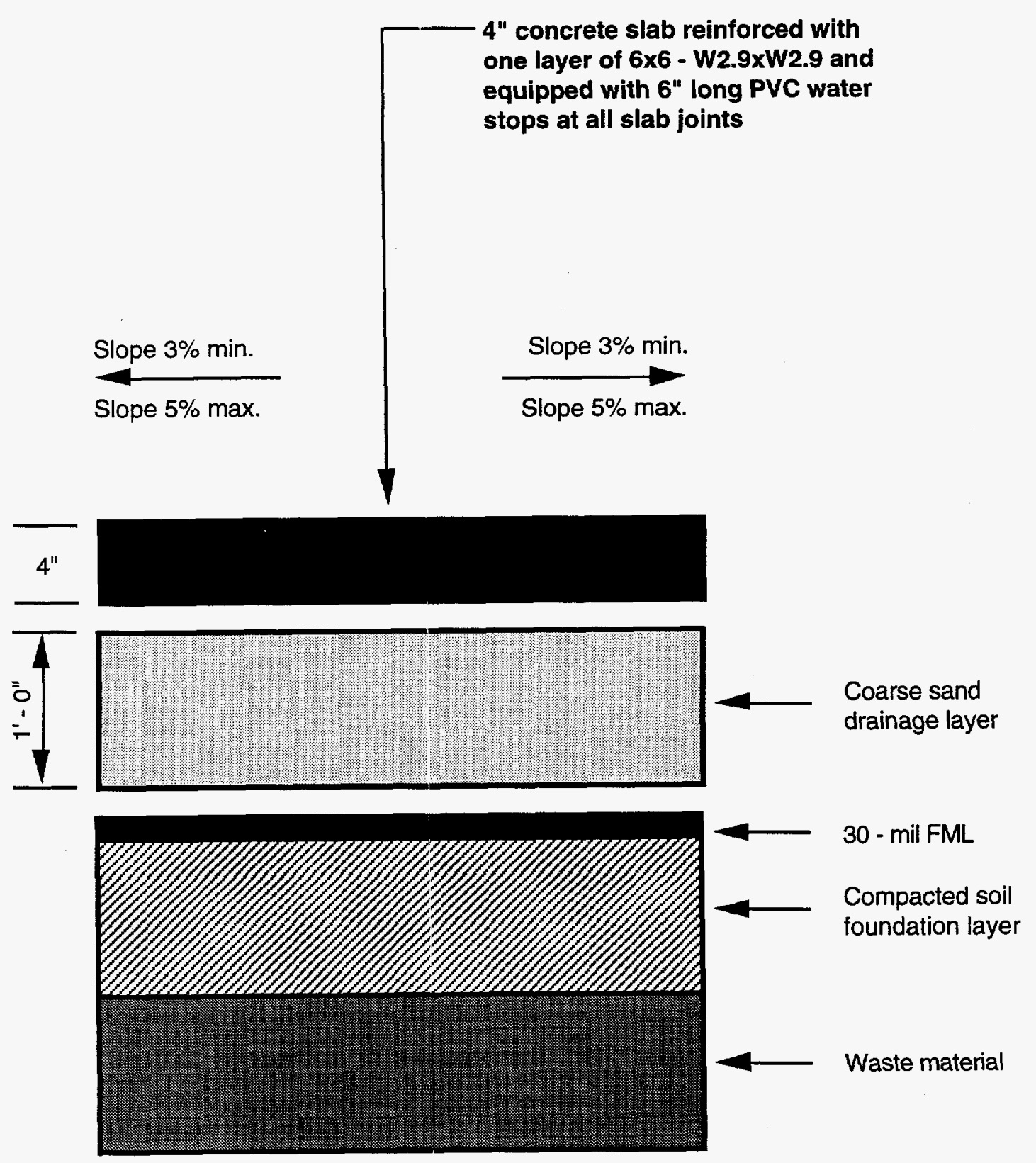

\section{Not to Scale}

Figure 2-11. Cover system utilizing poured-in-place reinforced concrete slab and 30-mil FML 


\subsection{Cost Estimation Approach}

\subsection{Cost Data Sources}

The standard engineering cost-estimating methodologies are not sufficiently accurate in estimating actual expense costs, primarily because hazardous waste sites are unique in their characteristics and there are a number of uncertainties in the eventual effectiveness of barrier materials as final cover systems. All efforts have been made to come up with cost estimates that represent the site closure projects. However, the costs documented in this report should not be misconstrued as actual project costs, but as comparative costs between given barrier materials. Since there is no single standard engineering cost-estimating source, the supporting cost data utilized in this report have been derived from various sources. The major cost data sources include the following:

- record files of SRS closure projects recently completed, as well as composite cover systems being used

- vendors, suppliers, and manufacturers of geosynthetic clay materials

- published literature containing cost data pertaining to similar projects

- Means Guide for Construction Cost Data (1992)

- Engineering News Record construction cost index

- personal contacts with professionals involved in environmental restoration and waste site closure management

A number of meetings were held with ER closure professionals, WSRC Project Management, Bechtel Construction, and managers of the Barnwell County Low-Level Radioactive Disposal Facility. The following information was obtained through these meetings:

- Barnwell County Low-Level Radioactive Disposal Facility, Barnwell, South Carolina - This facility, operated and managed by Chem-Nuclear, receives low-level radioactive waste. A portion of the facility has recently been closed and an interview was conducted with the resident engineer responsible for the site closure. Cost data were obtained by reviewing the original bids Chem-Nuclear received from various vendors for the site closure. Actual cost data for the closure cap were reviewed, and the cost data and related information are presented in Table 3-1. According to these cost data, the cost per square foot of a closure cap is approximately $\$ 5.50$.

- Met Lab Closure (SRS) - Meetings were held with WSRC ER closure professionals to obtain cost data. For the benefit of this report, monthly cost data were reviewed. Additionally, engineers from Project Management and Bechtel Construction, who were responsible for overseeing the closure, were interviewed. The collected information has been incorporated into the cost estimating effort.

- Mixed Waste Management Facility (SRS) - Managers and the cognizant engineers from WSRC ER closure were consulted to obtain cost data for this project. Because cost figures were estimates rather than actual costs for the closure, the cost data could not be utilized. Attempts were made to obtain comprehensive information on the cost data from Project Management; however, the available information was only in the form of lumpsum billing by the vendor(s). 
Table 3-1. Barnwell County Low-Level Radioactive Waste Disposal Facility, Barnwell, South Carolina

Project area:

Time to construct cap:

Material used for

foundation layer:

Cost for the cap:

\section{Cap specifics:}

Overall area of cap:

Volume of compacted soil:

Cost to move soil to the site:

Cost of mobilizing equipment:

Import sand:

Foundation clay:

Top soil:

QA

Construction testing of soil:

Geosynthetic liner testing and verification: $\$ \$ 2,000$

QA report and certification:

Preconstruction evaluation:

Soil barrier testing (compaction):

Approximate total QA cost:

Cost per square foot of cap:

\section{3 acres} preparation)
About three months (excluding foundation layer

Soil at the site has a $1 \times 10^{-5} \mathrm{~cm} / \mathrm{sec}$ permeability, and clay contents are less than $20 \%$. Approximately 560,000 cubic feet of this soil was used for preparing the foundation (1-foot-thick compacted soil layer).

$\$ 2.8$ - $\$ 3$ million, the cap cost includes the cost for the 40-mil HDPE liner (@32 $q / \mathrm{sq} \mathrm{ft}$ installed). The additional major components of the cover systems include a Claymax layer, a 1-foot-thick sand layer, a 2-foot-thick vegetative layer, and 6 inches of top soil.

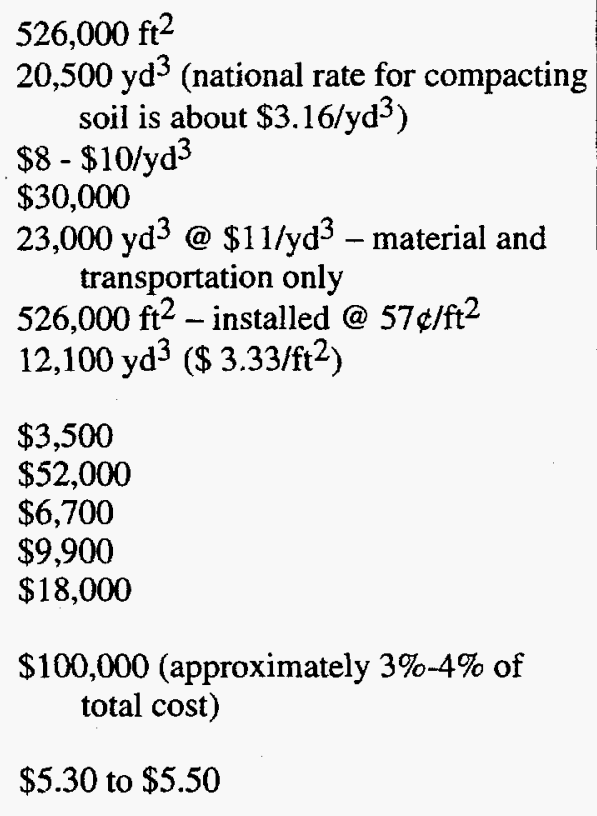

- F-, M-, and H-Area Seepage Basins (SRS) - Useful cost data for these projects were not available. These projects did not require the vendor to itemize the cost for individual components of the closure caps.

- Geosynthetic Clay Materials - Telephone contacts were made with the manufacturer representatives of geosynthetic materials. The information received is summarized in Table 3-2. 
Table 3-2. Geosynthetic Clay Liner Materials

\begin{tabular}{|c|c|c|c|c|}
\hline Material & $\begin{array}{l}\text { Contact } \\
\text { Person }\end{array}$ & Telephone No. & $\begin{array}{c}\text { Delivered } \\
\text { Material Cost } \\
\left(\mathrm{ft}^{\mathbf{2}}\right)\end{array}$ & $\begin{array}{l}\text { Installation } \\
\left.\text { Cost* }^{*} \mathbf{y d}^{3}\right)\end{array}$ \\
\hline Claymax ${ }^{\circledR}$ & Greg Scott & (404) $321-5316$ & $40-50 \not$ & $6-11 \varnothing$ \\
\hline Bentomat $(8)$ & Bob Trouger & (708) $392-5800$ & $40-50 \not c$ & $5-15 \varnothing$ \\
\hline Gundseal ${ }^{\circledR}$ & Scott Ortolon & (713) 443-8564 & $45-50 \not \varnothing$ & $20 \not \varnothing$ \\
\hline
\end{tabular}

*The installation cost does not include the cost for preparing the bed. None of the manufacturers could provide information on quality assurance (QA) cost data.

Source: References 3, 4, and 5

\subsection{Cost Parameters}

The total cost of an environmental closure project is influenced by the characteristics of the disposed waste materials and the geological features of the site. For the purpose of this report, the following parameters are considered for cost estimating:

- $\quad$ size of the cover system

- type of barrier material(s)

- material quantities

- unit price/cost of material(s), including transportation cost (if applicable)

- QA/QC cost (i.e., material inspectors)

- health and safety cost

- contingency costs

- engineering /administrative costs

- operations and maintenance postclosure costs, such as groundwater sampling and analysis, closure cap inspection, vegetative cover maintenance, fence and warning signs maintenance, subsidence monitoring, and repairs resulting from failures due to subsidence

- auxiliary costs (i.e., erosion control, decontamination, data analysis and report writing, etc.)

\subsection{Cost Assumptions}

It is assumed that each waste site will be covered by leaving the hazardous waste in place. For the purpose of calculating the total project costs, the costs were divided into three categories:

- site preparation costs

- closure costs (cost for the construction of a cover system)

- postclosure costs (O\& M costs)

For each of these categories the following assumptions were made:

- Site Preparation

- Clearing and grubbing the site: Assume the limit of construction will be 100 feet from the edge of the waste site. 
- Precontouring the site: This includes surface water management, erosion control during the construction process, removing and stockpiling the topsoil, and grading laydown areas for the construction materials and facilities. Assume an impacted area equivalent to the area outside of the waste site is bounded by construction limits.

- Erosion control measures: This includes temporary ditches, dikes, silt fences, and berms for runoff diversion. Assume that $75 \%$ of the site perimeter will have a silt fence with steel posts at 10 feet on centers, with a filter fabric 2' 8" high. Fabric will be supported at the top and bottom by \#10 gauge wire. The sites larger than five acres contain sedimentation basins.

- Access road: Assume there is a 20-foot- wide gravel haul road with a length equal to $50 \%$ of the site perimeter; include two 15 -inch-diameter RCP culverts, each 32 feet in length.

- Decontamination pad: Assume there is a 35' $-0^{\prime \prime}$ x $35^{\prime}-0^{\prime \prime}$ pad with a 6'-0" x $35^{\prime}-0$ " $x$ 4'-0" deep washwater collection ditch. The pad will be constructed from bottom to top as follows: 3-inch-thick sand base; 60-mil FML geomembrane liner; 3 inches of sand: Geotextile Fabric: 9 inches - 10 inches granular material. The ditch will have a 3 -inch-thick sand base covered with a 60 -mil FML. The geomembrane will be held in place by sand bags at the water collection ditch.

- Support facilities: Assume that the following will be required:

- construction trailer

- toilet, portable water supply, temporary power and telephone

- Sedimentation basins:

- There is one basin for 10 - and 20 -acre sites.

- There are two basins for 40 -acre sites.

- There are four basins for 80 -acre sites.

- Closure Costs

- Finish grading of the cover cap and site for final closure topography: Assume grading will include $75 \%$ of the site area.

- Drilling and installing monitoring wells (groundwater contamination monitoring): Assume there are four groundwater monitoring wells all 100-feet deep. One well will be placed hydraulically upgradient and three wells will be placed hydraulically downgradient for sites up to 5 acres. The number of wells for sites 10 acres and larger were assumed to be from 8 to 30 , for sites 10 acres and 80 acres sites, respectively. Materials include stainless steel casing, screens, pumps, tubing, caps, and locks. The well is 2 inches in diameter.

- Erection of security fence: Assume the security fence will be 20 feet away from the edge of the perimeter drainage ditch (refer to Figures 3-1 and 3-2). Assume it is a 6'0 " high chain link fence with 2 inches of mesh, steel, and a galvanized No. 6 gauge with three strands of barb wire at the top for a total height of 8 feet. Posts will be 2 inches in diameter at $10^{\prime}-0^{\prime \prime}$ o.c. The top and bottom will be made of No. 7 gauge aluminized, coiled steel wire.

- Security gate: Assume there will be one 8- $\mathrm{ft}$ x 20 - $\mathrm{ft}$ chain link gate for sites up to 10 acres and two gates for sites larger than 10 acres.

- Drainage ditch excavation: Assume there is a drainage ditch around the entire cover (refer to Figures 3-1 and 3-2).

- Clean up and demobilize: Assume the cleanup and demobilization is $5 \%$ of the total direct costs.

- Warning signs: Assume there are four 18-in x 24-in signs for sites up to 5 acres.

- Survey the final cover: Assume a professional land surveyor and surveying technician charges $\$ 75 /$ hour for 16 hours. This equals $\$ 1,200$ for each site.

- Escalation for 1994: Assume it is $1.9 \%$ for direct labor costs and $2 / 5 \%$ for material costs. 
- Location factor: Assume this is $40 \%$ of the total labor cost plus escalation.

- Indirect Costs

- Certification of final closure: Assume this cost will be 3\% of the total direct cost for sites up to 5 acres. For larger sites, the certification fee assumed is less than $3 \%$.

- Health and safety: Assume these costs will be 5\% of the total direct cost for sites up to 5 acres. For larger sites, the cost is assumed at less than $5 \%$.

- Scope contingency: Assume this cost is $10 \%$ of the total direct cost for sites up to 5 acres. For larger sites, the cost is assumed at less than $10 \%$.

- Administrative and legal: Assume this cost is $10 \%$ of the total direct cost for sites up to 5 acres. For larger sites, the assumed cost will be less than $10 \%$.

- Engineering and services: Assume this cost is $20 \%$ of the total direct cost for sites up to 5 acres. For larger sites, the assumed cost will be less than $20 \%$.

- Craft support: Assume this cost is $20.8 \%$ of the total man-hours @ $\$ 19 /$ hour.

- Field indirects on total directs: Assume this will be $46.5 \%$ of the total direct labor and $26.5 \%$ for total bulk material costs.

- Construction nonmanual: Assume this cost will be $25.2 \%$ of the total direct manhours @ \$43.68/hour.

- Project management: Assume this cost will be $8 \%$ of total direct plus total indirect costs.

- Postclosure costs/O \& M costs

- Groundwater monitoring: This includes quarterly sampling efforts, laboratory analysis of samples, and report writing. Assume this will be $\$ 225 /$ sample $x 4$ samples $x 4 /$ year $=\$ 3,600 /$ year for sites up to 5 acres. The sampling cost will increase for larger sites because of the increase in the number of monitoring wells.

- Inspection activities: Assume a registered professional engineer will visit the facility once a month for a minimum of four hours each visit. The time estimate includes travel to and from the site, inspection time, and time to draft a short report. Costs will increase for larger sites.

- Subsidence monitoring: Assume an annual survey will be conducted using conventional surveying methods (land surveying team and report). Costs will increase for larger sites.

- Maintenance of the vegetative cover: Assume there will be two mowings per year. Assume the site will be fertilized once a year. Assume there will be rodent control and erosion control and drainage maintenance.

- Maintenance of fence and signs: Assume the fence life is 30 years. Maintenance costs will depend on the site size.

- Monitoring well maintenance: Groundwater monitoring well parts, such as pumps, tubings and caps, may need replacing. The costs will increase as the size of the site increases because of the increase in the number of wells.

- Cover repair due to subsidence: The cost for the repairs resulting from subsidence were calculated based on an assumed sinkhole of 7 feet in diameter. First, the cost for a sinkhole was calculated for each barrier material by computing various quantities of materials, equipment required, and man-hours involved. Since there are no historical records for sinkhole failures for the barrier materials considered in this report, the frequency of repairs for each material was assumed by the best engineering judgment. Frequencies of repair events were assumed for various waste site sizes ranging from two for 0.1 -acre sites (two sinkholes resulting from subsidence over a period of 30 years, first sinkhole after 24 years and second sinkhole over the remaining 6 years) to 51 for 80 -acre sites (five sinkholes during first six years, six during next six years, 10 during 13 th through 18 th years, 12 during 
19th through 24 th years, and 18 during the 24th through 30 th year). The total repair cost over the 30-year period was calculated. Finally, the total repair cost for each barrier material was converted to the present annual cost assuming a $5 \%$ discount rate. Tables C-1 (Appendix C) presents the sinkhole repair cost for each barrier material and Table C-2 (Appendix C) presents the assumed frequencies of repair events for each waste site size considered for economic analysis.

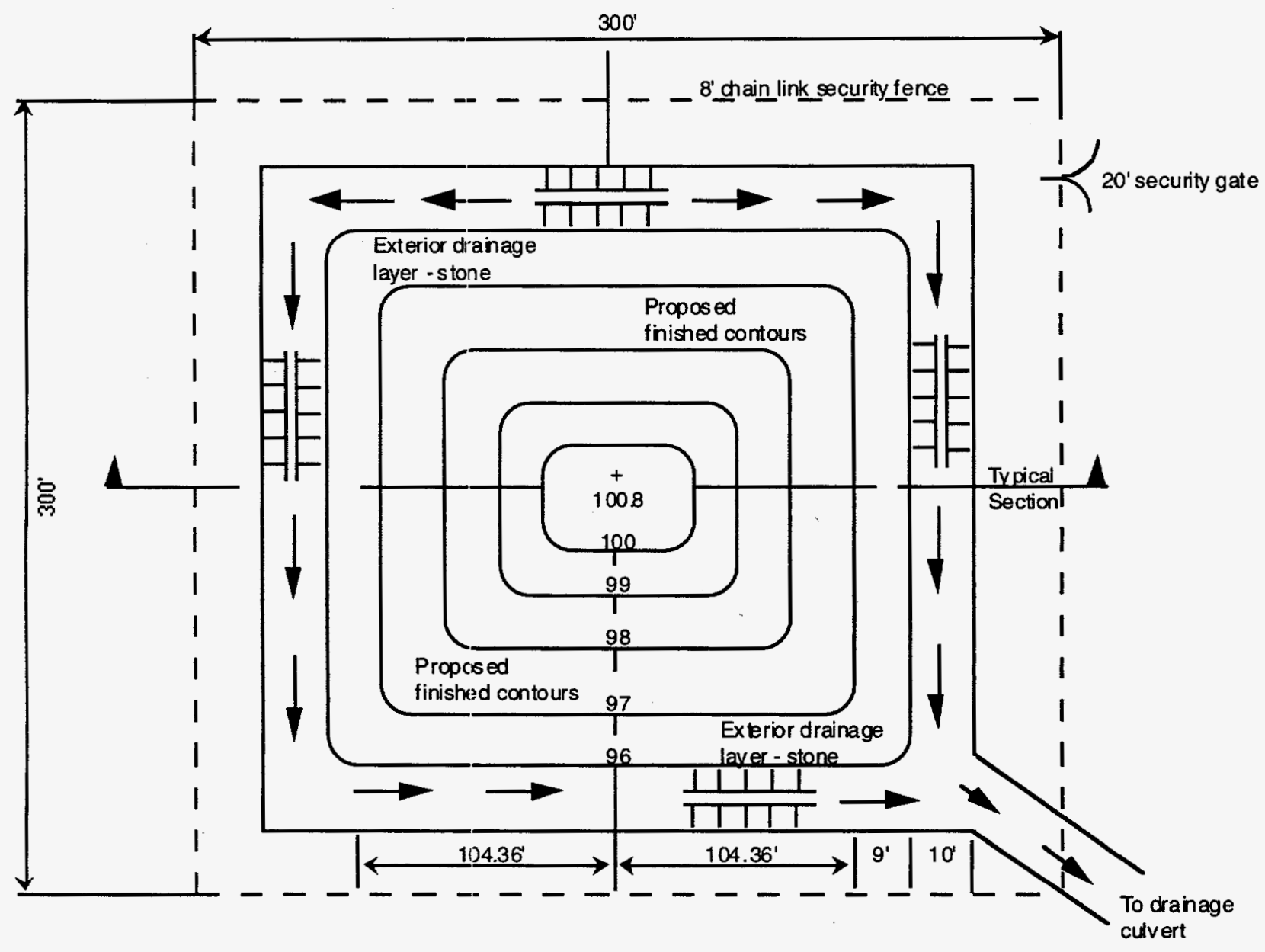

Not to Scale

Figure 3-1. Plan for a typical one-acre waste site cover system 


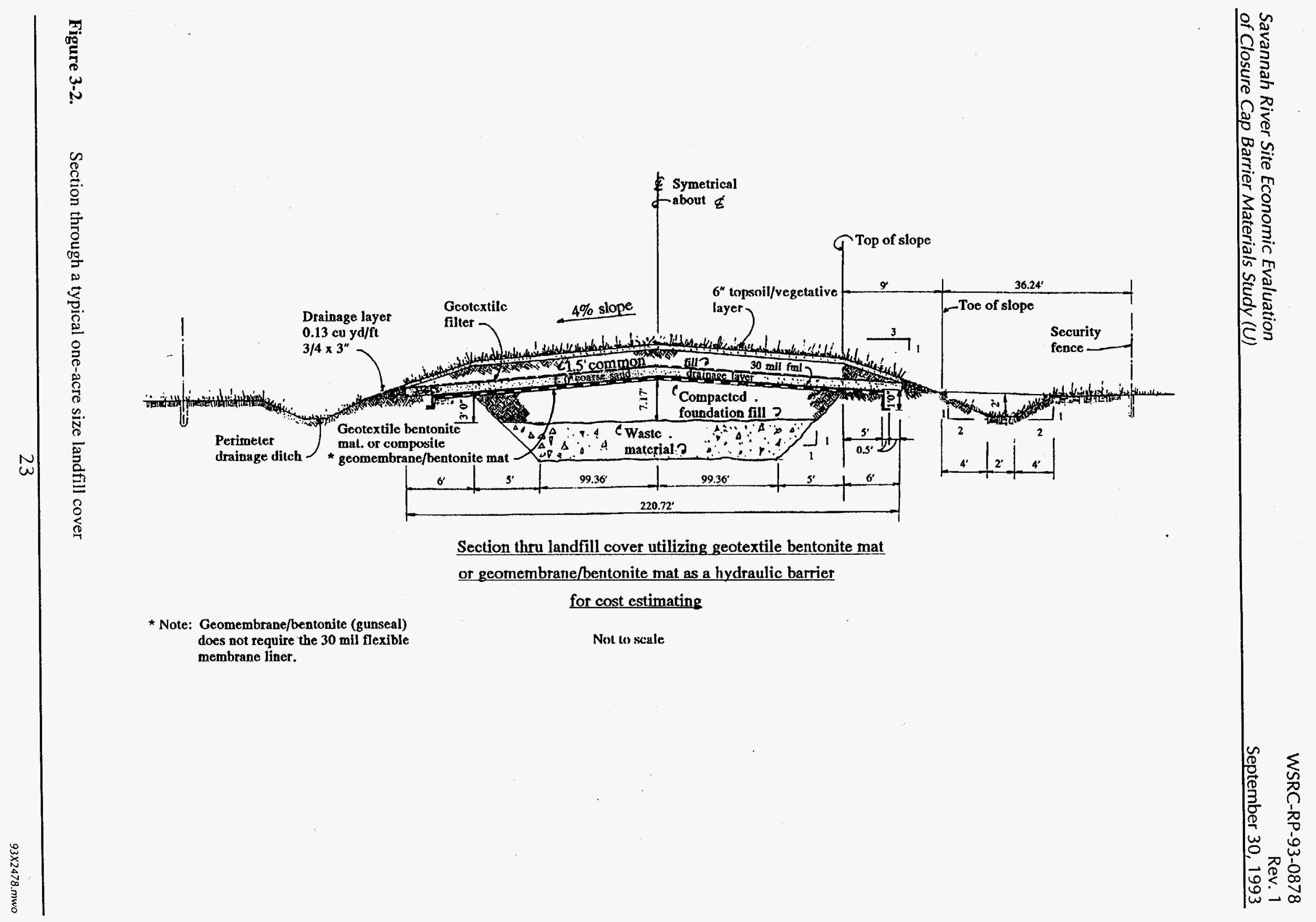




\subsection{Cost Estimating Methodology}

The methodology utilized for developing the cost estimates involves, in sequence, the following components:

1. selecting waste site size selection

2. developing construction activities and major cost items related to each type of cover system design

3. calculating cost

4. preparing cost estimates

\subsection{Waste Site Size Selection}

A review of SRS waste sites reveals that the sizes of these waste sites vary from a few hundred square feet to approximately 80 acres. Therefore, in developing the cost estimate, 10 different sizes were selected ( 0.1 acre, 0.2 acre, 0.5 acre, 1 acre, 2 acres, 5 acres, 10 acres, 20 acres, 40 acres, and 80 acres).

\subsection{Construction Activities and Major Cost Items}

As mentioned previously in Section 3.3, for the purpose of developing cost estimates, all the costs expected during closure, as well as postclosure periods, have been grouped into three major categories: site preparation costs, cover system construction costs, postclosure costs (O\&M costs).

Site preparation activities will be basically the same for all types of cover system designs. Generally, these will include site clearing and grubbing, precontouring the site, and constructing sediment controls, road(s), support facilities, and other related facilities and temporary structures.

Most of the construction activities will be common to all cover designs. Generally, these will include stabilizing waste material(s) exposed to the environment and preparing a foundation layer for the placement of the cover system, as well as drainage and vegetative layers including topsoil, as depicted in Figure 3-2. However, the activities involved in the actual placement/construction of the specific barrier material to form a low-permeability layer (e.g., geotextile bentonite mat or poured-in-place concrete slab) will depend upon the barrier material itself.

Additional activities associated with closing the site will generally include drilling and installing monitoring wells, erecting a security fence with gate and warning signs, decontaminating construction equipment, removing temporary site facilities, and demobilization.

Postclosure activities will be primarily related to the operation and maintenance of cover systems. These activities may occur either quarterly or annually. Quarterly activities may include groundwater sample collection, lab analysis, and field inspection of a cover system. Annual activities may include maintaining groundwater monitoring wells, fences, gates, access roads, and other facilities and repairs for subsidence failures.

Prior to preparing the cost estimates, major construction activities for each type of cover system considered in this study were identified. The activities are listed in Appendix A. 


\subsection{Cost Calculations}

Before preparing cost estimates for each cover system design, it was necessary to develop configurations of all the cover systems. A configuration provides a clear pictorial view to the cost estimator and helps generate accurate quantity takeoffs for materials used in constructing a cover system. Based on the characteristics of each barrier material, the configurations included in Appendix A were developed, and material quantity takeoffs for each site were computed.

Quantities were determined based on the assumptions discussed in Section 3.3 and various dimensions depicted in the cover system configuration. Unit costs were developed using the various cost data sources discussed in Section 3.1. In the absence of cost data, lump-sum costs, based on best engineering judgment, were assumed.

Man-hours involved in any specific construction activity or O\&M activity were also computed based on the information provided by the cost data sources used in developing this study anc/or by personal field experience.

Estimated costs were calculated by multiplying the unit costs by the estimated quantities and adding the labor costs. The labor costs were calculated by multiplying the estimated manhours involved to complete an activity by the labor hourly rate. Craft support was estimated.

Costs for general items such as engineering design fees, administrative and legal services, and contingencies were calculated by assuming that these costs are a percentage of either the total of direct costs or the total of direct and indirect costs, depending upon the type of the cost item. Percentages slightly decrease as site sizes increases above 10 acres.

Where applicable, costs (BEMCAP) were calculated at $\$ 6$ per hour of the total man-hours required for initial construction any specific construction activity.

\subsection{Cost Estimates}

The total estimated cost for each cover system includes initial construction, operating, and maintenance costs.

\section{Initial Construction Costs}

Initial construction costs are those expenditures required to initiate and construct a cover system over a waste site. These costs would include only those expenditures that are expected to be incurred during the planning, designing, and construction of a cover system.

Construction costs are divided into direct and indirect costs. Direct costs are those expenditures necessary for the actual installation of the cover system, and indirect costs include expenditures such as engineering, supervision, legal, and other necessary services that are not part of actual field or construction activities.

\section{Direct Costs}

The major direct construction costs considered for cost estimating include the following:

- land and site development

- cover construction

- construction of temporary structures and facilities

- rental equipment and services

- decontamination and demobilization 
Land and site development costs include site clearing and grubbing, developing access roads, developing soil erosion controls, incorporating access controls such as fences and gates, and preparing the site for construction equipment and facilities.

Construction costs include site modifications such as waste stabilization, preparation of the foundation layer, placement of barrier materials, or construction of the low-permeability layer and the drainage and topsoil layers, etc. Construction costs are typically available for individual activities and include itemized costs for equipment, labor, and material. Labor costs include all fringe benefits, worker's compensation, and contractor fees.

Installing a cover system will require constructing a temporary building or renting a construction trailer. Construction costs also include the cost for the temporary facilities (water and sanitary services).

Equipment costs are those expenditures required for the actual installation of the barrier materials. These costs are included in the material installation costs as quoted by the suppliers. Equipment costs for other construction activities were documented.

Costs for disposing of waste materials generated during the construction of the cover system are included in the decontamination and demobilization costs.

\section{Indirect Costs}

The major indirect costs considered for cost estimating include costs for design, engineering, and other contingency allowances.

Engineering expenses will include costs for:

- administration and supervision

- cover system design and development

- drafting, monitoring, and testing

- project and cost engineering

- other costs, including legal fees, fees for obtaining license/permits, and health and safety costs

Contingency allowances are added to the total direct costs to account for unforeseen circumstances that could result in additional costs. Contingencies may include adverse weather conditions, delay by material suppliers, and inadequate site characterization resulting in additional sampling and lab work.

\section{Operation and Maintenance Costs}

Operation and maintenance (O\&M) costs include those postconstruction/installation costs necessary to ensure regulatory compliance, as well as continued effectiveness of the cover system.

The major O\&M costs considered in developing the cost estimates include costs for groundwater monitoring, routine field inspection, and repairs for the monitoring wells, fences, gates, vegetative cover, and subsidence failures. 


\section{Total Estimated Costs}

To determine the total estimated cost, a standard procedure known as present worth analysis was adopted. Present worth analysis provides a method of evaluating and comparing all costs that occur over different time periods by discounting all future expenditures to the present year. Therefore, the present worth or value of any cover system represents the amount of money that, if invested in the initial year (base year) of the design period and disbursed as needed, would be sufficient to cover all the present and future costs associated with it. For the purpose of calculating total costs, the initial construction costs were considered to occur in year 0 , the base year (1994). The O\&M costs represent the expenditures to occur during each year of the planned life of the cover system.

To calculate the present worth, the following assumptions were made:

- The discount rate, including the inflation or escalation rate, will be $5 \%$.

- The design period (life of a cover system), will be 30 years.

The present value of O\&M costs occurring every year over 30 years was determined from the following equation:

$$
P W=\sum_{t=1}^{t=30} \frac{X_{t}}{(1+i)^{t}}
$$

where:

$$
\begin{array}{lll}
\mathrm{PW} & = & \text { present worth } \\
\mathrm{X}_{\mathrm{t}} & = & \text { expenditures for the O\&M costs in year } \mathrm{t} \\
\mathrm{i} & = & \text { discount rate (i.e., } 5 \%) \\
\mathrm{t} & = & \text { year in which O\&M expenditures occur }
\end{array}
$$

The sum of the present worth values of each year for 30 years represents the present worth of the total $O \& M$ costs. When these costs are added to the total capital cost, it provides the total estimated project cost. 


\subsection{Cost Estimation Examples}

This section presents an example of calculating the total estimated cost for a composite cover system utilizing Claymax ${ }^{\circledR}$ (a geosynthetic clay liner) and a 30-mil FML. This example is for illustration only and should not be assumed to be an actual cost of covering the site. The assumed size of the site is 1 acre. For details, refer to Figures 3-1 and 3-2. See typical cost estimate for a 1-acre site in Appendix B.

\subsection{Initial Construction Costs}

The initial construction costs were developed using cost data sources discussed in Section 3.1, and quantities were computed using dimensions shown in Figures 3-1 and 3-2.

\section{Direct Costs:}

\section{Site Preparation (for assumptions refer to Section 3.3)}

- clearing and grubbing: 3.8 acres (assumed), 40 hours/acre @ $\$ 20 /$ hour plus $\$ 912$ for equipment $=\$ 3,950$ (rounded off to nearest $\$ 10$ )

- precontouring the site: 2.8 acres (assumed), 32 hours/acre, 90 hours of labor @ $\$ 20 /$ hour plus equipment @ $\$ 538=\$ 2,330$

- Silt fence: 900 feet @ $\$ 0.50 / \mathrm{ft}$ plus 90 hours and labor @ $\$ 20 /$ hour $=\$ 2,250$

- temporary sediment control: Lump sum of $\$ 400$ plus equipment $\$ 60=\$ 460$

- $\quad$ twenty-feet wide gravel haul road 8" deep: 620 feet @ $\$ 8.50 / \mathrm{ft}$ plus 124 hours labor of @ $\$ 20$ hour plus equipment @ $\$ 744=\$ 8,490$

- two 15-inch RCP culverts: 64 feet @ \$12/ft plus 64 hours labor @ \$20/hour plus equipment @ $\$ 384=\$ 2,430$

- 35-feet x 35-feet gravel decontamination pad: 160 square yards @ \$3/sq. yard plus 16 hours of labor @ \$20/hour plus equipment @ \$96 = \$900

- 35-feet x 6-feet x 4-feet washwater decontamination ditch: 35 cubic yards @ \$10/cu. yard plus 700 hours of labor @ $\$ 20$ /hour plus equipment $\$ 4,200=\$ 18,550$

- construction trailer rent (6 months): assumed $\$ 600$ /month plus $\$ 120$ /month in utilities = $\$ 4,320$

\section{Cover System Construction}

- waste stabilization: 2,014 tons crushed limestone @ \$100/ton plus 201 hours of labor @ $\$ 20$ /hour plus equipment @ $\$ 1,208=\$ 206,640$

- compacted foundation fill: 8,070 cubic yards (assume no material cost for the onsite soil), 1,332 hours of labor @ $\$ 20$ /hour plus equipment @ $\$ 7,989=\$ 34,620$

- placement of Claymax $®$ mat: 61,600 sq. feet @ \$0.45/sq. foot plus 616 hours of labor @ $\$ 20 /$ hour $=\$ 40,040$

- placement of 30 mil FML: 61,600 sq. feet @ \$0.18/sq. foot plus 493 hours of labor @ $\$ 20 /$ hour $=\$ 20,940$

- placement of 1-foot course sand drainage layer: 2,124 cubic yards @ $\$ 10.50 / \mathrm{cu}$. yard plus 64 hours of labor @ $\$ 20$ hour plus equipment $\$ 382=\$ 23,960$

- placement of geotextile filter: 7,011 sq. yards @ \$0.18/sq. yard plus 42 hours of labor @ $\$ 20 /$ hour $=\$ 2,100$

- placement of 1' 6" of common fill: 2,424 cu. yard @ \$3.75/cubic yard plus 145 hours of labor @ \$20/hour plus equipment @ \$873=\$12,870 
- placement of topsoil: 909 cubic yards @ $\$ 9.50 /$ cu. yard plus 64 hours of labor @ $\$ 20 /$ hour plus $\$ 382$ of equipment $=\$ 10,290$

- placement of exterior drainage layer: 297 sq. yards @ $\$ 1.50 /$ sq. yard plus 65 hours of labor @ \$20/hour plus equipment @ \$392=\$2,140

- drainage ditch: 441 cubic yards, 82 hours of labor @ $\$ 20$ /hour plus $\$ 490$ worth of equipment $=\$ 2,120$

- seeding, fertilizing, and mulching: 10,000 sq. yards @ $0.25 /$ sq. yard plus 160 hours of labor @ $\$ 20$ hours plus equipment @ $\$ 960=\$ 6,660$

- installation of security fence: 1,180 feet @ $\$ 12 / \mathrm{ft}$ plus 295 hours of labor @ $\$ 20 /$ hour plus equipment @ $\$ 1,770=\$ 21,830$

- installation of security gate: one gate @ \$1,500 plus 24 hours of labor @ $\$ 20 /$ hour $=$ $\$ 1,980$

- warning signs: four @ $\$ 250$ each plus eight hours of labor @ $\$ 20 /$ hour $=\$ 1,160$

- survey final cover and subsidence markers: (assumed) $\$ 1,200$

- Groundwater monitoring wells: four @ \$500 each plus 320 hours of labor @ \$20/hour plus $\$ 1,920$ worth of equipment $=\$ 10,320$ SUBTOTAL: $\$ 442,550$

- Escalation for 1994 on direct labor @ 1.9\% and on material @ 2.5\%=\$9,720

- Cleanup and demobilization: (assumed) 5\% of the total direct costs $=5 \% \times \$ 452,270=$ $\$ 22,6,10$

- Locarion factor: (assumed) $40 \%$ of total labor cost plus escalation $=40 \% \times \$ 104,880=$ $\$ 41,950$

TOTAL I)IRECT COSTS $=\$ 516,830($ rounded off to the nearest $\$ 10)$

\section{Indirect Costs}

- certification of the final cover: (assumed) $3 \%$ of the total direct cost $=3 \% \times \$ 516,830=$ $\$ 15,500$ (rounded off to the nearest $\$ 10$ )

- health and safety: (assumed) $5 \%$ of the total direct cost $=5 \% \times \$ 516,830=\$ 25,840$

- scope contingencies: (assumed) $10 \%$ of the total direct cost $=10 \% \times \$ 516,830=\$ 51,680$

- administrative and legal: (assumed) $10 \%$ of the total direct cost $=10 \% \times \$ 516,830=$ $\$ 51,680$

- engineering and services: (assumed) $20 \%$ of the total direct cost $=20 \% \times \$ 516,830=$ $\$ 103,370$

- construction support: @ $20.8 \%$ of total man-hour @ $19 / \mathrm{hr}=20.8 \% \times 5150 \mathrm{hr} \times 19=$ $\$ 20,350$

- field indirect on total direct labor @ 46.5\% and material @ 26.5\%: $\$ 152,590$

- constuction nonmanual @ 25.2\% of total direct man-hours @ $\$ 43.68$ hour: $\$ 56,690$

- Project management @ $8 \%$ of total direct \& indirects: $\$ 79,560$

TOTAL INDIRECT COSTS $=\$ 557,260$

The total estimated initial construction costs is the sum of direct costs and indirect costs. Therefore, total construction cost for the cover system is $\$ 1,074,000$ (rounded off to nearest thousand dollars).

\subsection{Operation and Maintenance (O\&M) Costs}

Annual O\&M costs were estimated for groundwater monitoring and other quarterly and annual activities.

- groundwater monitoring laboratory: 16 samples @ $\$ 225$ each $=\$ 3,600$

- cover inspection activities (assumed monthly): 4 hours x $12=48$ hours @ $\$ 75 /$ hour = $\$ 3,600$ 
- subsidence monitoring (assumed once a year): 16 hours @ $\$ 75 /$ hour $=\$ 1,200$

- maintenance of vegetative cover: (assumed) $\$ 1,000$

- cover repair due to subsidence: $\$ 800$ (assumed 5 sinkholes over a 30-year period)

- maintenance of fence, gate, and signs: (assumed) $\$ 300$

- monitoring of wells: 4 wells @ $\$ 75 /$ well $=\$ 300$

The total $O \& M$ costs are $\$ 10,800$ annually.

\subsection{Total Cost (Total Present Worth)}

Assuming a discount rate of $5 \%$, the present worth of O\&M costs over a period of 30 years results in a sum of $\$ 10,800 \times 15.3725=\$ 166,000$ (rounded off to nearest thousand dollars). Construction costs are assumed to be incurred during year 0 (1994) of the 30-year period. O\&M costs are assumed to be incurred for years 1 through 30 . The total present worth is the sum of total construction costs and total present worth of O\&M costs. Therefore, the total project cost is $\$ 1,074,000+\$ 166,000=\$ 1,240,000$ (rounded off to the nearest thousand). 


\subsection{Cost-Effectiveness Analysis}

\subsection{Cost Curves}

This revised study has sought to establish the most cost-effective cover barrier material for a given SRS waste site. To accomplish the objective, 10 sizes $(0.1,0.2,0.5,1,2,5,10,20,40$, and 80 acres) were utilized.

In the previous study (Rev. 0$)$, six sizes $(0.1,0.2,0.5,1,2$, and 5 acres) were selected because they constitute the majority ( $75 \%-80 \%)$ of sites to be closed. However, after completing the study, it became evident that four more site sizes (10,20,40, and 80 acres) were needed to cover the full range of SRS sites. Twelve barrier materials identified and characterized in the previous study (Rev. 0) were used for evaluation. By employing the cost-estimating methodology and cost-estimating procedures discussed in Sections 4.0 and 5.0, 120 estimates were generated. The cost estimates are summarized in Table 6-1.

Utilizing the results from these cost estimates, graphs and tables for each site size were prepared. The graphs were structured to depict cost per square foot versus the barrier materials for each site size. These graphs offer a quick comparison between the costs of the barrier materials from the least to the most expensive and are shown in Figures 6-1 through 6-10. Tables 6-2 through 6-11 provide the exact cost per square foot and also rank the materials from 1 to 12 with 1 being the most cost-effective.

To better understand the significance of barrier materials and project duration, a graph depicting relative man-hours versus barrier materials was also prepared and is shown in Figure 6-11. This figure shows a breakpoint at about the 10-acre size. This means below 10 acres, the project duration (in terms of man-hour requirements over a certain period of time) do not significantly impact the cost-effectiveness of any barrier material considered for evaluation in this study. However, for sites larger than 10 acres, both material cost and project duration play a significant role in the overall cost-effectiveness of a barrier material.

For each material, a composite cost curve showing the relationship between the site size and cost per square foot of covering the site with the material is also plotted. The cost curves for all the 12 materials are shown in Figures 6-12 through 6-15. To provide a clear overall view, two sets of composite cost curves were prepared. One set of composite curves (Figures 6-12 and 6-14) range from 0.1 acres to 5 acres and the other set (Figure 6-13 and 6-15) ranged from 5 acres to 80 acres.

For further clarity, the composite cost curves were grouped into two sets, each incorporating six of the selected barrier materials. Single layer materials, such as the geosynthetics and single-layer sprayed asphalts, were incorporated onto one set of graphs (Figures 6-12 and 614), while barrier materials requiring compaction or consisting of hard surface covers were included in another set of graphs shown in Figures 6-13 and 6-15. From these curves, costs per square foot can be interpolated for any site size other than those utilized in this study.

In the following section, the composite per-square-foot costs of all the barrier materials are compared. 


\subsection{Cost Comparisons}

The composite per-square-foot cost includes the cover system's construction cost and the O\&M cost amortized over a design period of 30 years, the minimum tegulatory postmaintenance requirement period. From Figures 6-12 through 6-15, it is apparent that as the site size increases from 0.1 acre to 1 acre, the per-square-foot cost for all the barrier materials decreases dramatically. The per-square-foot cost decreases by approximately $70 \%$. This is evident by observing the steepness of the curve slopes between the 0.1-and 1-acre site sizes. As the size increases from 1 acre to 5 acres, the cost curves start flattening out, representing only small changes in the per-square-foot cost. On the average, the cost increases by approximately $\$ 3$ per square foot per acre as the site size increases from 1 acre to 5 acres. This is primarily because of the economy of scale. Between 5 acres and 80 acres, the cost curves almost flatten out, presenting very small changes in per-square-foot costs. On the average, the cost increases by approximately $\$ .10$ per square foot per acre as the site size increases from 5 acres to 80 acres.

\subsubsection{Site Size 0.1 Acre to 10 Acres}

For site sizes 0.1 acre to 10 acres, 120 -mil FML, Gundseal $\circledast$, and onsite compacted clay provide the most cost-effective barrier materials and rank either first, second, or third, respectively. The approximate per-square-foot costs for these materials range from $\$ 92$ (for 0.1 acre) to $\$ 14$ (for 10 acres). For a given site size between 0.1 acre and 10 acres, the cost variance is very little between these three barrier materials (refer to Figures 6-12 and 6-14) and, therefore, any one of these can be considered cost-effective. Neither the 120-mil FML or Gundseal@ require a 30-mil FML as part of the barrier material, and this may explain why these two materials are cost-effective. The onsite clay has the inherent advantage of being a natural resource of SRS and, therefore, has no material costs associated with it.

The next most cost-effective set of barrier materials include Claymax $\circledast$, Bentomat $\circledast, 1 / 4$-inchthick hot sprayed asphalt, bentonite soil additive, and 1/4-inch-thick reinforced sprayed asphalt. The approximate per-square-foot costs range from $\$ 93$ (for 0.1 acre) to $\$ 15$ (for 10 acres).

Basically, there are two reasons why these barrier materials are more expensive than the first set of barrier materials. All of these barrier materials require a 30-mil FML as part of the composite barrier system. Because of the 30-mil FML, the sinkhole repair costs are higher because the liner has to be replaced. Higher sinkhole repair costs result in significantly higher operation and maintenance costs.

The third and final set of barrier materials comprised the offsite compacted clay, soil cement, the asphalt concrete slab, and the concrete slab. These materials average approximately $\$ 4.20$ more per square foot than the most cost-effective barrier materials. Between these four materials, the offsite compacted clay is the most cost-effective material for sites up to and including one acre. After one acre, the asphalt concrete slab becomes the best alternative. These materials also require a 30-mil FML layer and result in higher sinkhole repair and replacement costs. In addition, these barrier systems have higher material and equipment costs and are more labor intensive.

It would be prudent to assume that a single-layer geotextile bentonite mat (such as Claymax $($ ), FML, or a geomembrane would take less manpower and consequently less project duration to construct. However, the man-hour analysis and the graph shown in Figure 6-11 indicate that for site sizes smaller than 10 acres, project duration, with other construction items being equal, has no significant affect on the project cost. In other words, for smaller 


\begin{tabular}{|c|c|c|c|c|c|c|c|c|c|c|c|c|c|c|c|c|c|c|c|c|c|c|c|c|c|c|c|c|c|c|c|}
\hline & & \multicolumn{30}{|c|}{ Stre size } \\
\hline \multirow{3}{*}{ * } & \multirow{3}{*}{ Cover System } & \multirow{2}{*}{\multicolumn{3}{|c|}{\begin{tabular}{c|}
0.1 Acre \\
Estimated Total Costs \\
(SK)
\end{tabular}}} & \multirow{2}{*}{\multicolumn{3}{|c|}{$\begin{array}{l}0.2 \mathrm{Act} \\
\text { Extimated Total Cost } \\
\text { (SK) }\end{array}$}} & \multirow{2}{*}{\multicolumn{3}{|c|}{$\begin{array}{l}0.5 \text { Acre } \\
\text { Estimated Total Costs } \\
\text { (SK) }\end{array}$}} & \multicolumn{3}{|c|}{1 Acre } & \multicolumn{3}{|c|}{2 Actes } & \multicolumn{3}{|c|}{ SAcres } & \multicolumn{3}{|c|}{ 10 Anes } & \multicolumn{3}{|c|}{20 Acres } & \multicolumn{3}{|c|}{40 Acres } & \multicolumn{3}{|c|}{ 80 Acres } \\
\hline & & & & & & & & & & & Estima & $\begin{array}{l}\text { ated Total } \\
\text { (sk) }\end{array}$ & Costs & Estims & $\begin{array}{l}\text { ted Total } \\
\text { (sto }\end{array}$ & Costs & Estimat & $\begin{array}{l}\text { ated Total } \\
\text { (SK) }\end{array}$ & 2 Costs & Estima & $\begin{array}{l}\text { ated Total } \\
\text { (\$k) }\end{array}$ & 11 Costs & Estima & $\begin{array}{l}\text { ted Total } \\
\text { (S1) }\end{array}$ & $1 \cos t s$ & Estima & $\begin{array}{l}\text { ated Total } \\
\text { (SK) }\end{array}$ & Costs & & $\begin{array}{l}\text { 1ated Total } \\
(\leqslant x)\end{array}$ & Costs \\
\hline & & Capital & o\&M & $\begin{array}{l}\text { Present } \\
\text { Wort }\end{array}$ & Captal & OEM & 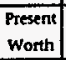 & Coptat & Oбсм & $\begin{array}{l}\text { Present } \\
\text { Worth }\end{array}$ & Cappltal & Or:M & $\begin{array}{l}\text { Present } \\
\text { Worth }\end{array}$ & Captuat & Oosm & $\begin{array}{l}\text { Present } \\
\text { Woreh } \\
\end{array}$ & Capital & Ossm & $\begin{array}{l}\text { Present } \\
\text { Worth } \\
\end{array}$ & Capital & ogsm & \begin{tabular}{|l|} 
Present \\
Worth
\end{tabular} & Capteal & Os:M & \begin{tabular}{|l|} 
Present \\
Worth
\end{tabular} & Captzal & ossm & $\begin{array}{c}\text { Present } \\
\text { Worth }\end{array}$ & Capteal & osint & \begin{tabular}{|c|} 
Present \\
Worth
\end{tabular} \\
\hline 1: & $\begin{array}{l}\text { Cover System Uallating Caymoux } \\
\text { and a } 30 \text { mil F FML }\end{array}$ & 260 & 147 & 407 & 358 & 149 & s07 & 636 & 154 & 790 & 1,074 & 166 & 1,240 & 1,931 & 198 & 2,129 & 4,494 & 264 & 4,758 & 6.120 & 345 & 6,465 & 11,481 & 523 & 12,008 & 18,249 & 1,036 & 19,285 & 34,410 & 1,617 & 36,027 \\
\hline 2. & $\begin{array}{l}\text { Cover System Udiluting Bentomuto } \\
\text { and a 30-mil PML }\end{array}$ & 260 & 147 & 407 & 358 & 149 & 507 & 636 & 154 & 290 & 1,074 & 166 & 0,240 & 1,931 & 198 & 2,129 & 4,494 & 264 & 4,758 & 6.120 & 345 & 6.465 & 11,481 & 527 & 12,008 & 18,250 & 1,036 & 19,286 & \begin{tabular}{|l|}
34,410 \\
\end{tabular} & 2,617 & 36,027 \\
\hline 3. & Cover System Utillang Gundseals & 253 & 146 & 399 & 345 & 148 & 493 & 605 & 154 & 759 & 1,020 & 165 & 1,185 & 1,829 & 196 & 2.025 & 4,240 & 261 & 4,501 & 5,712 & 339 & 6,052 & 11,023 & 519 & 11,542 & 16,832 & 1,025 & 17,857 & 31,800 & 1,605 & 33,405 \\
\hline 4. & 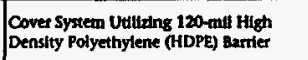 & 253 & 146 & 399 & 345 & 148 & 493 & 605 & 154 & 759 & 1,020 & 165 & 1,185 & 1,829 & 196 & 2,025 & 4,240 & 261 & 4,501 & 5,788 & 339 & 6,127 & 10,841 & $s 19$ & 11,360 & 16,975 & 1,025 & 18,000 & 31,869 & 1,605 & \begin{tabular}{|l|}
33,474 \\
\end{tabular} \\
\hline s. & 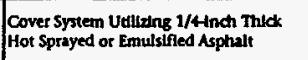 & 257 & 147 & 404 & 354 & 149 & 503 & 623 & 154 & 777 & 1,055 & 166 & 1,221 & 1,893 & 298 & 2,091 & 4,398 & 264 & 4,662 & 6,304 & 345 & 6,649 & 11,980 & 527 & 12,507 & 19,135 & 1,036 & $20,17 n$ & 36,588 & 1,617 & 38,205 \\
\hline 6. & $\begin{array}{l}\text { Cover Syyeem Uallizing Retiforceed } \\
\text { Sprayed Asphalt }\end{array}$ & 258 & 147 & 405 & 354 & 150 & 504 & 626 & 155 & 781 & 1,062 & 167 & 1,229 & 1,926 & 199 & 2,125 & 4,436 & 26) & 4,703 & 6,353 & 349 & 6,702 & 12,076 & $\mathbf{s 3 3}$ & 12,609 & 19,310 & 1.043 & 20,353 & 36,949 & 1,628 & 38,577 \\
\hline 7. & 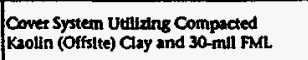 & 260 & 152 & 412 & 360 & 156 & 516 & 640 & 165 & 805 & 1,090 & 181 & 1,271 & \begin{tabular}{|l|}
1,967 \\
\end{tabular} & 227 & 2,194 & 5,011 & 322 & \begin{tabular}{|l|l|}
5,333 \\
\end{tabular} & 6,846 & 434 & 7,280 & 13,504 & 6055 & \begin{tabular}{|l|}
14,159 \\
\end{tabular} & 21,343 & 1,205 & \begin{tabular}{|l|}
22,548 \\
\end{tabular} & \begin{tabular}{|l|l|}
40,508 \\
\end{tabular} & 1,817 & 42,325 \\
\hline 8. & $\begin{array}{l}\text { Cover Sytem Utillzing Compaced } \\
\text { Onste Clay and } 30 \text {-mlt FML. }\end{array}$ & 252 & 151 & 403. & 342 & iss & 497 & 596 & 164 & 760 & 1,008 & 181 & 1,189 & 1,787 & 224 & 2,011 & 4,135 & 318 & 4,453 & 6,023 & 429 & 6,452 & 11,814 & 649 & 12,463 & 18,148 & 1,196 & 19,344 & $34,307 \mid$ & 1,807 & 36,114 \\
\hline 9. & $\begin{array}{l}\text { Cover System Udillzing Soll Cement } \\
\text { and } 30 \text { - mill FML }\end{array}$ & 277 & 152 & 429 & 389 & 156 & 545 & 722 & 164 & 886 & 1,253 & 181 & 1,434 & 2,290 & 226 & 2,516 & 5,391 & 321 & 5,712 & 7,944 & 134 & 8,378 & 15,913 & 655 & 16,568 & 26,252 & 1,205 & 27,457 & $48,786 \mid$ & 1,816 & $|50,602|$ \\
\hline 10. & $\begin{array}{l}\text { Cover System Utituang Bentonite } \\
\text { Soll Adóitlve and 30-mil FML }\end{array}$ & 256 & 148 & 104 & 350 & 151 & 501 & 624 & 158 & 782 & 1,057 & 172 & 1,229 & 1,871 & 208 & 2,079 & 4,374 & 286 & 4,660 & 6,291 & 379 & 6,670 & 11,905 & 575 & 12,480 & $|18,989|$ & $\mid 1,099$ & 20,088 & 36,243 & \begin{tabular}{|l|l|} 
& 1.693 \\
\end{tabular} & 37,936 \\
\hline 11. & 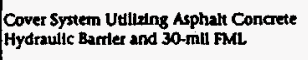 & 264 & 153 & 417 & 362 & 158 & 520 & 639 & 171 & 810 & 1,201 & 193 & 2,394 & 1,936 & $23 \overline{4}$ & 2,170 & 4,481 & 283 & 4,764 & 6,346 & 420 & 6,766 & 12,300 & 661 & 12,961 & 20,170 & 1,275 & 21,445 & 37,711 & \begin{tabular}{|l|}
2,053 \\
\end{tabular} & 39,764 \\
\hline 12. & $\begin{array}{l}\text { Cover System Utuluring Pourred-A-Flace } \\
\text { Concrete Slab and } 30 \text {-mul FML. }\end{array}$ & 282 & 155 & 437 & 399 & 161 & 560 & 730 & 173 & 903 & 1,233 & 193 & 1,126 & 2,229 & 245 & 2,474 & 5,213 & 344 & 5,557 & 7,395 & 502 & 7,897 & 14,341 & 779 & 15,120 & 24,288 & $\mid 1,431$ & 25,719 & 45,864 & 2,235 & 48,099 \\
\hline
\end{tabular}

$\begin{array}{lll}m+1 & m \\ r i d & m i\end{array}$


sites, project duration has no significant impact on the economic analysis and selection of a barrier material for a specific site.

\subsubsection{Site Size 10 Acres to 80 Acres}

For site sizes between 10 acres and 80 acres, Gundseal ${ }^{\circledR}$ and FML prove to be the most costeffective barrier materials. However, as the site size increases from 10 acres to 20 acres and beyond, Bentomat ${ }^{\circledR}$ and Claymax ${ }^{\circledR}$ also become cost-effective. For sites larger than 20 acres, both Bentomat ${ }^{\circledR}$ and Claymax $\otimes$ become more cost-effective than onsite compacted clay and clearly rank third and fourth as the most cost-effective barrier materials, respectively.

A close examination of per-square-foot costs for Gundseal ${ }^{\circledR}$ and 120-mil FML reveals that the cost variance between these two materials favors the Gundseal ${ }^{\circledR}$ up to a 20 -acre-site. For sites larger than 20 acres, the cost variance is insignificant and either material could be utilized as the barrier material. As previously discussed in Section 6.2.1, the Gundseal@ and 120-mil FML do not require a 30-mil FML and, therefore, result into lower sinkhole repair costs and eventually lower per-square-foot costs.

Next to Gundseal ${ }^{\circledR}$ and 120 -mil FML Claymax ${ }^{\circledR}$, Bentomat ${ }^{\circledR}$ and onsite compacted clay offer the most cost-effective barrier materials and cost, on the average, approximately $\$ 0.80$ per square foot more. For sites less than 10 acres, both Claymax ${ }^{\circledR}$ and Bentomat ${ }^{\circledR}$ did not result in cost-effective barrier materials. The primary reason being the lack of project duration for smaller sites. However, for sites greater than 10 acres, the project duration factor becomes of great influence. The analysis of man-hours involved in constructing the barrier material as shown in Figure 6-11, reveals that the project duration factor can range between a value of 2 and 22 for sites 10 acres to 80 acres. Because the single-layer geotextile bentonite mats (Claymax $\otimes$, Bentomat ${ }^{\circledR}$, Gundseal $\left.{ }^{\circledR}\right)$ can be placed easily and rapidly, the project duration is much less for geosynthetic bentonite mats, resulting in more cost-effectiveness. The closure costs decrease significantly with decreasing project duration. The onsite compacted clay is also cost-effective compared to Claymax $(B)$ and Bentomat ${ }^{\circledR}$ because no material cost is involved.

The third most cost-effective barrier materials group consists of sprayed asphalt layers and the bentonite soil additive. However, these barrier materials average $\$ 1.30$ per-square-foot more than the most cost-effective barriers. For closure sites 10 acres and larger, this increase in persquare-foot cost could cause a substantial increase in the closure cost. Again, this cost increase for these barrier materials is attributed to the cost of using a 30-mil FML as a component of the barrier system.

The final group of cost-effective barrier materials, which cost anywhere from $\$ 2.00$ to $\$ 5.00$ per square foot more than the most cost-effective barrier materials, include a 4-inch asphalt concrete slab, offsite compacted clay, a 4-inch concrete slab, and a 3-foot compacted soil cement cover. These materials are the least cost-effective for the same reasons cited above for the asphalt barrier materials, and they have higher project duration factors and higher material and equipment costs. Of the four materials, the 4-inch asphalt concrete slab is the least expensive and averages $\$ 1.90$ per-square-foot more than the most cost-effective barrier materials. The offsite clay barrier averages $\$ 2.75$ more, while the 4-inch concrete slab is $\$ 4.25$ per square foot greater than the most cost-effective materials. The most expensive barrier material proved to be the 3-foot compacted soil cement with an average cost of $\$ 5.40$ persquare-foot greater than the most cost-effective materials. 


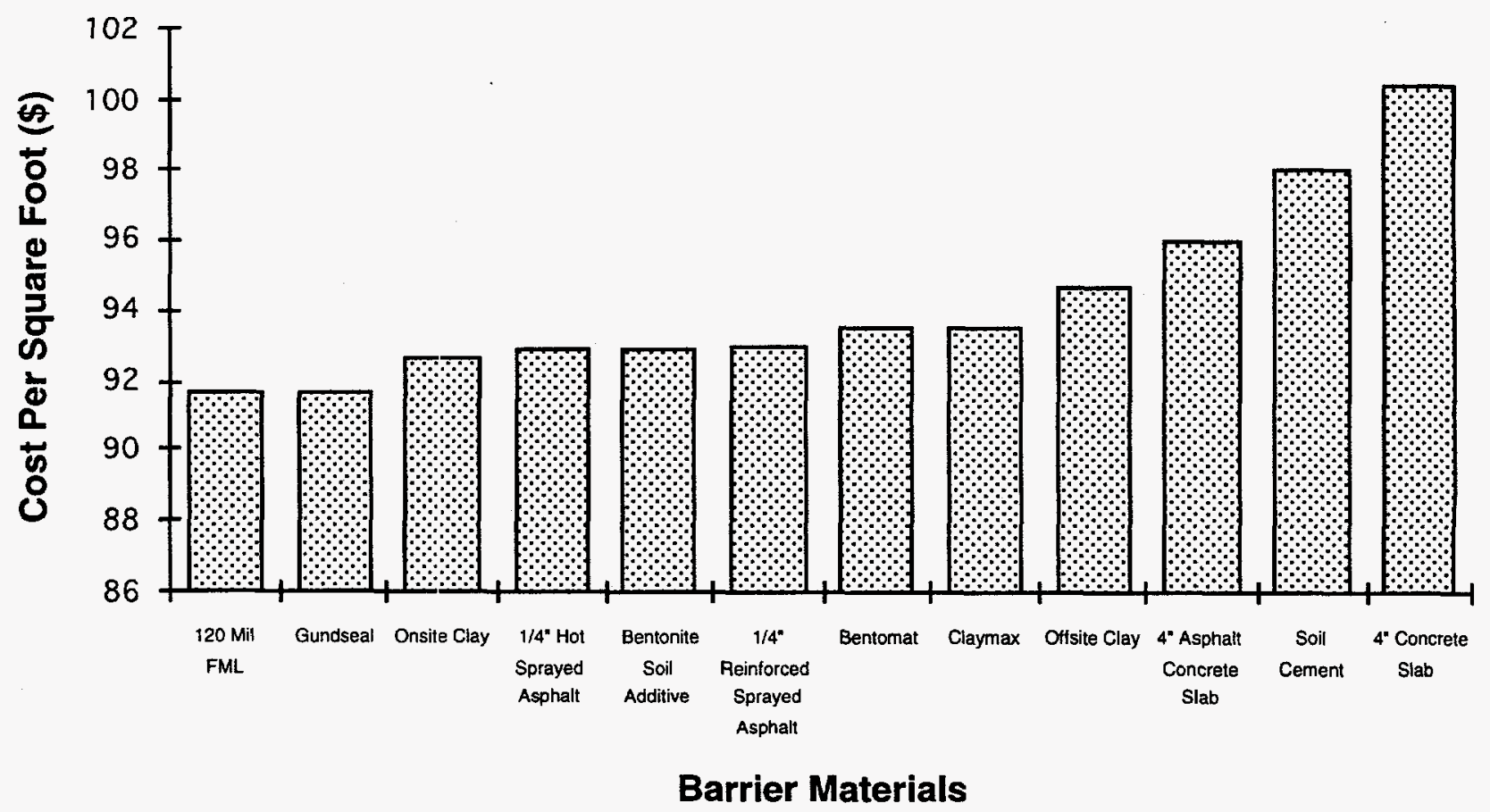

Figure 6-1. Column charts showing barrier material costs for 0.1 acre site 


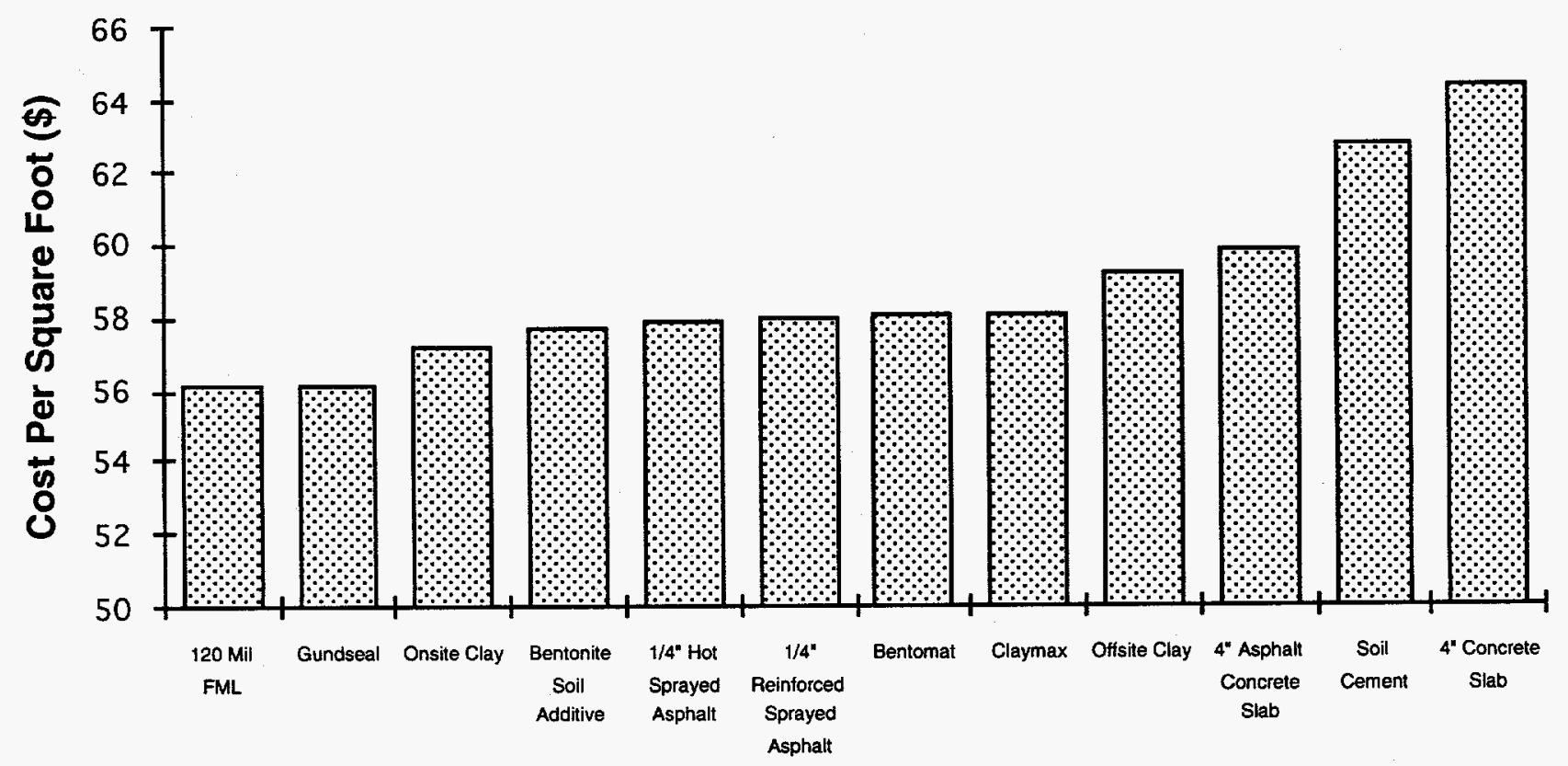

Barrier Materials

Figure 6-2. Column charts showing barrier material costs for 0.2 acre site 


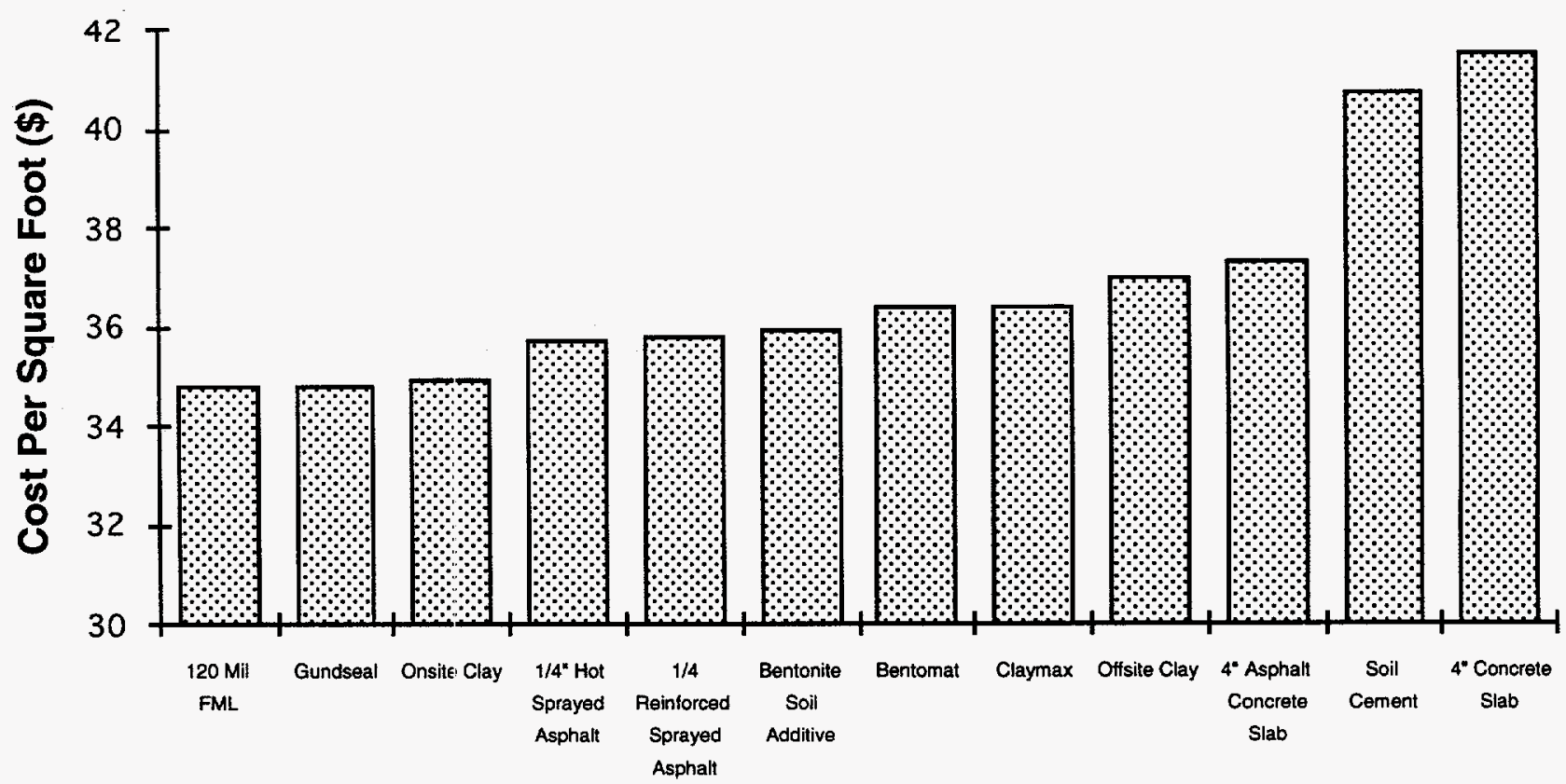

Barrier Materials

Figure 6-3. Column charts showing barrier material costs for 0.5 acre site 


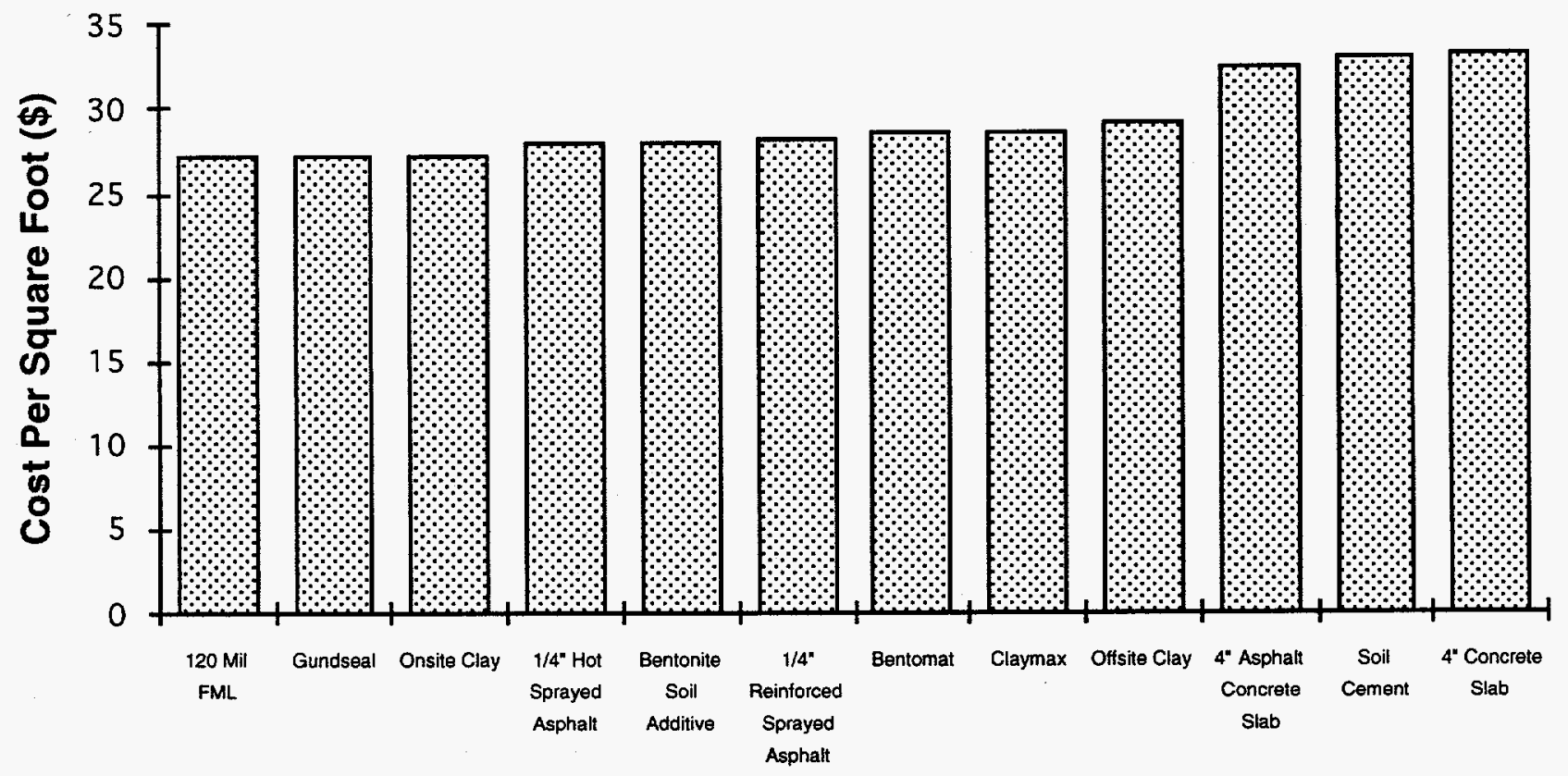

Barrier Materials

Figure 6-4. Column charts showing barrier material costs for 1-acre site 


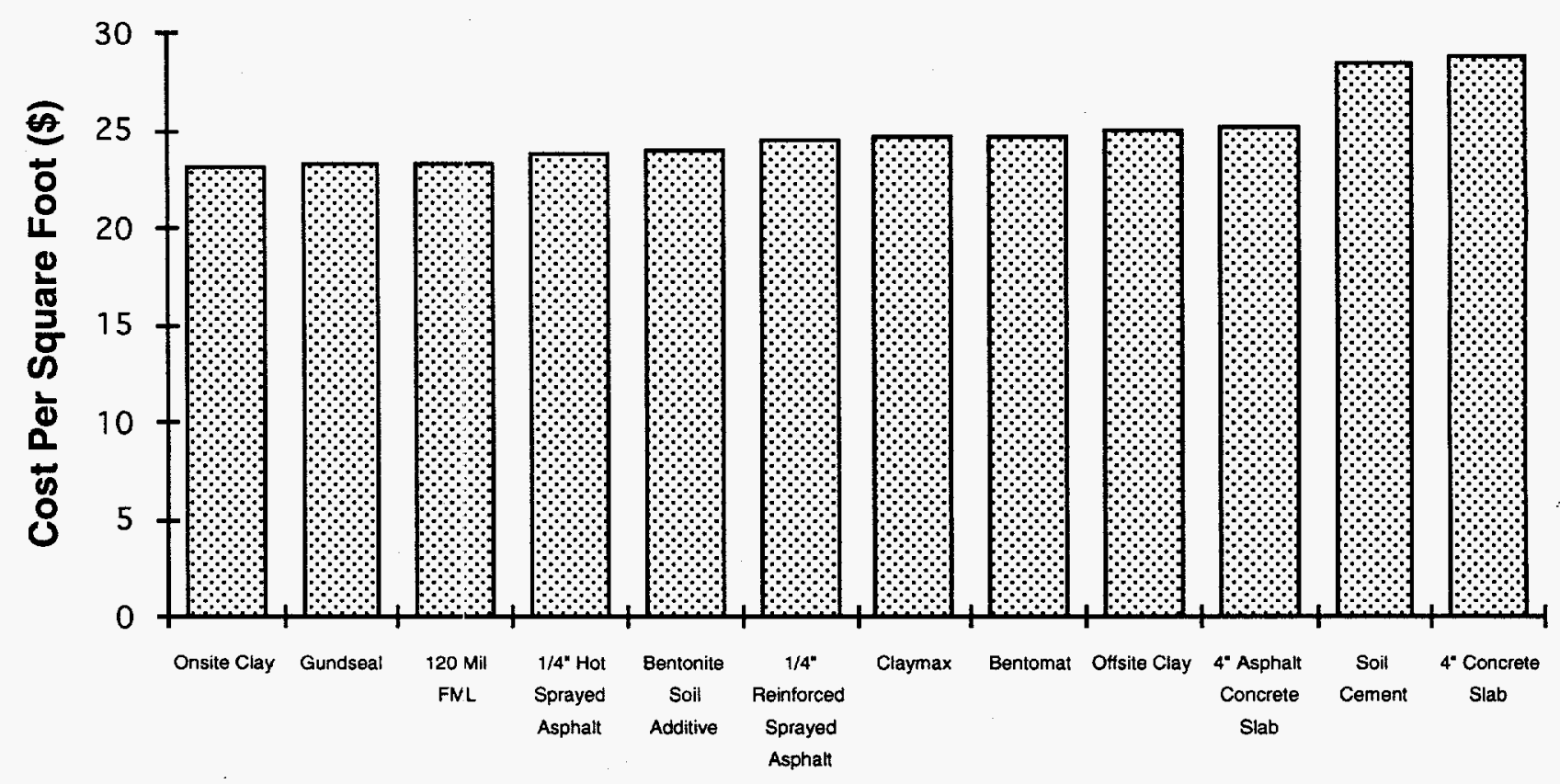

\section{Barrier Materials}

Figure 6-5. Column charts showing barrier material costs for 2-acre site 


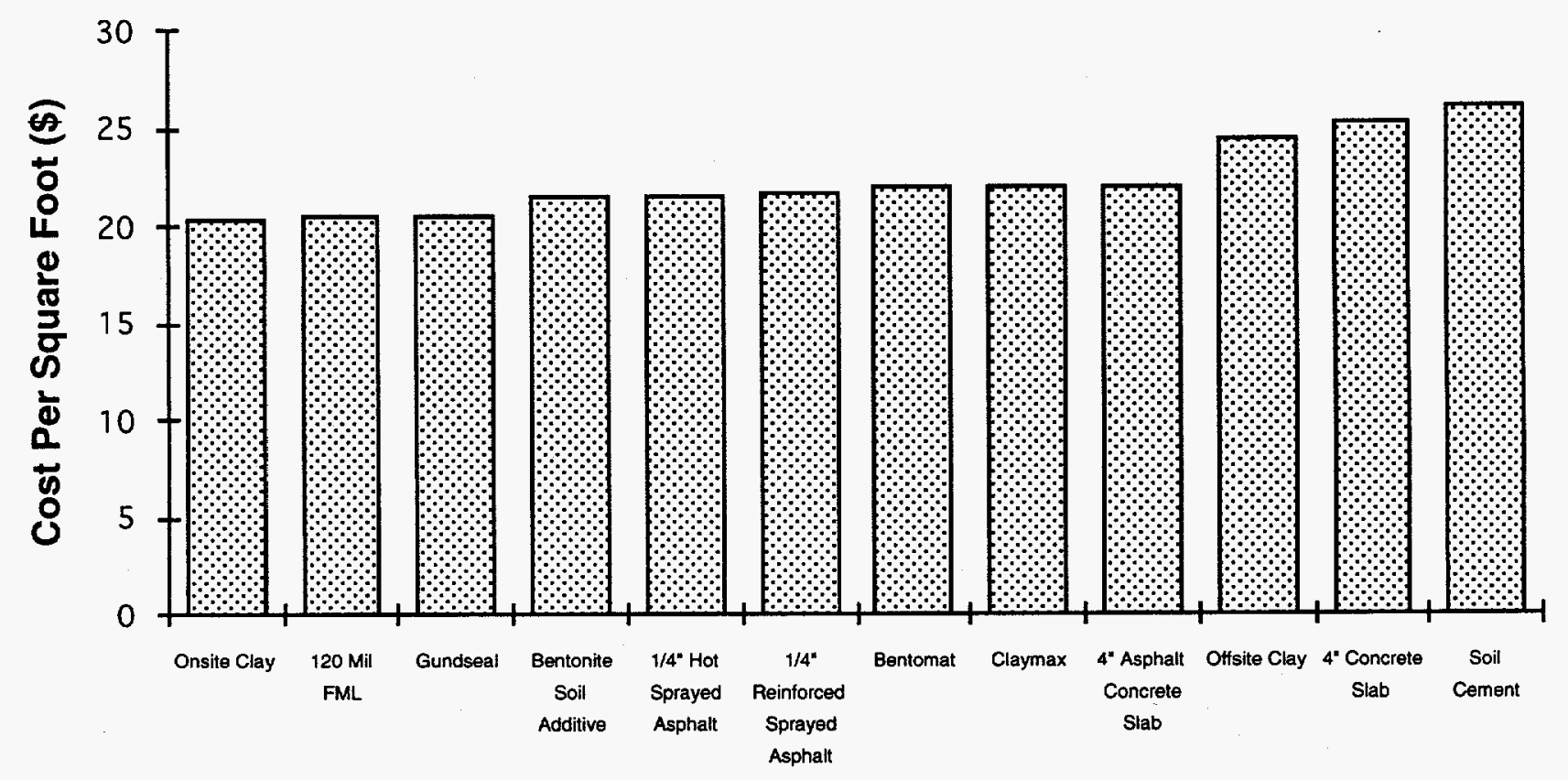

\section{Barrier Materials}

Figure 6-6. Column charts showing barrier material costs for 5-acre site 


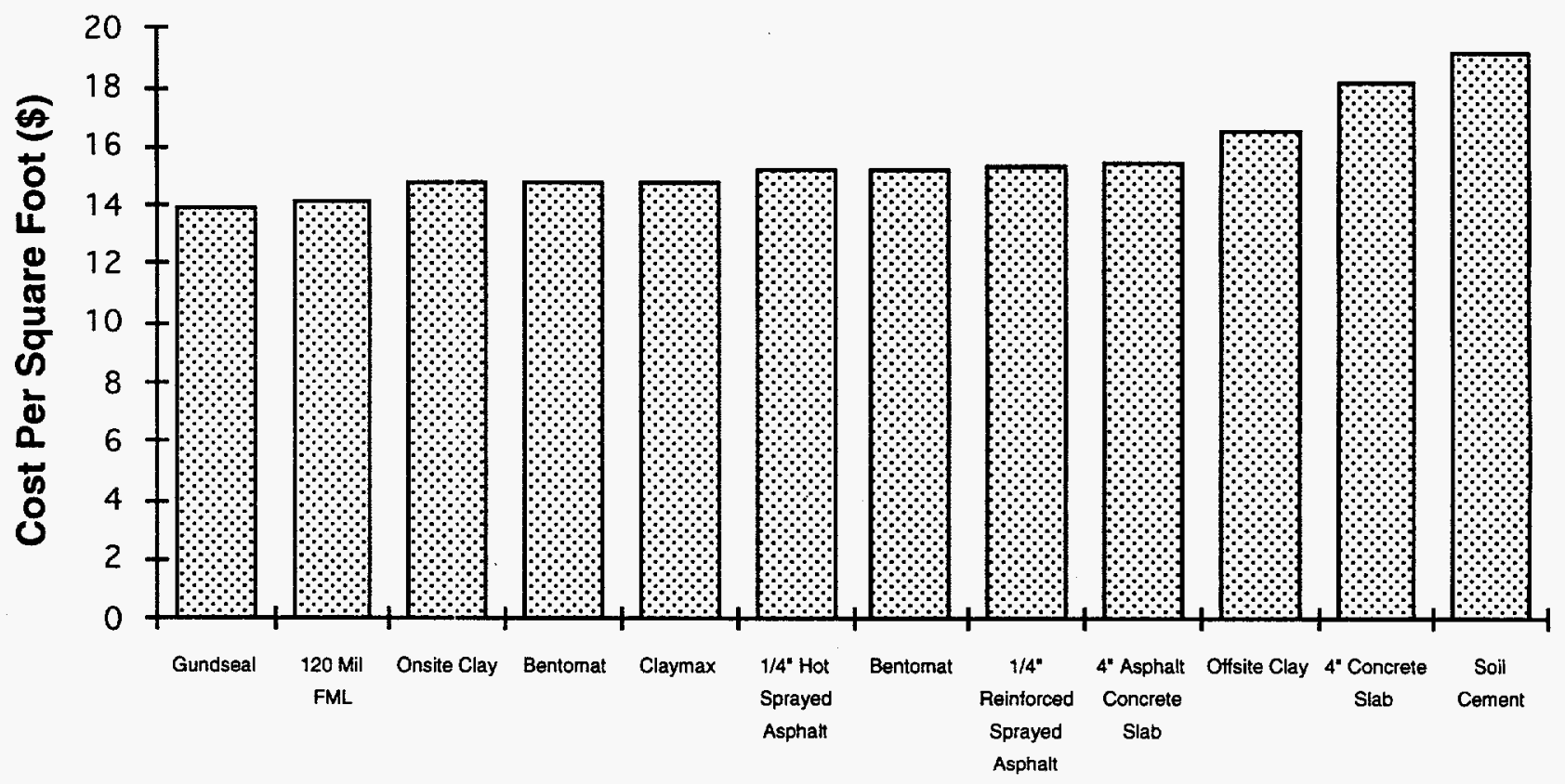

\section{Barrier Materials}

Figure 6-7. Column charts showing barrier material costs for 10-acre site 


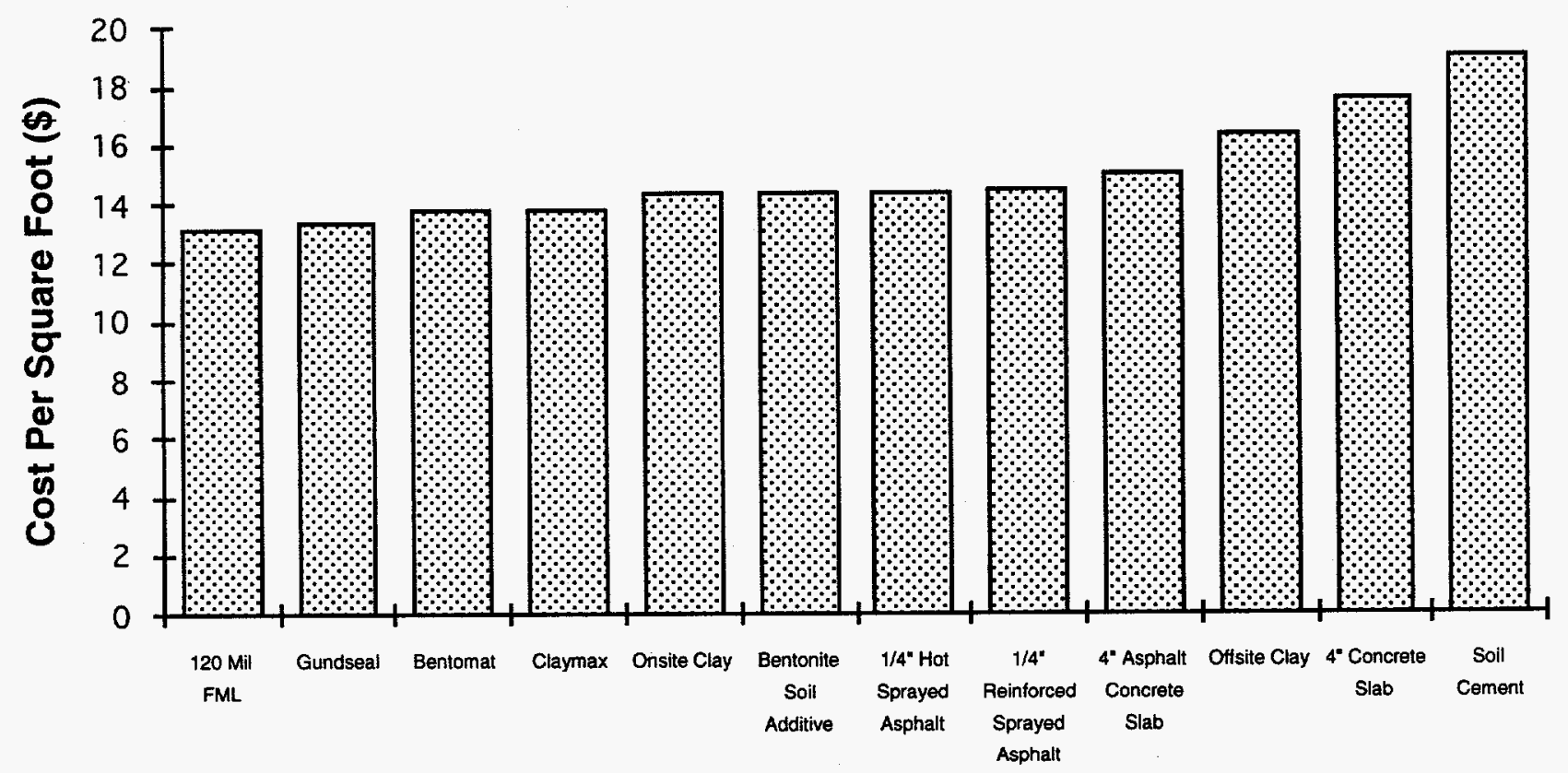

Barrier Materials

Figure 6-8. Column charts showing barrier material costs for 20-acre site 


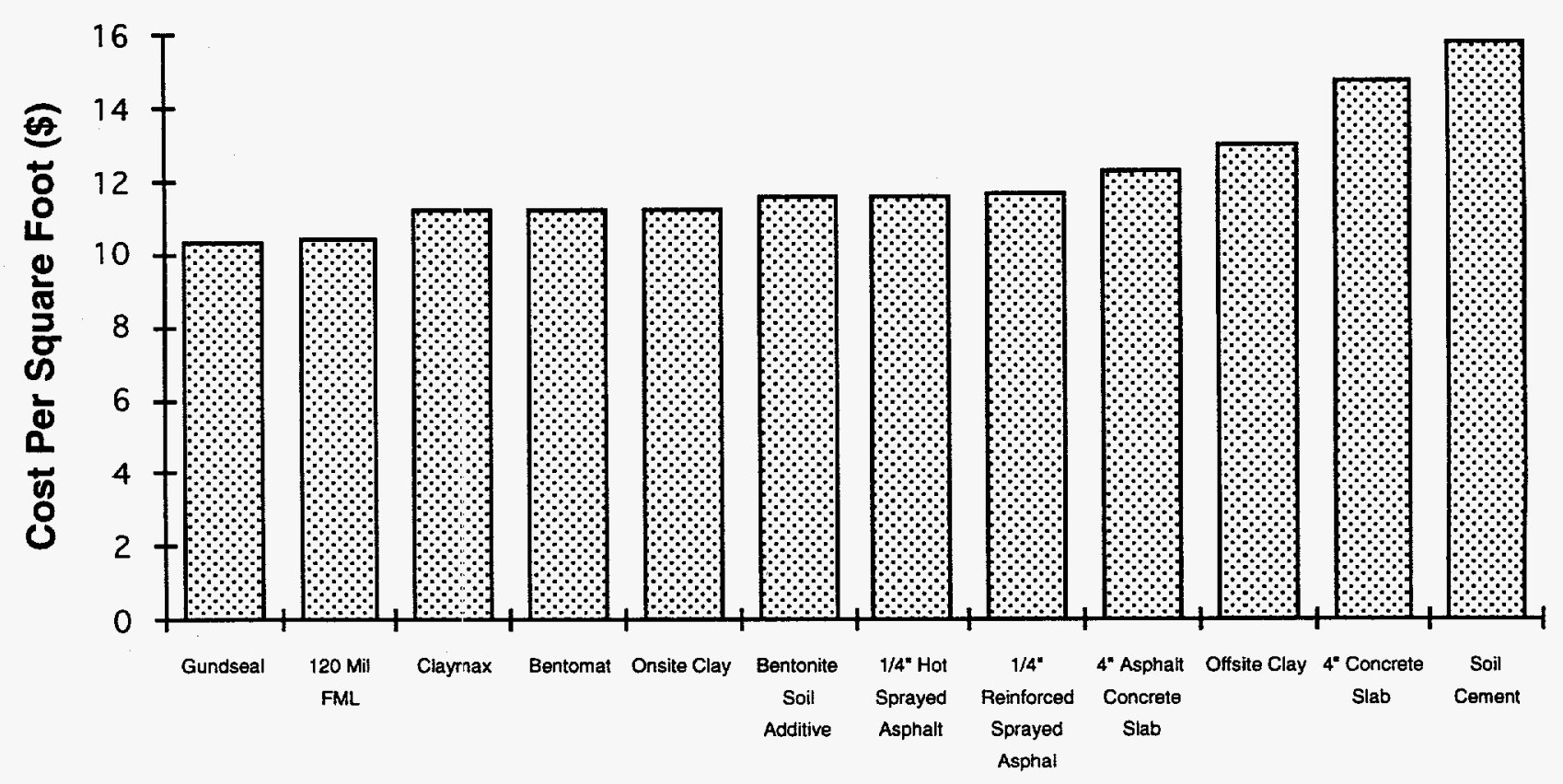

Barrier Materials

Figure 6-9. Column charts showing barrier material costs for 40 -acre site 


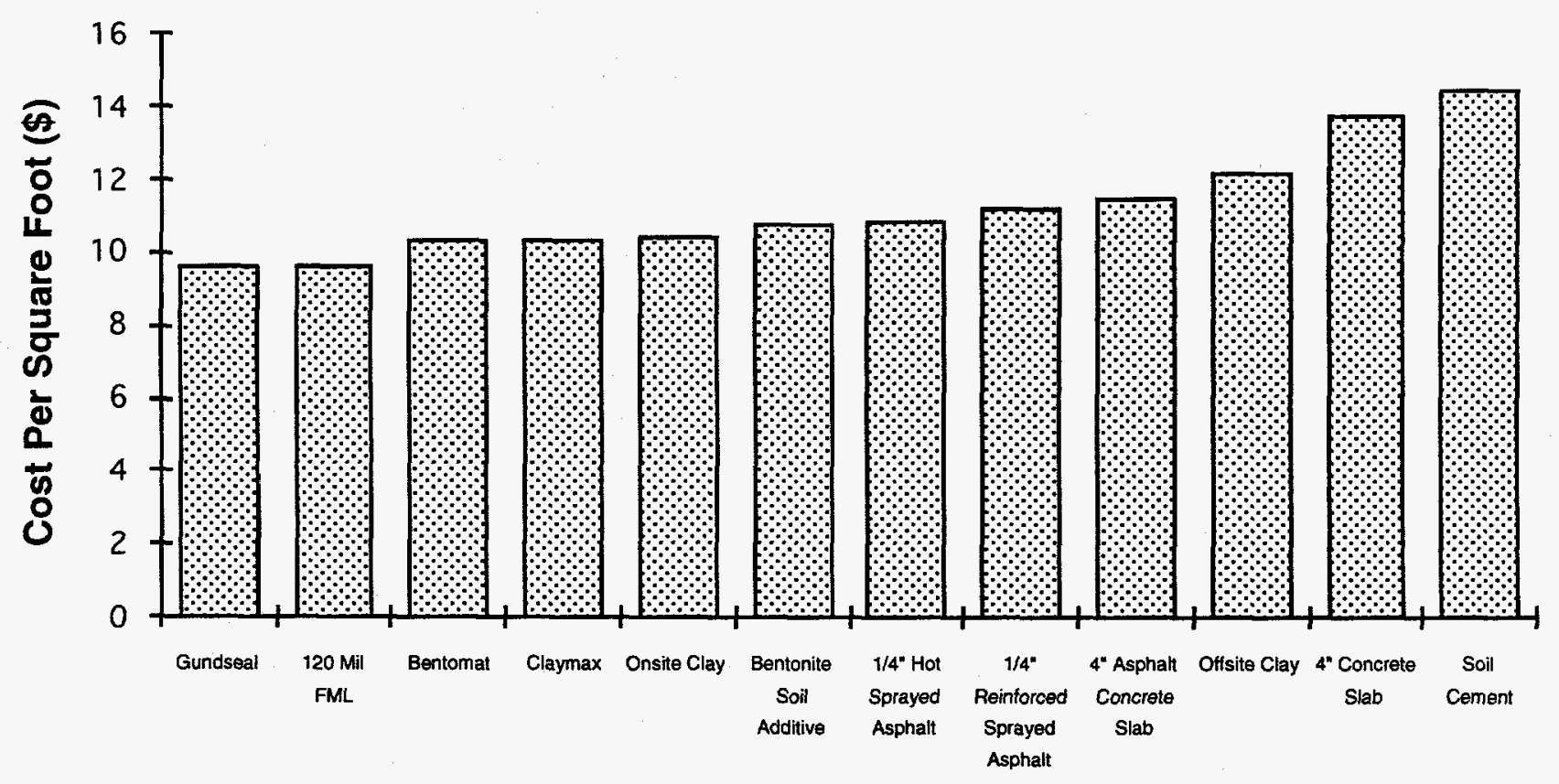

Barrier Materials

Figure 6-10. Column charts showing barrier material costs for 80-acre site 
Borrler Materlats

\begin{tabular}{|c|c|c|}
\hline & $\underline{0,1 \text { Ac Site }}$ & 0.2 Ao Site \\
\hline Claymax & 1.00 & 1.00 \\
\hline Bentomat & 1.00 & 1.00 \\
\hline Gundseal & 1.00 & 1.00 \\
\hline $120 \mathrm{FML}$ & 1.00 & 1.00 \\
\hline Bentonito Additivo & 1.23 & 1.24 \\
\hline Asphalt Concrete & 2.03 & 2.03 \\
\hline Sandy Clay & 1.81 & 1.82 \\
\hline Kaolin Clay & 1.81 & 1.82 \\
\hline Sprayod Asphalt & 1.23 & 2.65 \\
\hline Roint Spray Asphelt & 2.69 & 2.74 \\
\hline Soil Cernent & 3.44 & $3 . \overline{4} 8$ \\
\hline $4^{\text {" Concrete }}$ & 9.37 & 9.43 \\
\hline
\end{tabular}

Relative Man-Hour:

0.5 Ac Site 1.0 Ac Site 2.0 Aa Site 5.0 Ac Site 10.0 Ac Site 20.0 Ac Site 40.0 Ac Sile 80.0 Ac Site

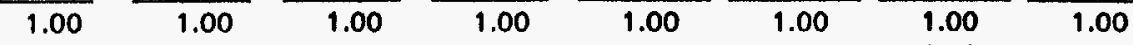

$\begin{array}{llllllll}1.00 & 1.00 & 1.00 & 1.00 & 1.00 & 1.00 & 1.00 & 1.00\end{array}$

$\begin{array}{llllllll}1.00 & 1.00 & 1.00 & 1.00 & 1.00 & 1.00 & 1.00 & 1.00\end{array}$

$\begin{array}{llllllll}1.00 & 1.00 & 1.00 & 1.00 & 1.33 & 1.27 & 1.2 & 1.11\end{array}$

$\begin{array}{llllllll}1.19 & 1.19 & 1.04 & 1.08 & 2.13 & 2.26 & 2.42 & 2.59\end{array}$

$\begin{array}{llllllll}2.03 & 2.02 & 2.02 & 2.02 & 3.42 & 4.06 & 4.49 & 4.68\end{array}$

$\begin{array}{llllllll}1.82 & 1.81 & 1.82 & 1.82 & 3.76 & 4.13 & 4.66 & 5.11\end{array}$

$\begin{array}{llllllll}1.82 & 1.81 & 1.82 & 1.82 & 3.76 & 4.13 & 4.66 & 5.11\end{array}$

$\begin{array}{llllllll}2.64 & 2.64 & 2.64 & 2.64 & 4.63 & 5.25 & 5.5 & 6.42\end{array}$

$\begin{array}{llllllll}2.73 & 2.73 & 2.73 & \cdot 2.73 & 4.72 & 5.35 & 5.6 & 6.54\end{array}$

$\begin{array}{llllllll}3.46 & 3.47 & 3.47 & 3.47 & 5 & 5.48 & 0.07 & 0.77\end{array}$

$\begin{array}{lllllll}3.46 & 3.47 & 3.47 & 3.47 & 5 & 5.48 & 0.07\end{array}$

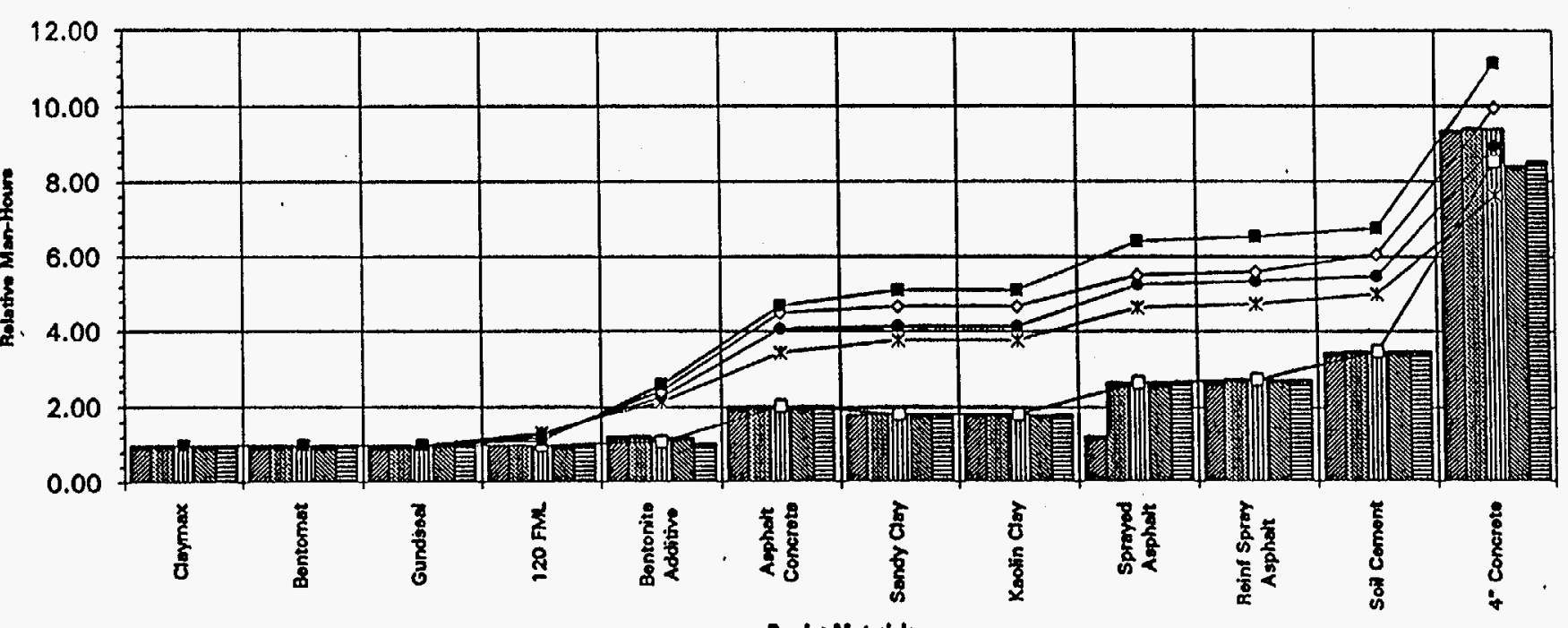

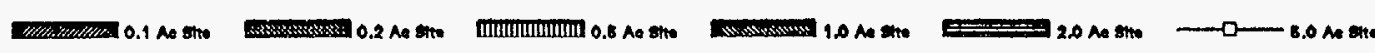

- 
Table 6-2. Estimated Costs ${ }^{(1)}$ For 0.1 Acre Site

\begin{tabular}{|c|c|c|c|c|c|}
\hline Ranking & Barrier Materials & $\begin{array}{l}(2) \\
\text { O\&M } \\
(\$ K)\end{array}$ & $\begin{array}{c}(3) \\
\text { ICC } \\
(\$ K)\end{array}$ & $\begin{array}{l}\text { (4) } \\
\mathrm{PW} \\
(\$ \mathrm{~K})\end{array}$ & $\begin{array}{l}\text { Cost Per } \\
\text { Sq. Ft. } \\
(\$)\end{array}$ \\
\hline 1 & 120 mil-FML & 146 & 253 & 399 & 91.60 \\
\hline 2 & Gundseal $\mathbb{B}$ & 146 & 253 & 399 & 91.60 \\
\hline 3 & 2'-0" compacted clay (onsite) & 151 & 252 & 403 & 92.52 \\
\hline 4 & $1 / 4^{\prime \prime}$ hot sprayed asphalt & 147 & 257 & 404 & 92.75 \\
\hline 5 & Bentonite soil additive & 148 & 256 & 404 & 92.75 \\
\hline 6 & $1 / 4^{\prime \prime}$ reinforced sprayed asphalt & 147 & 258 & 405 & 92.98 \\
\hline 7 & Bentomat ${ }^{\circledR}$ & 147 & 260 & 407 & 93.43 \\
\hline 8 & Claymax ${ }^{\circledR}$ & 147 & 260 & 407 & 93.43 \\
\hline 9 & $2^{\prime}-0^{\prime \prime}$ compacted clay (offsite) & 152 & 260 & 412 & 94.58 \\
\hline 10 & $4^{\prime \prime}$ asphalt concrete slab & 153 & 264 & 417 & 95.73 \\
\hline 11 & 3'-0" compacted soil cement & 152 & 276 & 428 & 98.48 \\
\hline 12 & $4 "$ concrete slab & 155 & 282 & 437 & 100.32 \\
\hline
\end{tabular}

(1) Cost includes costs for material, installation, QA/QC, etc.

(2) O\&M - operation and maintenance costs

(3) ICC - initial construction costs

(4) PW - present worth 
Table 6-3. Estimated Costs ${ }^{(1)}$ For 0.2 Acre Site

\begin{tabular}{|c|c|c|c|c|c|}
\hline Ranking & Barrier Materials & $\begin{array}{c}(2) \\
O \& M \\
(\$ K)\end{array}$ & $\begin{array}{c}(3) \\
\text { ICC } \\
(\$ K)\end{array}$ & $\begin{array}{c}(4) \\
P W \\
(\$ K)\end{array}$ & $\begin{array}{l}\text { Cost Per } \\
\text { Sq. Ft. } \\
(\$)\end{array}$ \\
\hline 1 & $120 \mathrm{mil}-\mathrm{FML}$ & 148 & 345 & 493 & 56.59 \\
\hline 2 & Gundseal & 148 & 345 & 493 & 56.59 \\
\hline 3 & 2'-0" compacted clay (onsite) & 155 & 342 & 497 & 57.05 \\
\hline 4 & Bentonite soil additive & 151 & 350 & 501 & 57.51 \\
\hline 5 & 1/4" hot sprayed asphalt & 149 & 354 & 503 & 57.74 \\
\hline 6 & $1 / 4^{\prime \prime}$ reinforced sprayed asphalt & 150 & 354 & 504 & 57.85 \\
\hline 7 & Bentomat $(\mathbb{B})$ & 149 & 358 & 507 & 58.20 \\
\hline 8 & Claymax ${ }^{\circledR}$ & 149 & 358 & 507 & 58.20 \\
\hline 9 & 2'-0" compacted clay (offsite) & 156 & 360 & 516 & 59.23 \\
\hline 10 & 4" asphalt concrete slab & 158 & 362 & 520 & 59.69 \\
\hline 11 & 3'-0" compacted soil cement & 156 & 389 & 545 & 62.56 \\
\hline 12 & $4 "$ concrete slab & 161 & 399 & 560 & 64.28 \\
\hline
\end{tabular}

(1) Cost includes costs for material, installation, QAVQC, etc.

(2) O\&M - operation and maintenance costs

(3) ICC -- initial construction costs

(4) PW - present worth 
Table 6-4. Estimated Costs ${ }^{(1)}$ For 0.5 Acre Site

\begin{tabular}{|c|c|c|c|c|c|}
\hline Ranking & Barrier Materials & $\begin{array}{l}(2) \\
O \& M \\
(\$ K)\end{array}$ & $\begin{array}{l}(3) \\
\text { ICC } \\
(\$ K)\end{array}$ & $\begin{array}{l}(4) \\
P W \\
(\$ K)\end{array}$ & $\begin{array}{l}\text { Cost Per } \\
\text { Sq. Ft. } \\
\text { (\$) }\end{array}$ \\
\hline 1 & 120 mil-FML & 154 & 605 & 759 & 34.85 \\
\hline 2 & Gundseal $\circledast$ & 154 & 605 & 759 & 34.85 \\
\hline 3 & 2'-0" compacted clay (onsite) & 164 & 596 & 760 & 34.89 \\
\hline 4 & $1 / 4 "$ hot sprayed asphalt & 154 & 623 & 777 & 35.67 \\
\hline 5 & $1 / 4$ " reinforced sprayed asphalt & 155 & 626 & 781 & 35.86 \\
\hline 6 & Bentonite soil additive & 158 & 625 & 783 & 35.95 \\
\hline 7 & Bentomat ${ }^{\circledR}$ & 154 & 636 & 790 & 36.27 \\
\hline 8 & Claymax ${ }^{\circledR}$ & 154 & 636 & 790 & 36.27 \\
\hline 9 & 2'-0" compacted clay (offsite) & 165 & 640 & 805 & 36.96 \\
\hline 10 & 4" asphalt concrete slab & 171 & 639 & 810 & 37.19 \\
\hline 11 & 3'-0" compacted soil cement & 164 & 722 & 886 & 40.68 \\
\hline 12 & $4 "$ concrete slab & 173 & 730 & 903 & 41.46 \\
\hline
\end{tabular}

(1) Cost includes costs for material, installation, QA/QC, etc.

(2) O\&M - operation and maintenance costs

(3) ICC - initial construction costs

(4) PW - present worth 
Table 6-5. Estimated Costs ${ }^{(1)}$ For 1.0 Acre Site

\begin{tabular}{|c|c|c|c|c|c|}
\hline Ranking & Barrier Materials & $\begin{array}{l}(2) \\
O \& M \\
(\$ K)\end{array}$ & $\begin{array}{c}(3) \\
\text { ICC } \\
(\$ K)\end{array}$ & $\begin{array}{l}(4) \\
\mathrm{PW} \\
(\$ \mathrm{~K})\end{array}$ & $\begin{array}{l}\text { Cost Per } \\
\text { Sq. Ft. } \\
(\$)\end{array}$ \\
\hline 1 & 120 mil-FML & 165 & 1,020 & 1,185 & 27.20 \\
\hline 2 & Gundseal $®$ & 165 & 1,020 & 1,185 & 27.20 \\
\hline 3 & $2^{\prime}-0^{\prime \prime}$ compacted clay (onsite) & 181 & 1,008 & 1,189 & 27.30 \\
\hline 4 & $1 / 4 "$ hot sprayed asphalt & 166 & 1,055 & 1,221 & 28.03 \\
\hline 5 & Bentonite soil additive & 172 & 1,052 & 1,224 & 28.21 \\
\hline 6 & $1 / 4 "$ reinforced sprayed asphalt & 167 & 1,062 & 1,229 & 28.21 \\
\hline 7 & Bentomat ${ }^{\circledR}$ & 166 & 1,074 & 1,240 & 28.47 \\
\hline 8 & Claymax $®$ & 166 & 1,074 & 1,240 & 28.47 \\
\hline 9 & 2'-0" compacted clay (offsite) & 181 & 1,090 & 1,271 & 29.18 \\
\hline 10 & $4 "$ asphalt concrete slab & 193 & 1,201 & 1,394 & 32.00 \\
\hline 11 & $4^{\prime \prime}$ concrete slab & 193 & 1,233 & 1,426 & 32.74 \\
\hline 12 & 3'-0" compacted soil cement & 181 & 1,253 & 1,434 & 32.92 \\
\hline
\end{tabular}

(1) Cost includes costs for material, installation, $Q A / Q C$, etc.

(2) O\&M - operation and maintenance costs

(3) ICC - initial construction costs

(4) PW - present worth 
Table 6-6. Estimated Costs ${ }^{(1)}$ For 2.0 Acre Site

\begin{tabular}{|c|c|c|c|c|c|}
\hline Ranking & Barrier Materials & $\begin{array}{c}(2) \\
\text { O\&M } \\
(\$ K)\end{array}$ & $\begin{array}{c}(3) \\
\text { ICC } \\
(\$ K)\end{array}$ & $\begin{array}{c}(4) \\
\mathrm{PW} \\
(\$ \mathrm{~K})\end{array}$ & $\begin{array}{l}\text { Cost Per } \\
\text { Sq. Ft. } \\
(\$)\end{array}$ \\
\hline 1 & 2'-0" compacted clay (onsite) & 224 & 1,787 & 2,011 & 23.08 \\
\hline 2 & Gundseal® & 196 & 1,829 & 2,025 & 23.24 \\
\hline 3 & 120 mil-FML & 196 & 1,829 & 2,025 & 23.24 \\
\hline 4 & $1 / 4^{\prime \prime}$ hot sprayed asphalt & 198 & 1,893 & 2,091 & 24.00 \\
\hline 5 & Bentonite soil additive & 208 & 1,871 & 2,079 & 23.86 \\
\hline 6 & $1 / 4^{\prime \prime}$ reinforced sprayed asphalt & 199 & 1,926 & 2,125 & 24.39 \\
\hline 7 & Claymax $®$ & 198 & 1,931 & 2,129 & 24.44 \\
\hline 8 & Bentomat ${ }^{\circledR}$ & 198 & 1,931 & 2,129 & 24.44 \\
\hline 9 & $2^{\prime}-0 "$ compacted clay (offsite) & 227 & 1,967 & 2,194 & 25.18 \\
\hline 10 & $4 "$ asphalt concrete slab & 234 & 1,936 & 2,170 & 24.91 \\
\hline 11 & 3'-0" compacted soil cement & 226 & 2,290 & 2,516 & 28.88 \\
\hline 12 & $4 "$ concrete slab & 245 & 2,229 & 2,474 & 28.40 \\
\hline
\end{tabular}

(1) Cost includes costs for material, installation, QA/QC, etc.

(2) O\&M - operation and maintenance costs

(3) ICC - initial construction costs

(4) PW - present worth 
Table 6-7. Estimated Costs ${ }^{(1)}$ For 5.0 Acre Site

\begin{tabular}{|c|c|c|c|c|c|}
\hline Ranking & Barrier Materials & $\begin{array}{l}(2) \\
\text { O\&M } \\
(\$ K)\end{array}$ & $\begin{array}{c}(3) \\
\text { ICC } \\
(\$ \mathrm{~K})\end{array}$ & $\begin{array}{c}(4) \\
\mathrm{PW} \\
(\$ \mathrm{~K})\end{array}$ & $\begin{array}{l}\text { Cost Per } \\
\text { Sq. Ft. } \\
(\$)\end{array}$ \\
\hline 1 & 2'-0" compacted clay (offsite) & 318 & 4,135 & 4,453 & 20.45 \\
\hline 2 & 120 mil-FML & 261 & 4,240 & 4,501 & 20.67 \\
\hline 3 & Gundseal® & 261 & 4,240 & 4,501 & 20.67 \\
\hline 4 & Bentonite soil additive & 286 & 4,374 & 4,660 & 21.40 \\
\hline 5 & $1 / 4^{\prime \prime}$ hot sprayed asphalt & 264 & 4,398 & 4,662 & 21.40 \\
\hline 6 & $1 / 4$ " reinforced sprayed asphalt & 267 & 4,436 & 4,703 & 21.59 \\
\hline 7 & Bentomat $\AA$ & 264 & 4,494 & 4,758 & 21.85 \\
\hline 8 & Claymax ${ }^{\circledR}$ & 264 & 4,494 & 4,758 & 21.85 \\
\hline 9 & 4" asphalt concrete slab & 283 & 4,481 & 4,764 & 21.87 \\
\hline 10 & 2'-0" compacted clay (onsite) & 322 & 5,011 & 5,333 & 24.49 \\
\hline 11 & $4 "$ concrete slab & 344 & 5,213 & 5,557 & 25.51 \\
\hline 12 & $3^{\prime}-0^{\prime \prime}$ compacted soil cement & 321 & 5,391 & 5,712 & 26.23 \\
\hline
\end{tabular}

(1) Cost includes costs for material, installation, QA/QC, etc.

(2) O\&M - operation and maintenance costs

(3) ICC - initial construction costs

(4) PW - present worth 
Table 6-8. Estimated Costs ${ }^{(1)}$ For 10.0 Acre Site

\begin{tabular}{|c|c|c|c|c|c|}
\hline Ranking & Barrier Materials & $\begin{array}{c}(2) \\
\text { O\&M } \\
(\$ K)\end{array}$ & $\begin{array}{c}(3) \\
\text { ICC } \\
(\$ K)\end{array}$ & $\begin{array}{c}\text { (4) } \\
\mathrm{PW} \\
(\$ \mathrm{~K})\end{array}$ & $\begin{array}{l}\text { Cost Per } \\
\text { Sq. Ft. } \\
\text { (\$) }\end{array}$ \\
\hline 1 & Gundseal $\otimes$ & 339 & 5,712 & 6,051 & 13.89 \\
\hline 2 & 120 mil-FML & 339 & 5,788 & 6,127 & 14.07 \\
\hline 3 & $2^{\prime}-0$ " compacted clay (onsite) & 429 & 6,023 & 6,452 & 14.81 \\
\hline 4 & Bentomat ${ }^{\circledR}$ & 345 & 6,120 & 6,465 & 14.84 \\
\hline 5 & Claymax ${ }^{\circledR}$ & 345 & 6,120 & 6,465 & 14.84 \\
\hline 6 & $1 / 4 "$ hot sprayed asphalt & 345 & 6,304 & 6,649 & 15.26 \\
\hline 7 & Bentonite soil additive & 379 & 6,291 & 6,670 & 15.31 \\
\hline 8 & $1 / 4^{\prime \prime}$ reinforced sprayed asphalt & 349 & 6,353 & 6,702 & 15.39 \\
\hline 9 & 4" asphalt concrete slab & 420 & 6,346 & 6,766 & 15.53 \\
\hline 10 & $2^{\prime}-0^{\prime \prime}$ compacted clay (offsite) & 434 & 6,846 & 7,280 & 16.71 \\
\hline 11 & 4" concrete slab & 502 & 7,395 & 7,897 & 18.13 \\
\hline 12 & $3^{\prime}-0^{\prime \prime}$ compacted soil cement & 434 & 7,944 & 8,378 & 19.23 \\
\hline
\end{tabular}

(1) Cost includes costs for material, installation, QA/QC, etc.

(2) O\&M - operation and maintenance costs

(3) ICC - initial construction costs

(4) PW - present worth 
Table 6-9. $\quad$ Estimated Costs $^{(1)}$ For 20.0 Acre Site

\begin{tabular}{|c|c|c|c|c|c|}
\hline Ranking & Barrier Materials & $\begin{array}{l}(2) \\
O \& M \\
(\$ K)\end{array}$ & $\begin{array}{l}(3) \\
\text { ICC } \\
(\$ K)\end{array}$ & $\begin{array}{l}\text { (4) } \\
\text { PW } \\
\text { (\$K) }\end{array}$ & $\begin{array}{l}\text { Cost Per } \\
\text { Sq. Ft. } \\
(\$)\end{array}$ \\
\hline 1 & 120 mil-FML & 519 & 10,841 & 11,360 & 13.04 \\
\hline 2 & Gundseal ${ }^{\circledR}$ & 519 & 11,023 & 11,542 & 13.25 \\
\hline 3 & Bentomat $(\AA$ & 527 & 11,481 & 12,008 & 13.78 \\
\hline 4 & Claymax ${ }^{\circledR}$ & 527 & 11,481 & 12,008 & 13.78 \\
\hline 5 & $2^{\prime}-0^{\prime \prime}$ compacted clay (onsite) & 649 & 11,814 & 12,463 & 14.31 \\
\hline 6 & Bentonite soil additive & 575 & 11,905 & 12,480 & 14.33 \\
\hline 7 & $1 / 4^{\prime \prime}$ hot sprayed asphalt & 527 & 11,980 & 12,507 & 14.36 \\
\hline 8 & $1 / 4^{\prime \prime}$ reinforced sprayed asphalt & 533 & 12,076 & 12,609 & 14.47 \\
\hline 9 & 4" asphalt concrete slab & 661 & 12,300 & 12,961 & 14.88 \\
\hline 10 & $2^{\prime}-0^{\prime \prime}$ compacted clay (offsite) & 655 & 13,504 & 14,159 & 16.25 \\
\hline 11 & 4" concrete slab & 779 & 14,341 & 15,120 & 17.36 \\
\hline 12 & $3^{\prime}-0^{\prime \prime}$ compacted soil cement & 655 & 15,913 & 16,568 & 19.02 \\
\hline
\end{tabular}

(1) Cost includes costs for material, installation, QA/QC, etc.

(2) $\mathrm{O} \& \mathrm{M}$ - operation and maintenance costs

(3) ICC -- initial construction costs

(4) PW - present worth 
Table 6-10. Estimated Costs ${ }^{(1)}$ For 40.0 Acre Site

\begin{tabular}{|c|l|c|c|c|c|}
\hline Ranking & \multicolumn{1}{|c|}{ Barrier Materials } & $\begin{array}{c}(2) \\
\text { O\&M } \\
(\$ \mathrm{~K})\end{array}$ & $\begin{array}{c}(3) \\
\text { ICC } \\
(\$ \mathrm{~K})\end{array}$ & $\begin{array}{c}(4) \\
\mathbf{P W} \\
(\$ \mathrm{~K})\end{array}$ & $\begin{array}{c}\text { Cost Per } \\
\text { Sq. Ft. } \\
(\$)\end{array}$ \\
\hline 1 & Gundseal ${ }^{\circledR}$ & 1,025 & 16,832 & 17,857 & 10.25 \\
\hline 2 & 120 mil-FML & 1,025 & 16,975 & 18,000 & 10.33 \\
\hline 3 & Claymax ${ }^{\circledR}$ & 1,036 & 18,249 & 19,285 & 11.07 \\
\hline 4 & Bentomat ${ }^{\circ}$ & 1,036 & 18,250 & 19,286 & 11.07 \\
\hline 5 & $2^{\prime}-0^{\prime \prime}$ compacted clay (onsite) & 1,196 & 18,148 & 19,344 & 11.10 \\
\hline 6 & Bentonite soil additive & 1,099 & 18,989 & 20,088 & 11.53 \\
\hline 7 & $1 / 4 "$ hot sprayed asphalt & 1,036 & 19,135 & 20,171 & 11.58 \\
\hline 8 & $1 / 4 "$ reinforced sprayed asphalt & 1,043 & 19,310 & 20,353 & 11.68 \\
\hline 9 & $4^{\prime \prime}$ asphalt concrete slab & 1,275 & 20,170 & 21,445 & 12.31 \\
\hline 10 & $2^{\prime}-0^{\prime \prime}$ compacted clay (offsite) & 1,205 & 21,343 & 22,548 & 12.94 \\
\hline 11 & $4^{\prime \prime}$ concrete slab & 1,431 & 24,288 & 25,719 & 14.76 \\
\hline 12 & $3^{\prime}-0^{\prime \prime}$ compacted soil cement & 1,205 & 26,252 & 27,457 & 15.76 \\
\hline
\end{tabular}

(1) Cost includes costs for material, installation, $Q A / Q C$, etc.

(2) O\&M - operation and maintenance costs

(3) ICC - initial construction costs

(4) PW - present worth 
Table 6-1.1. Estimated Costs ${ }^{(1)}$ For 80.0 Acre Site

\begin{tabular}{|c|c|c|c|c|c|}
\hline Ranking & Barrier Materials & $\begin{array}{c}(2) \\
O \& M \\
(\$ K)\end{array}$ & $\begin{array}{c}(3) \\
\text { ICC } \\
(\$ K)\end{array}$ & $\begin{array}{c}(4) \\
\mathrm{PW} \\
(\$ \mathrm{~K})\end{array}$ & $\begin{array}{l}\text { Cost Per } \\
\text { Sq. Ft. } \\
\text { (\$) }\end{array}$ \\
\hline 1 & Gundseal ${ }^{\circledR}$ & 1,605 & 31,800 & 33,405 & 9.59 \\
\hline 2 & 120 mil-FML & 1,605 & 31,869 & 33,474 & 9.61 \\
\hline 3 & Bentomat ${ }^{\circledR}$ & 1,617 & 34,410 & 36,027 & 10.34 \\
\hline 4 & Claymax $®$ & 1,617 & 34,410 & 36,027 & 10.34 \\
\hline 5 & $2^{\prime}-0^{\prime \prime}$ compacted clay (onsite) & 1,807 & 34,307 & 36,114 & 10.36 \\
\hline 6 & Bentonite soil additive & 1,693 & 36,243 & 37,936 & 10.89 \\
\hline 7 & $1 / 4 "$ hot sprayed asphalt & 1,617 & 36,588 & 38,205 & 10.96 \\
\hline 8 & $1 / 4$ " reinforced sprayed asphalt & 1,628 & 36,949 & 38,577 & 11.07 \\
\hline 9 & 4" asphalt concrete slab & 2,053 & 37,711 & 39,764 & 11.41 \\
\hline 10 & $2^{\prime}-0^{\prime \prime}$ compacted clay (offsite) & 1,817 & 40,508 & 42,325 & 12.15 \\
\hline 11 & $4 "$ concrete slab & 2,235 & 45,864 & 48,099 & 13.80 \\
\hline 12 & $3^{\prime}-0^{\prime \prime}$ compacted soil cement & 1,816 & 48,786 & 50,602 & 14.52 \\
\hline
\end{tabular}

(1) Cost includes costs for material, installation, QA/QC, etc.

(2) O\&M - operation and maintenance costs

(3) ICC - initial construction costs

(4) PW - present worth 


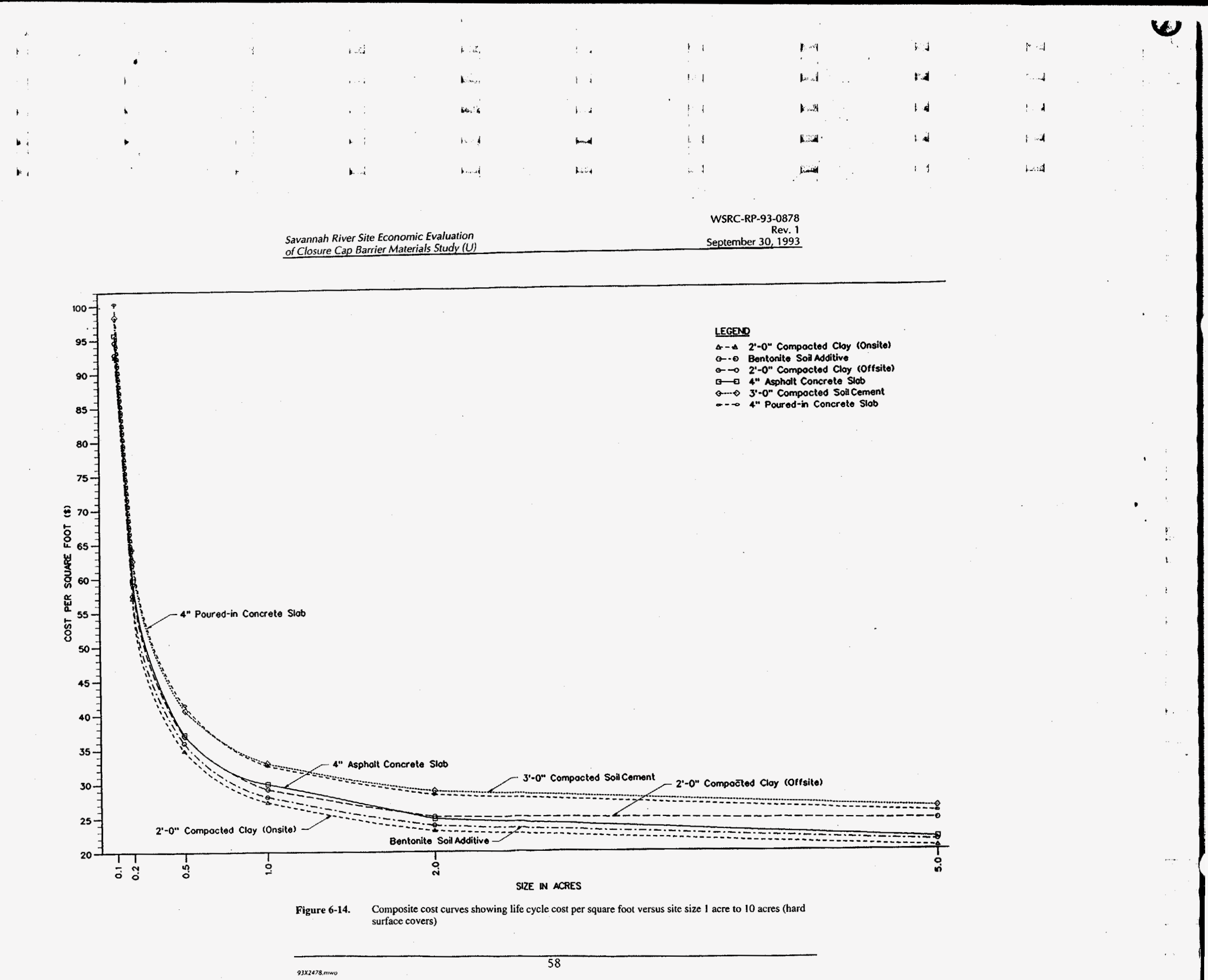
$27 \geq \geq 1$

$\therefore=1$

1:13:1

ב :

$$
\text { ะ } \geq \geq
$$

$\therefore=z$

$\therefore: 1 I$

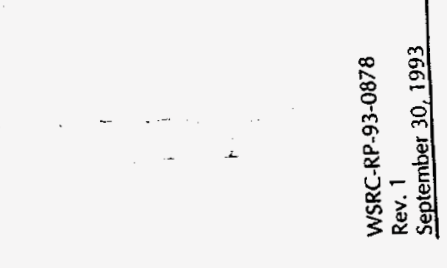

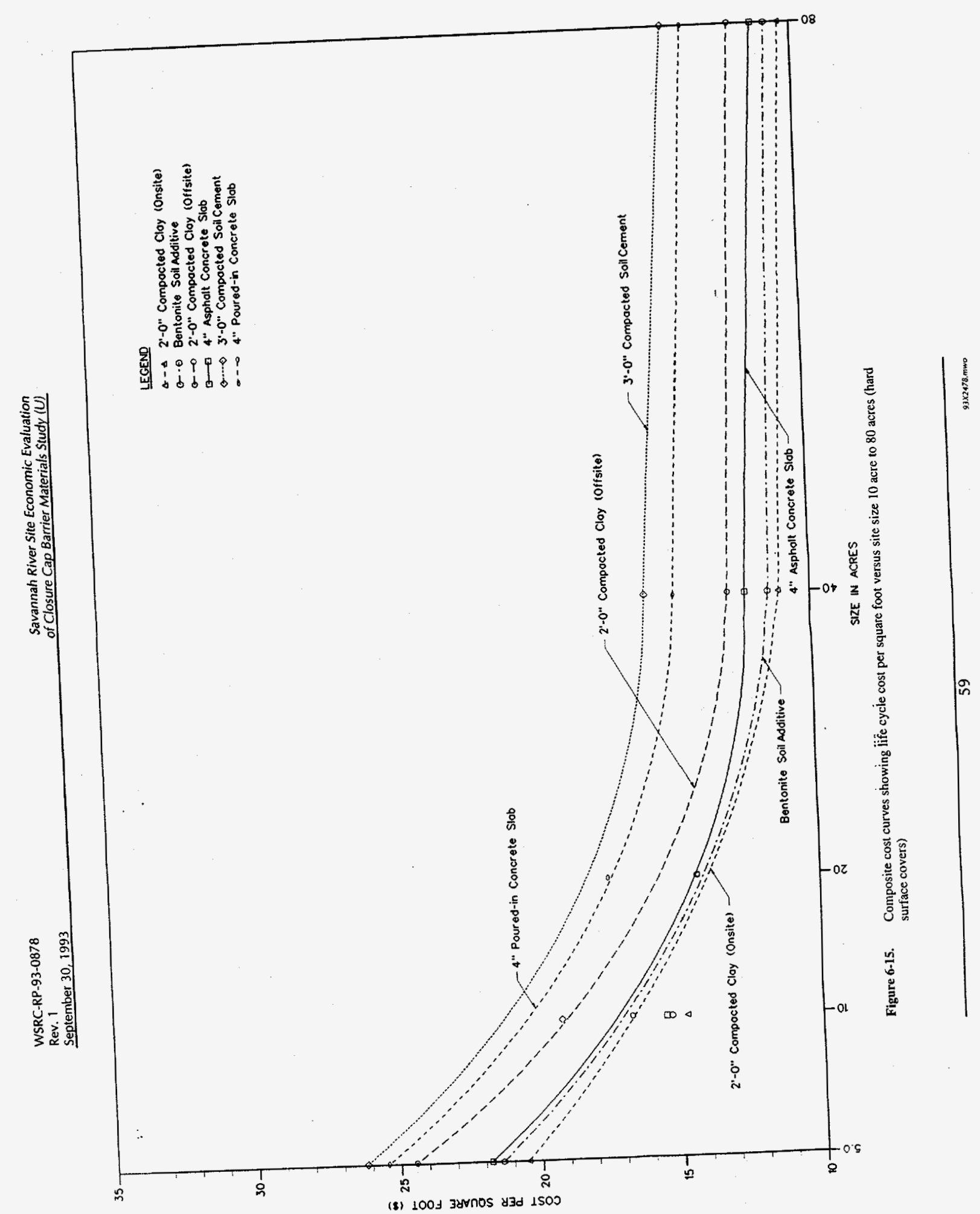




\subsection{Discussion}

The cost comparisons discussed in Section 6.2 reveal that for all SRS waste sites and for all 10 considered for evaluation ( 0.1 acre to 80 acres), Gundseal ${ }^{\circledR}$ and 120 -mil FML prove to be the most cost-effective materials for covering the sites. This is primarily because of the low material placement and maintenance costs of these barrier materials. Additionally, for establishing the cover system design for either of these two materials, no flexible membrane liner (30-mil FML) was utilized. These factors also contributed in lowering the costs of these cover systems thus, making them the most cost-effective. However, considering other factors, such as rupturing during construction, comparatively, Gundseal ${ }^{\circledR}$ offers better protection. If 120-mil FML becomes ruptured by sharp objects or heavy equipment during construction, the entire cover system will become less effective. In the absence of a secondary system (30-mil FML), the cover system will not be able to resist the flow of leachate into the waste materials buried underneath.

Gundseal ${ }^{\circledR}$ also offers a better option for waste sites subjected to subsidence. A recent study conducted by Bhutani and Mead ${ }^{6}$ revealed that substituting a geosynthetic clay liner for a two-foot compacted clay cover system considerably reduced the amount of dead load to be carried over a void resulting from subsidence. Reinforcing the geosynthetic clay liner with an extra layer of geogrid further enhanced the ability of the cover system to span several times larger voids.

The next most-effective barrier materials for site sizes 0.1 acre to 10 acres are onsite compacted clay, bentonite soil additive, and 1/4-inch-thick hot sprayed asphalt. For site sizes 10 acres to 80 acres, the next most cost-effective barrier materials are Claymax $®$, Bentomat ${ }^{\circledR}$, and onsite compacted clay. Considering other aspects such as resistance to subsidence, a cover system utilizing asphalt as a hydraulic barrier cannot withstand soil subsidence without cracking. The cover system utilizing hot sprayed asphalt can also be ruptured easily by sharp objects during construction and can also degrade in sunlight. Asphalt also offers poor resistance to oils and organic solvents and can degrade when exposed to sunlight during construction. Although asphalt has been used extensively for many years as a waterproofing agent, its utilization as a hydraulic barrier material for waste sites has not been well established. Because of these reasons, 1/4-inch-thick hot sprayed asphalt, as well as reinforced sprayed asphalt, are not recommended as barrier materials for SRS waste sites. The bentonite soil additive is also not recommended. The soil additives require a rigorous mixing effort and close supervision and control to ensure that the mixture is prepared in the exact specified ratios and moisture contents.

A close review of the composite cost curves shown in Figures 6-12 through 6-15 reveals that the costs for onsite compacted clay are slightly lower than those of the Bentomat $\circledast$ and Claymax ${ }^{\circledR}$ for 0.1 -acre to 10 -acre sites. However, the costs for onsite compacted clay are higher than those of Bentomat ${ }^{\circledR}$ and Claymax ${ }^{\circledR}$ for sites larger than 10 acres. The primary reasons for onsite sandy clay being less expensive is that there are no material costs involved, and there is an insignificant affect on cost because of the smaller project duration factor. Furthermore, the small sites, especially smaller then 10 acres, would require relatively small quantities of soil to be compacted and, thus, result in lower compaction costs. Because of these reasons, the onsite compacted sandy clay appears to be a viable solution for covering the small waste sites when only cost is considered. However, onsite compacted sandy clay does not offer a good solution for cover systems subjected to subsidence.

Claymax ${ }^{\circledR}$ and Bentomat ${ }^{\circledR}$ are both geosynthetic clay liners and, like Gundseal $®$, are manufactured with good quality control and are easy to field construct. The man-hours analysis conducted by this study also shows that when project duration factors are taken into account, both Claymax ${ }^{\circledR}$ and Bentomat ${ }^{\circledR}$ can result in large savings because of less 
construction time and improvement in quality assurance. If these factors are taken into account, both Claymax and Bentomat become more cost-effective and rank next to Gundseal ${ }^{\circledR}$. Presently, both of these materials are the subject of much research. The results of the recently conducted research for both materials has also revealed that both materials can withstand subsidence, while maintaining the required permeability. Additionally, both Claymax and Bentomat ${ }^{\circledR}$ can be engineered during construction with a greater degree of confidence and require less engineering costs than barrier materials requiring soil mixing and compaction. In terms of per-square-foot cost, both Claymax and Bentomat, on the average, cost approximately $\$ 1.00-\$ 2.00$ per square foot more than Gundseal $\circledast$ for waste sites between 0.1 acre and 10 acres and $\$ 0.50$ to $\$ 1.00$ for waste sites 10 acres to 80 acres.

Both soil cement and concrete slab utilize Portland cement, which is relatively expensive when compared to other natural materials such as onsite or offsite clay. Additionally, concrete requires higher maintenance costs because of its natural tendency to develop cracks when subjected to tensile stresses. Depending upon the site size, these materials will cost approximately $\$ 5.00$ - $\$ 10.00$ per square foot more than Gundseal ${ }^{\circledR}$. Even if the soil cement and concrete slab were more competitive in cost, these may not be suitable barrier materials because of their inherent property of cracking at low-tensile stresses and strains.

Asphalt concrete is usually used for paving roads. For construction purposes, both the hot asphalt and aggregates are mixed in required proportions, spread on the subgrade surface by highway spreaders, and compacted. The handling of high softening point asphalt requires special skills and planning to prevent the material from cooling and clogging the hose lines and spray bars, especially during cold weather. Asphalt concrete costs more than Gundseal ${ }^{\circledR}$ and can also easily crack under tensile strains produced by subsidence. Because of the susceptibility of cracking and constant maintenance, asphalt concrete is also not recommended as a barrier material for SRS waste sites.

From the above discussion, it is apparent that the most appropriate and cost-effective barrier material for covering SRS sites would be a composite of a geosynthetic clay liner, a 30-mil FML, and onsite clay. The composite cover system would also require a foundation layer made of onsite soil compacted to $95 \%$ of standard proctor moisture-density relationship per ASTM D698-78. The compaction of the foundation layer would minimize the settlement and provide an additional hydraulic barrier. The permeability of the foundation layer and that of the geosynthetic clay liner provide the composite permeability of the entire cover system. However, the effectiveness of the foundation layer and its impact on the composite permeability of the cover system should be investigated by field tests.

Some sites at SRS can be categorized as shallow (with depths less than three feet) or small flat areas. Examples include SRL 904-A Process Trench (depth 2.7 feet), M-Area West (two small sites each with approximately a 200-square-feet area), and Over Flow Basin (108-4R) (75 feet $x 75$ feet $x 2.5$ feet in depth). For this category of sites, with minimal potential for subsidence, covering the site with a two-foot layer of compacted onsite clay would be most appropriate and cost-effective. 


\subsection{Conclusions/Recommendations}

\subsection{Conclusions}

The most cost-effective barrier material configuration for a closure cover system for SRS waste sites is a composite geosynthetic clay liner. This configuration provides a redundant hydraulic barrier, along with a compacted sandy clay soil for structural strength and provides a low material cost. The composite geosynthetic clay liner cover system meets and exceeds the RCRA/CERCLA requirements.

The results of the economic evaluation based on project size are grouped into two parts:

- Group 1: 0.1 acres to 10 acres

- Group 2: 10 acres to 80 acres.

The most cost-effective barrier material(s) for Group 1 are Gundseal 8,120 -mil HDPE-FML, and onsite sandy clay geosynthetic composite. The material cost per-square-foot for Gundseal ${ }^{\circledR}$ ranges from $\$ 91.60$ per square foot for 0.1 -acre sites to $\$ 13.89$ per square foot for 10 -acre sites. The material cost per square foot for 120-mil HDPE-FML ranges from $\$ 91.60$ per square foot for 0.1 -acre sites to $\$ 14.07$ per square foot for 10 -acre sites. The material cost per square foot for onsite sandy clay geosynthetic composite ranges from $\$ 92.52$ per square foot for 0.1 -acre sites to $\$ 14.81$ per square foot for 10-acre sites.

The most cost-effective barrier material(s) for Group 2 are Gundseal ${ }^{\circledR}$ and 120-mil FML. The material cost per square foot for Gundseal ${ }^{\circledR}$ ranges from $\$ 13.89$ for 10 -acre sites to $\$ 9.59$ for 80 -acre sites. The material cost per square foot for 120 mil-FML ranges from $\$ 14.07$ for 10 acre sites to $\$ 9.61$ for 80 -acre sites.

The other two geosynthetic clay liners considered in this study, Claymax $\circledast$ and Bentomat ( are slightly higher in cost primarily because of the additional material cost of the 30-mil FML. However, this additional material cost overshadows any indirect cost savings from project duration, reparability, and overall effectiveness because of a redundant hydraulic barrier. These remaining geosynthetic clay liners provide the same performance characteristics as the Gundseal $\otimes$ configuration and accommodate a redundant hydraulic barrier configuration. The per-square-foot costs are:

- Claymax: $\$ 93.43$ for 0.1 -acre sites, $\$ 14.84$ for 10 -acre sites, and $\$ 10.34$ for 80 -acre sites

- Bentomat $\AA^{\circledR}$ : $\$ 93.43$ for 0.1 -acre sites, $\$ 14.84$ for 10 -acre sites, and $\$ 10.34$ for 80 -acre sites.

Barrier material cost-effectiveness and project duration are impacted by whether the barrier material is manufactured or constructed in place. A breakpoint among the project sizes evaluated was at 10 acres. Below 10 acres sites, the project duration's impact was insignificant on the overall project cost and the total project cost is directly related to material cost considering all other factors as same. Above 10 acres sites, both material cost and the project duration's impact was significant on the overall project cost considering all other factors as same. 


\subsection{Recommendations}

It is recornmended that a composite cover system configuration be a primary configuration of consideration for a cover system. The composite geosynthetic clay liners configurations are recommended. However, the foundation layer must be constructed to provide, not only a structural foundation for the system, but also to contribute to the hydraulic barrier capacity of the overall cover system. Test pads field investigations are recommended to verify these performance characteristics.

Deviations from established cover system configurations, i.e., EPA configuration, require regulatory approval. It is recommended that regulatory consultation be sought during the screening of alternative configurations.

For smaller waste sites with little potential for subsidence, the recommended cover system is a compacted onsite sandy clay with a 30-mil FML configuration. The compacted sandy clay soil must be of a quality to contribute to the hydraulic barrier capacity of the cover system.

Several waste site closure projects are either ongoing or are scheduled to be completed in the upcoming years. The cost data generated from these future projects will be tracked and entered in to a cost-estimating database. It is recommended that at some future date, this study be revised to reflect actual costs encountered for constructing various closure projects at SRS. 


\subsection{References}

1. Bhutani, J. S., et al., "Economic Evaluation of Closure Cap Barrier Materials, " US DOE Report WSRC-RP-93-0878, Rev. 0, Westinghouse Savannah River Company, Aiken, SC, June 1993.

2. Bhutani, J. S., et al., "Closure Cap Barrier Materials Evaluation Study - Phase I," US DOE Report WSRC-RP-91-1288, Rev. 0, Westinghouse Savannah River Company, Aiken, SC, May 1992.

3. Personal Telephone Contact with Scott Ortolon of Gundle on May 27, 1992; Telephone (713) 443-8564.

4. Personal Telephone Contact with Bob Traugher of Bentomat on May 27, 1992; Telephone (708) 392-5800.

5. Personal Telephone Contact with Representative of Claymax on May 27, 1992.

6. Bhutani, J. S., and Mead, S. M.; "Alternative Study of Potential Cover Systems for the Sanitary Landfill (740-G), Savannah River Site, "US DOE Report WSRC-TR-92-194, Rev. 0, Westinghouse Savannah River Company, Aiken, SC, April 1992. 
APPENDICES 


\section{Appendix A}

Cover System Configurations and Major Activities Involved in the Construction of Individual Cover Systems 


\section{Appendix A-1}

Major Construction Activities for a Typical One-Acre Waste Site 


\section{A.1 Major Construction Activities for the Construction of a Typical 1-Acre Waste Site.}

Basically the major construction activities for a cover system will follow three phases:

- $\quad$ site preparation

- cover system construction

- postclosure

\section{A.1.1 Site Preparation}

Construction activities for site preparation would possibly include the following:

- clearing and grubbing

- demolishing existing structures

- precontouring the site

- placing of erosion controls during construction

- establishing of support facilities

- constructing of access roads and excess soil stockpiles

- proper placing of construction warning signs

\section{A.1.1.1 Clearing and Grubbing}

Clearing and grubbing are generally continual operations. Ideally, the clearing and grubbing operations should not proceed so far in advance of the construction operations that large denuded areas are that later on could cause erosion and/or develop slope-stability problems.

\section{A.1.1.2 Demolition of Existing Structures}

Some sites may involve the removal and disposal of certain facility items such as piping for overflow channels between seepage basins or the removal of a security fence in order to start construction.

\section{A.1.1.3 Precontouring the Site}

Precontouring the site involves establishing a uniform grade across the site (refer to Figure A1) (or portion of the site) as part of the surface water management plan (SWMP) or to provide a stable, suitable working surface from which to begin construction operations. The slope(s) established in this operation may or may not parallel the site's final contours. Precontouring the site may involve removing an area or layer of soil that is potentially troublesome, such as a layer of sandy soil or peat at the ground surface.

\section{A.1.1.4 Erosion and Sediment Control During Construction}

This involves the placing of silt fences, straw-bale dikes, or sedimentation basins to control the transport of sediment, sand, and silt disturbed during construction. 


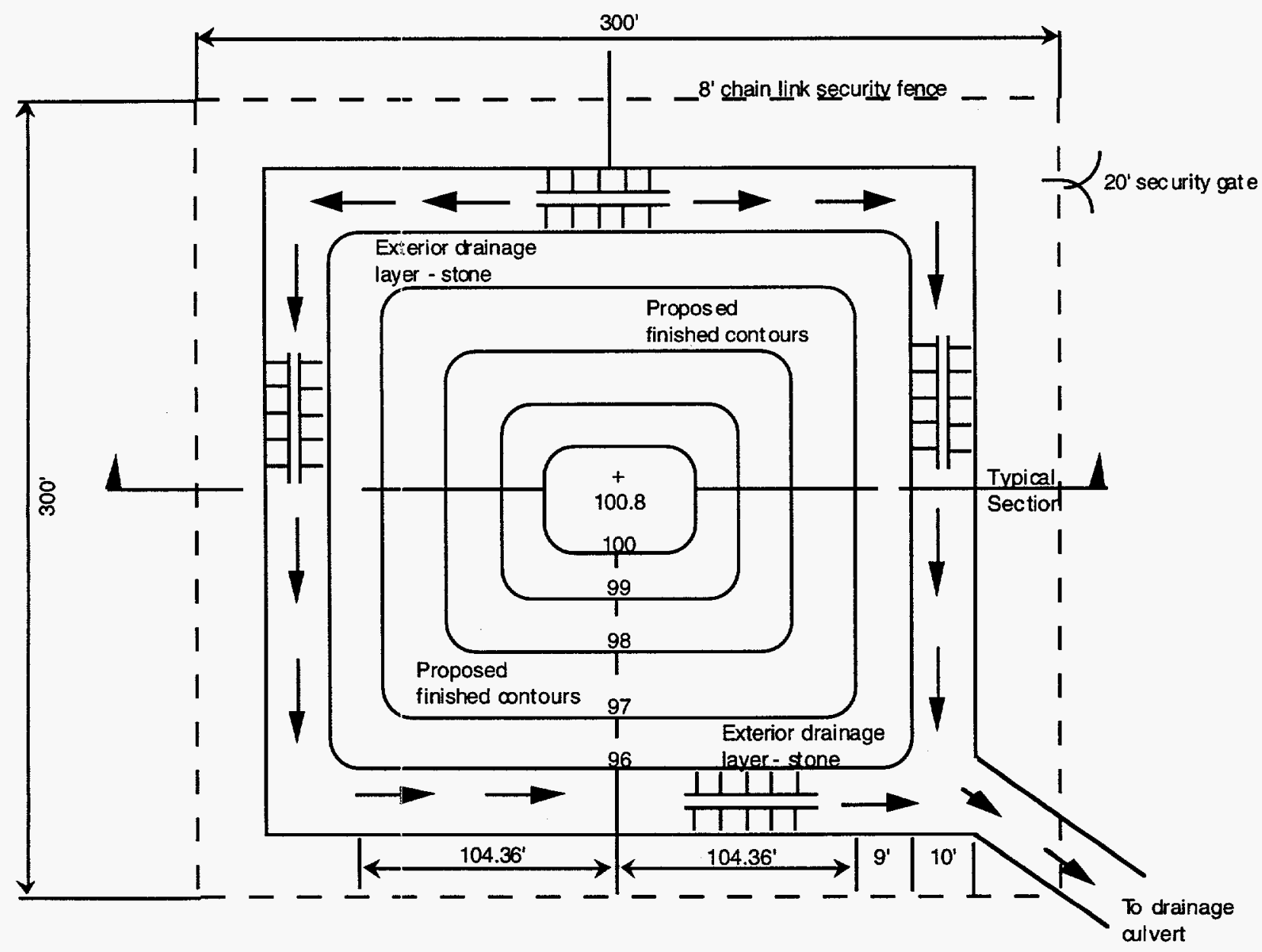

Not to Scale

Figure A-1. Plan for a cover system covering a typical one-acre waste site

\section{A.1.1.5 Establishment of Support Facilities}

Support facilities for construction would include offices, repair shops, decontamination facilities. toilets, water supply, telephone, etc.

\section{A.1.1.6 Establishment of Internal Access Roads and Soil Stockpiles}

Internal access roads will be required for the transportation and placement of the cover materials to the site and for access to construction material stockpiles.

\section{A.1.1.7 Proper Placement of Construction Warning Signs}

This includes erecting the warning signs and other barriers for safeguarding the construction workers and construction site visitors. 


\section{A.1.2 Cover System Construction}

Activities for the construction of the cover system could include the following:

- waste site stabilization (assuming dirty closure)

- placement of foundation material

- placement of barrier cover material

- placement of flexible membrane liner (FML) if required

- placement of drainage layer

- placement of geotextile filter

- placement of vegetative layer

- placement of other miscellaneous materials and monitoring equipment

- removal of temporary site facilities and final site clearance

- erection of security fence and gates

- removal of silt fence/dikes or filling in the sedimentation basins

\section{A.1.2.1 Waste Stabilization}

This involves addition of lime in sufficient quantities to maintain a high $\mathrm{pH}$ between 11.0 and 11.5 to stabilize the waste materials and destroy pathogens or some other in situ treatment method(s), depending on the characteristics of the hazardous waste materials.

\section{A.1.2.2 Placement of Foundation Materials}

This will require hauling the foundation material from an onsite stockpile of suitable soil and placing it in 8-inch lifts. The soil will have to be compacted to at least $95 \%$ standard proctor in order to minimize settlement. To ensure proper compaction of the foundation material, inplace-soil testing for proper compaction densities will be required. The compacted foundation layer must be graded to a 3-5\% slope or other slopes as specified by the design agency.

\section{A.1.2.3 Placement of Barrier Cover Material and FML}

This will involve the placement of the barrier material, for example a geotextile bentonite clay mat. Bentonite mats are placed by unrolling and providing the necessary side and end laps. They are usually held in place by soil pins or staples. Anchor trenches are utilized on slopes to provide slope stability.

Placement of FML will require placing the mainframe (predetermined roll or panel layout supplied by the manufacturer) and forming the side and end seams. These seams must be inspected for water tightness. The membrane must be anchored in an anchor trench for slope stability.

\section{A.1.2.4 Placement of the 12-inch Drainage Layer}

This will require the placement of a properly graded drainage layer and toe drains or exit drains that consist of PVC piping encased in the drainage layer material. A geosynthetic filter is normally placed on top of the drainage layer to prevent fines from filtering down from the vegetative layer above and clogging the drainage layer. 


\section{A.1.2.5; Placement of the 24-inch Vegetative Layer}

This will involve the placement of topsoil by spreading and compacting, native soil for slope as well as fill. It also involves fine grading and seeding, including fertilizer and seed.

\section{A.1.2.6 Placement of Miscellaneous Materials and Monitoring Equipment}

This would include:

- drilling and installation of monitoring wells

- erecting security fence

- erecling site entrance gates

- erecling warning signs

- constructing subsidence monitoring monuments

\section{A.1.2.7 Removal of Temporary Site Facilities and Final Site Clearance}

This would involve removal of temporary barriers, facilities, sedimentation basins, and decontamination and demobilization activities; a survey of the final cover; and the preparation of closure certification documents, etc.

\section{A.1.3 Postclosure Maintenance}

Postclosure activities are primarily operation and maintenance activities, which may occur monthly, quarterly, and annually. Quarterly activities may include groundwater monitoring, sampling, testing, and analysis; air monitoring, sampling, testing, and analysis; leachate removal; and inspection of the cover system. Annual activities may include routine maintenance of wells, pumps, and other equipment, as well as repairs of facilities, cover systems, roads, and fencing.

\section{A.1.3.1 Groundwater Monitoring}

Activities included for groundwater monitoring are quarterly water sampling, lab testing, and analyzing of the groundwater, and report writing. This activity occurs throughout the 30 -year postclosure period.

\section{A.1.3.2. Air Monitoring}

This activity, like groundwater monitoring, will occur throughout the postclosure phase and includes quarterly sampling, laboratory analysis, and report writing.

\section{A.1.3.3 Inspection Activities}

The activities may also occur monthly, quarterly, and annually throughout the postclosure phase.

\section{A.1.3.4 Leachate Removal}

Removal of leachate from the site may also be required on a quarterly basis, but has not been considered in this study. Leachate is water that percolates through the waste material, solubilizing various components of the waste and becoming polluted. Removal of the leachate will occur throughout the postclosure phase. Activities include sampling and analyzing of the leachate, leachate removal, and transport to offsite disposal. 


\section{A.1.3.5 Subsidence Monitoring}

Subsidence occurring because of biodegradation of waste materials or settlement of soil will be monitored annually or more frequently, if necessary, using conventional surveying methods. If depressions occur because of subsidence within the cover system, they need to be remediated to alleviate long-term subsidence resulting from ponding of water in the depressed cover area.

\section{A.1.3.6 Surface Erosion}

All vegetative cover systems are subject to erosion and, therefore, require periodic maintenance. It has been estimated that cover systems with moderate slopes and an agricultural cover will typically require annual maintenance of 0.5 percent of their surface area; this percentage increases with slope. Thus, all covers require an annual inspection and repair program. Such repair may include clearing out surface water swales, replacing cover soil, reestablishing vegetation, and crack repair for hard surface covers. Areas of the vegetative cover requiring repeated repair may benefit from using geosynthetic erosion control blankets.

\section{A.1.3.7 Mulching and Mowing}

The vegetative cover will need periodic mowing to prevent the growth of deep-rooted vegetation. Reseeding, fertilizing, and mulching may also be required to enhance the growth and maintain the integrity of the vegetative cover.

\section{A.1.3.8 Security Fence and Signs}

Security fence, gates, and signs will also require annual inspection and maintenance. 


\section{Appendix A-2}

Major Activities Involved in the Construction of a Cover System Utilizing Claymax/Bentomat/Gundseal 


\section{A.2 Major Construction Activities for a Cover System Utilizing

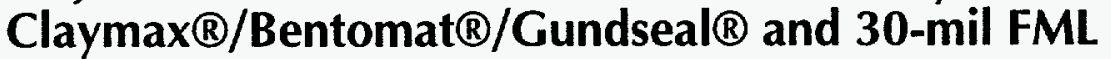

\section{A.2.1 Cover System Utilizing Claymax® and 30-mil FML}

The major construction activities involved in constructing a cover system utilizing Claymax ${ }^{\circledR}$ and a 30-mil FML as a hydraulic barrier will be the same as described in Appendix A-1. The construction activities will follow three phases:

- site preparation

- cover system construction

- postclosure maintenance

\section{A.2.1.1 Site Preparation}

Activities for site preparation will be the same as discussed in Appendix A-1.

\section{A.2.1.2 Cover System Construction}

The major sequential construction activities for a cover system utilizing Claymax ${ }^{\circledR}$ and a 30mil FML, as shown in Figure A-2, will be the following:

- $\quad$ stabilizing waste with limestone (assumed for this study)

- placing and compacting foundation soil material in 8-inch lifts to $95 \%$ standard proctor density

- grading the top of the foundation layer to final grades (as determined by Design Agency) and removal of all sharp objects

- rolling of the surface grade with light smooth roller and removal of all sharp objects

- placing the Claymax $\otimes$ sheets

- placing a 30-mil flexible membrane liner

- placing a 12-inch-thick drainage layer and necessary toe drains to convey percolating water from the vegetative layer to the drainage ditch

- placing a geosynthetic filter on top of the drainage layer as shown in Figure A-2

- placing the 24 -inch vegetative layer with a 3-5\% slope

- seeding, liming, fertilizing, and mulching the vegetative surface area

For more details regarding these construction activities, refer to Appendix A-1.

\section{A.2.1.3 Postclosure Maintenance}

Postclosure maintenance activities will be similar to those discussed in Appendix A-1.

\section{A.2.2 Cover System Utilizing Bentomat ${ }^{\circledR}$ and 30-mil FML}

Construction activities for a cover system utilizing Bentomat 8 and a 30-mil FML will be same the as discussed in Appendixes A-1 and A-2 and include:

- site preparation

- cover system construction

- postclosure maintenance 


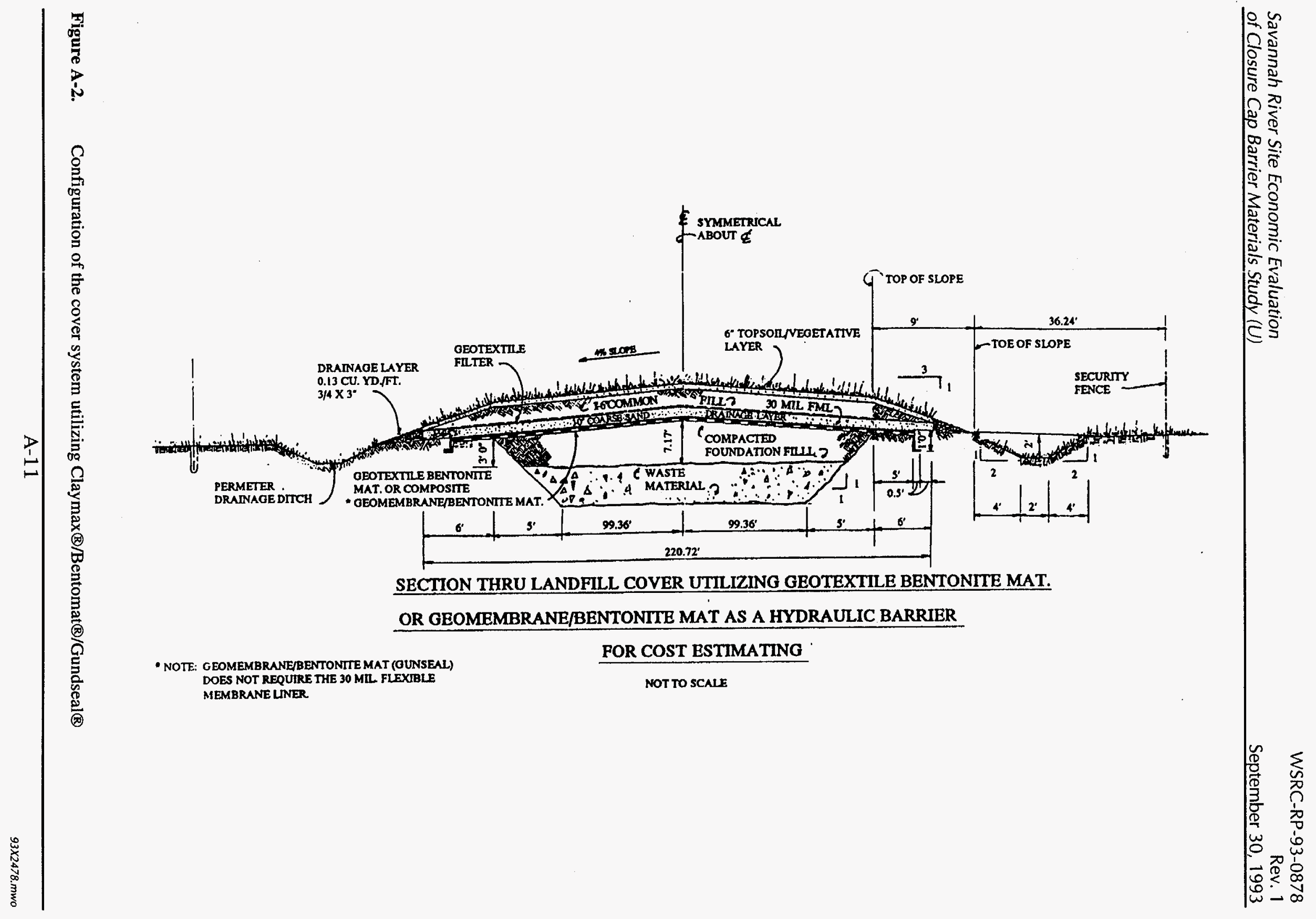




\section{A.2.2.1 Site Preparation}

Site preparation includes the same activities as discussed in Section A.1.1 (Appendix A-1).

\section{A.2.2.2 Cover Systems Construction}

The major sequential construction activities (as shown in Figure A-2) will be the following:

- $\quad$ stabilizing the waste with limestone (assumed for this study)

- placing and compacting the foundation soil material in 8-inch lifts to $95 \%$ standard proctor density

- grading of the top of the foundation layer to final grades (as determined by the design agency)

- rolling of the surface grade with light smooth roller and removal of all sharp objects

- placing the Bentomat ${ }^{\circledR}$ sheets

- placing a 30-mil flexible membrane liner

- placing a 12-inch-thick drainage layer and necessary toe drains to convey percolating water to the exterior drainage ditch

- placing a geosynthetic filter on top of the drainage layer as shown in Figure A-2

- placing the 24 -inch vegetative layer with a 3-5\% slope

- seeding, liming, fertilizing, and mulching the vegetative surface area

For more detailed discussion refer to Appendix A-1.

\section{A.2.2.3 Postclosure Maintenance}

Postclosure maintenance activities will be the same as described in Section A.1.3 (Appendix A-1).

\section{A.2.3 Cover System Utilizing Gundseal ${ }^{\circledR}$}

Like the cover system utilizing Bentomat ${ }^{\circledR}$, this cover system would involve three phases:

- site preparation

- cover system construction

- postclosure maintenance

\section{A.2.3.1 Site Preparation}

Activities included in site preparation are the same as discussed in Section A.1.1 (Appendix A-1).

\section{A.2.3.2 Cover System Construction}

The major sequential construction activities involved in placing the cover system utilizing Gundseal@, as shown in Figure A-2, are the following:

- $\quad$ stabilizing the waste materials with limestone (assumed for this study)

- placing and compacting the foundation soil material in 8-inch lifts to $95 \%$ standard proctor density

- grading the top of the foundation layer to final grades (as determined by the design agency) and removal of all sharp objects

- rolling of the surface grade with light smooth roller and removal of all sharp objects

- placing the Gundseal $\circledast$ sheets (geomembrane side facing up)

- placing a 30-mil flexible membrane liner 
- placing a 12-inch-thick drainage layer and necessary toe drains to convey percolating water to the exterior drainage ditch

- placing a geosynthetic filter on top of the drainage layer as shown in Figure A-2

- placing a 24 -inch vegetative layer with 3-5\% slope

- seeding, liming, fertilizing, and mulching the vegetative surface area

For more details, refer to Appendix A-1.

\section{A.2.3.3 Postclosure Maintenance}

Postclosure maintenance activities will be the same as discussed in Section A.1.3 (Appendix A-1). 


\section{Appendix A-3}

Major Activities Involved in the Construction of a Cover System Utilizing 120-mil Flexible Membrane Liner/1/4-inch Thick Hot Sprayed Asphalt Barrier/1/4-inch Thick Hot Sprayed Asphalt Barrier Reinforced With One Geotextile Layer 


\section{A.3 Major Construction Activities for a Cover System Utilizing 120-mil Flexible Membrane Liner/1/4-Inch Thick Hot-Sprayed Asphalt Barrier/1/4-Inch Thick Reinforced Hot-Sprayed Asphalt Barrier}

\section{A.3.1 Cover System Utilizing 120-mil Flexible Membrane Liner}

The cover system utilizing 120-mil FML (refer to Figure A-3) would involve three phases:

- site preparation

- cover system construction

- postclosure maintenance

\section{A.3.1.1 Site Preparation}

Activities included in this phase will be the same as discussed in Section A.1.1 (Appendix A1).

\section{A.3.1.2 Cover System Construction}

The major construction activities, in sequential order, will be the following (refer to Figure A3):

- $\quad$ stabilizing the waste materials with limestone

- placing and compacting the foundation soil material in 8-inch lifts to $95 \%$ standard proctor density

- grading the top of the foundation layer to final grades as determined by the design agency and removal of all sharp objects

- rolling the surface grade with light smooth roller

- placing a 120-mil flexible membrane liner

- placing a 12 -inch-thick drainage layer and necessary toe drains to convey percolating water to the exterior drainage ditch

- placing a geosynthetic filter on top of the drainage layer as shown in Figure A-3

- placing the 24 -inch vegetative layer involving placement of common fill and topsoil by spreading and compaction

- finishing vegetative surface area to a 3-5\% slope

- seeding, liming, fertilizing and mulching the vegetative surface area

For more details, refer to Appendix A-1.

\section{A.3.1.3 Postclosure Maintenance}

Postclosure activities will be same as discussed in Section A.1.3 (Appendix A-1). 


\section{A.3.2 Cover System Utilizing Hot-Sprayed Asphalt}

The cover system utilizing hot-sprayed asphalt would involve the following three phases (refer to Figure A-3):

- site preparation

- cover system construction

- postclosure maintenance

\section{A.3.2.1 Site Preparation}

Activities included in this phase will be the same as discussed in Section A.1.1 (Appendix A1).

\section{A.3.2.2 Cover System Construction}

The major construction activities involved in the construction of a cover system utilizing hot sprayed asphalt will be the following (refer to Figure A-3):

- stabilizing the waste materials with limestone

- placing and compacting the foundation soil material in 8-inch lifts to $95 \%$ standard proctor density

- grading top of the foundation layer to final grades as determined by the design agency and removal of all sharp objects

- $\quad$ rolling the surface grade with light smooth roller

- sprinkling of water over the subgrade prior to spraying asphalt

- application of hot asphalt membrane 1/4-inch thick spraying under pressure by using spray bars (asphalt applied at $1.5 \mathrm{gal} / \mathrm{yd}^{2}$, three passes each at about $0.5 \mathrm{gal} / \mathrm{yd}^{2} \mathrm{yields}$ a desirable "ply" affect).

- placing a 3-inch sand layer for cushion affect

- placing a 30-mil FML

- placing a 12-inch-thick drainage layer and necessary toe drains to convey percolating water through the vegetative layer to the exterior drainage ditch

- placing a geosynthetic filter on top of the drainage layer

- placing a the 24-inch vegetative layer involving placement of common fill and topsoil by spreading and compaction

- grading finished vegetative surface area to 3-5\% slope

- seeding, liming, fertilizing, and mulching the vegetative surface area

Fore more details, refer to Appendix A-1.

\section{A.3.2.3 Postclosure Maintenance}

Postclosure activities will be the same as discussed in Section A.1.3 (Appendix A-1).

\section{A.3.3 Cover System Utilizing Reinforced Sprayed Asphalt}

Following major activities are involved in the construction of a cover system utilizing reinforced sprayed asphalt (refer to Figure A-3):

- site preparation

- cover system construction

- postclosure maintenance 


\section{A.3.3.1 Site Preparation}

Activities included in site preparation will be same as discussed in Section A.1.1 (Appendix A-1).

\section{A.3.3.2 Cover System Construction}

The major construction activities involved in sequential order will be the following (refer to Figure A-3):

- $\quad$ stabilizing the waste materials with limestone (assumed for this study)

- placing and compacting the foundation soil material in 8-inch lifts to $95 \%$ standard proctor density

- grading top of the foundation layer to final grades as determined by the design agency and removal of all sharp objects

- rolling the surface grade with light smooth roller

- placing a geosynthetic material for asphalt reinforcement as shown in Figure A-9

- application of hot asphalt membrane $1 / 4$-inch thick sprayed under pressure by using spray bars (asphalt applied at $1.5 \mathrm{gal} / \mathrm{yd}^{2}$, three (3) passes each pass at about $0.5 \mathrm{gal} / \mathrm{yd}^{2}$ yields a desirable "ply" affect).

- placing a 3-inch sand layer for cushion affect

- placing a 30-mil FML

- placing a 12-inch-thick drainage layer and necessary toe drains to convey percolating water through the vegetative layer to the exterior drainage ditch

- placing a geosynthetic filter on top of the drainage layer

- placing the 24-inch vegetative layer involving placement of common fill and topsoil by spreading and compaction

- finishing the grade of vegetative surface are to a 3-5\% slope

- seeding, liming, fertilizing, and mulching the vegetative surface area

Fore more details, refer to Appendix A-1.

\section{A.3.3.3 Postclosure Maintenance}

Postclosure activities will be the same as discussed in Section A.1.3 (Appendix A-1). 


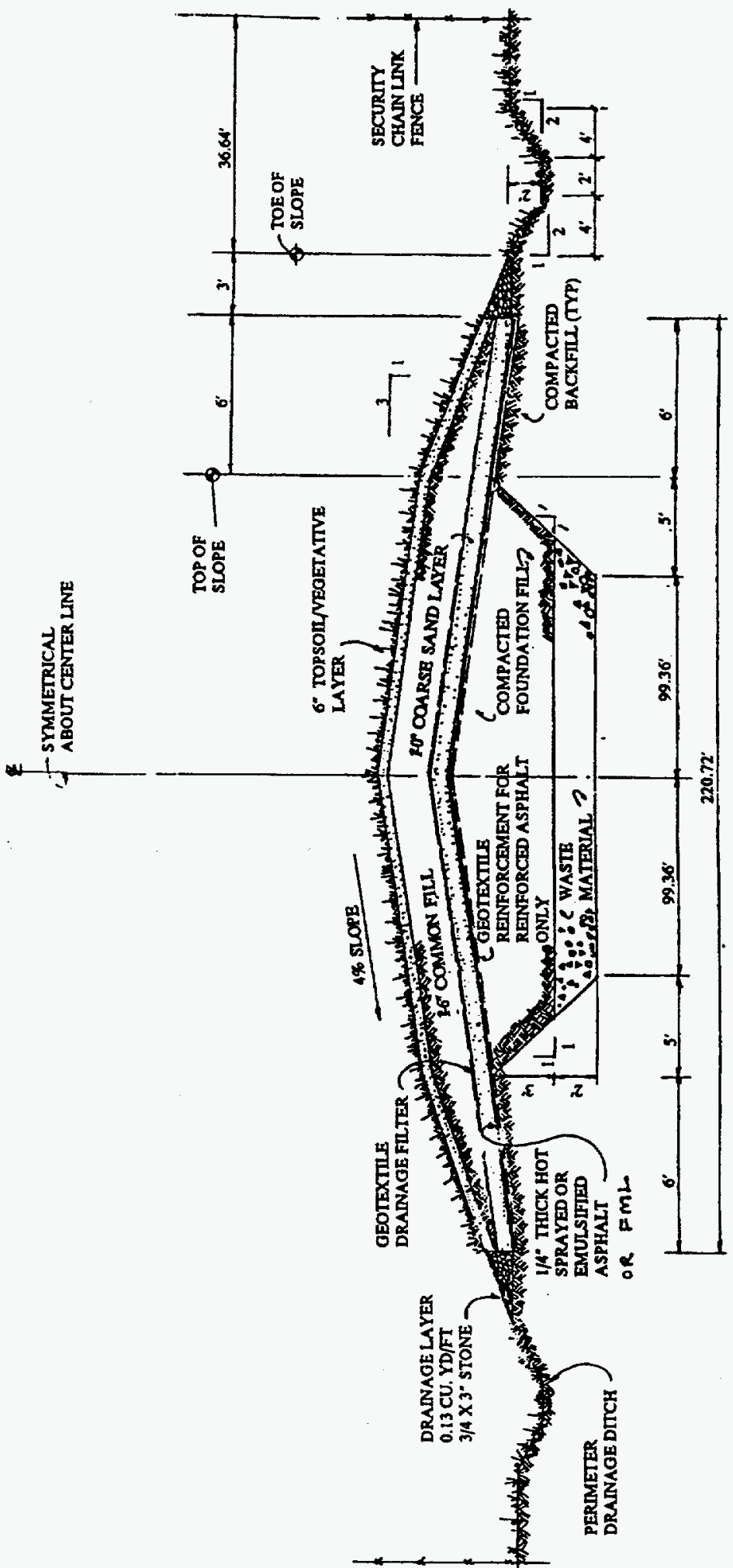

Figure A-3. Configuration of the cover system utilizing 120-mil flexible membrane liner/1/4-inch thick hot sprayed asphalt/1/4-inch thick reinforced sprayed asphalt 
Appendix A-4

Major Activities Involved in the Construction of a Cover System Utilizing Compacted Kaolin Clay/On-Site or Off-Site Clay 


\section{A.4 Major Construction Activities for a Cover System Utilizing Compacted Kaolin Clay/Onsite or Offsite Clay}

\section{A.4.1 Cover System Utilizing Kaolin Clay}

Three phases involved in the closure of a site utilizing compacted kaolin clay will be the following:

- site preparation

- cover system construction

- postclosure maintenance

\section{A.4.1.1 Site Preparation}

Activities included in site preparation are the same as discussed in Section A.1.1 (Appendix A-1).

\section{A.4.1.2 Cover System Construction}

The major construction activities in the placement of cover system utilizing compacted kaolin clay will be the following (refer to Figure A-4):

- stabilizing the waste materials with limestone (assumed for this study)

- placing and compacting the foundation soil material in 8-inch lifts to $95 \%$ standard proctor density

- grading of the top of the foundation layer to final grades as specified by the design agency and removal of all sharp objects

- placement and compaction of the clay cover to achieve a permeability of $1 \times 10^{-7} \mathrm{~cm} / \mathrm{s}$.

- grading the top surface of the clay cover to 3-5\% slope

- placing a 30-mil flexible membrane liner

- placing a 12-inch-thick drainage layer and necessary toe drains to convey percolating water to the exterior drainage ditch

- placing the geosynthetic filter on top of the drainage layer

- placing the 24-inch vegetative layer involving placement of common fill and topsoil by spreading and compaction.

- finishing the vegetative layer top surface to $3-5 \%$ slope

- seeding, liming, fertilizing, and mulching the vegetative surface area

For more details, refer to Appendix A-1.

\section{A.4.1.3 Postclosure Maintenance}

Post closure activities will be the same as discussed in Section A.1.3 (Appendix A-1). 


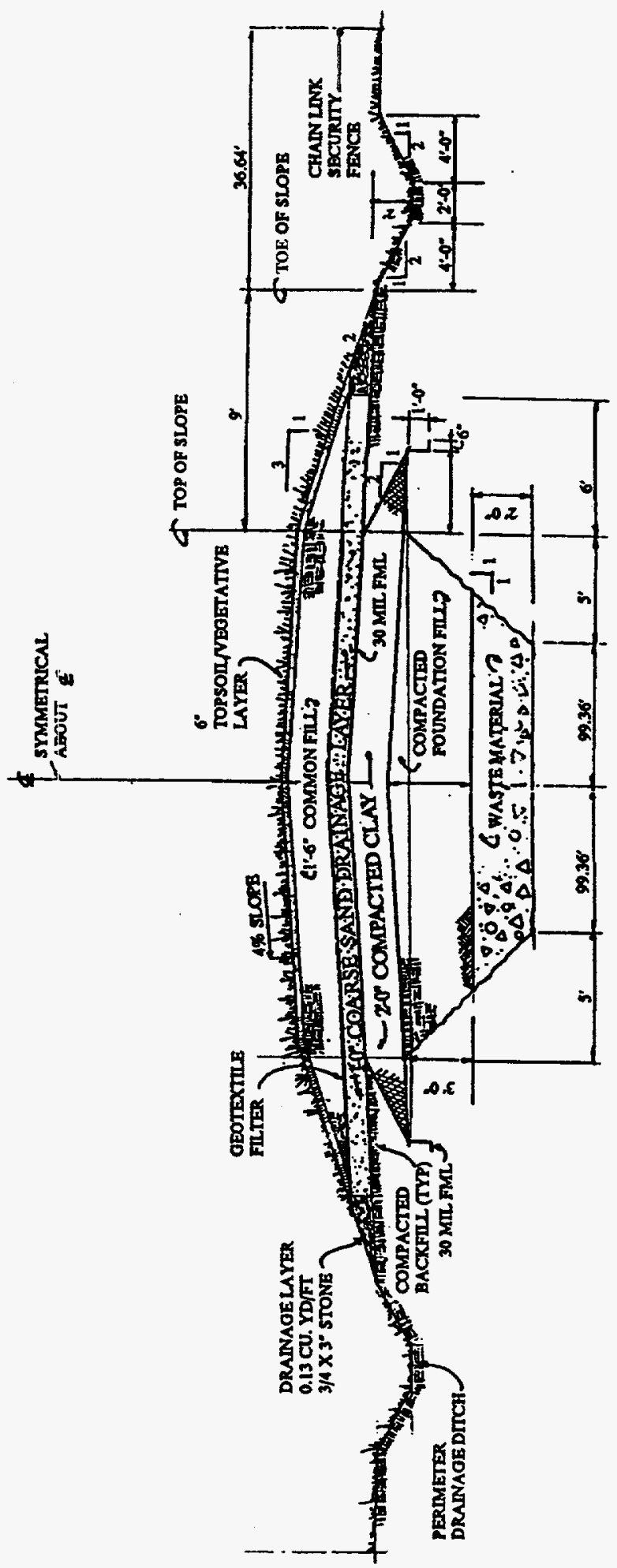

Figure A-4. Configuration of the cover system utilizing compacted kaolin clay/onsite or offsite clay and 30-mil FML 


\section{Appendix A-5}

Major Activities Involved in the Construction of a Cover System Utilizing Soil Cement/Bentonite Soil Additive 


\section{A.5 Major Construction Activities for a Cover System Utilizing Soil Cement/Bentonite Soil Additive}

\section{A.5.1 Cover System Utilizing Soil Cement}

Three phases for the construction of a cover system utilizing soil cement will be the following:

- site preparation

- cover system construction

- postclosure maintenance

\section{A.5.1.1 Site Preparation}

Activities included in site preparation are the same as discussed in Section A.1.1 (Appendix A-1).

\section{A.5.1.2 Cover System Construction}

The major sequential construction activities will be the following (refer to Figure A-5):

- stabilizing the waste materials with limestone (assumed for this study)

- placing and compacting the foundation soil material in 8-inch lifts to $95 \%$ standard proctor density

- grading of the top of the foundation layer to final grades as specified by the design agency

- moistening the finished surface to receive the soil-cement mixture

- placing the soil-cement mixture in 6-8 inches lifts by spreaders transported from the central mixing plant and placed by end-dump trucks

- compacting the soil-cement mixture uniformly to a minimum of $95 \%$ and an average of 98\% maximum density

- curing the soil-cement slab by keeping moist for seven days or by other suitable curing materials

- placing a 30-mil flexible membrane liner

- placing a 12-inch-thick drainage layer and necessary toe drains to convey percolating water to the exterior drainage ditch

- placing a geosynthetic filter on top of the drainage layer

- placing the 24-inch vegetative layer involving placement of common fill and topsoil by spreading and compaction

- grading the finished vegetative surface to 3-5\% slope

- seeding, liming, fertilizing, and mulching the vegetative surface area

For more details, refer to Appendix A-1.

\section{A.5.1.3 Postclosure Maintenance}

Postclosure activities will be the same as discussed in Section A.1.3 (Appendix A-1). 


\section{A.5.2 Cover System Utilizing Bentonite Soil Additive}

The three phases for the construction activities will be the same as discussed in A.5.1.

\section{A.5.2.1 Site Preparation}

Activities will be the same as for cover system utilizing soil cement.

\section{A.5.2.2 Cover System Construction}

The major sequential activities will be the following (Refer to Figure A-5):

- stabilizing the waste materials with limestone (assumed for this study)

- placing and compaction of the foundation soil material in 8-inch lifts to $95 \%$ standard proctor density

- placing a soil and bentonite soil additive mixture in 6-inch lifts to the soil at a rate specified by the design agency. (compact the lift to at least $95 \%$ standard proctor density and shape the top surface to a minimum grade of $3 \%$ and a maximum of $5 \%$ ).

- placing a 30-mil flexible membrane liner

- placing a 12-inch-thick drainage layer and necessary toe drains to convey percolating water to the exterior drainage ditch

- placing a geosynthetic filter on top of the drainage layer

- placing the 24-inch vegetative layer involving placement of common fill and topsoil by spreading and compaction

- grading the finished vegetative surface to a $3-5 \%$ slope

- seeding, liming, fertilizing, and mulching the vegetative surface area

For more details, refer to Appendix A-1.

\section{A.5.2.3 Postclosure Maintenance}

Activities for postclosure maintenance of the cover system will be the same as discussed in Section A.1.3 (Appendix A-1). 


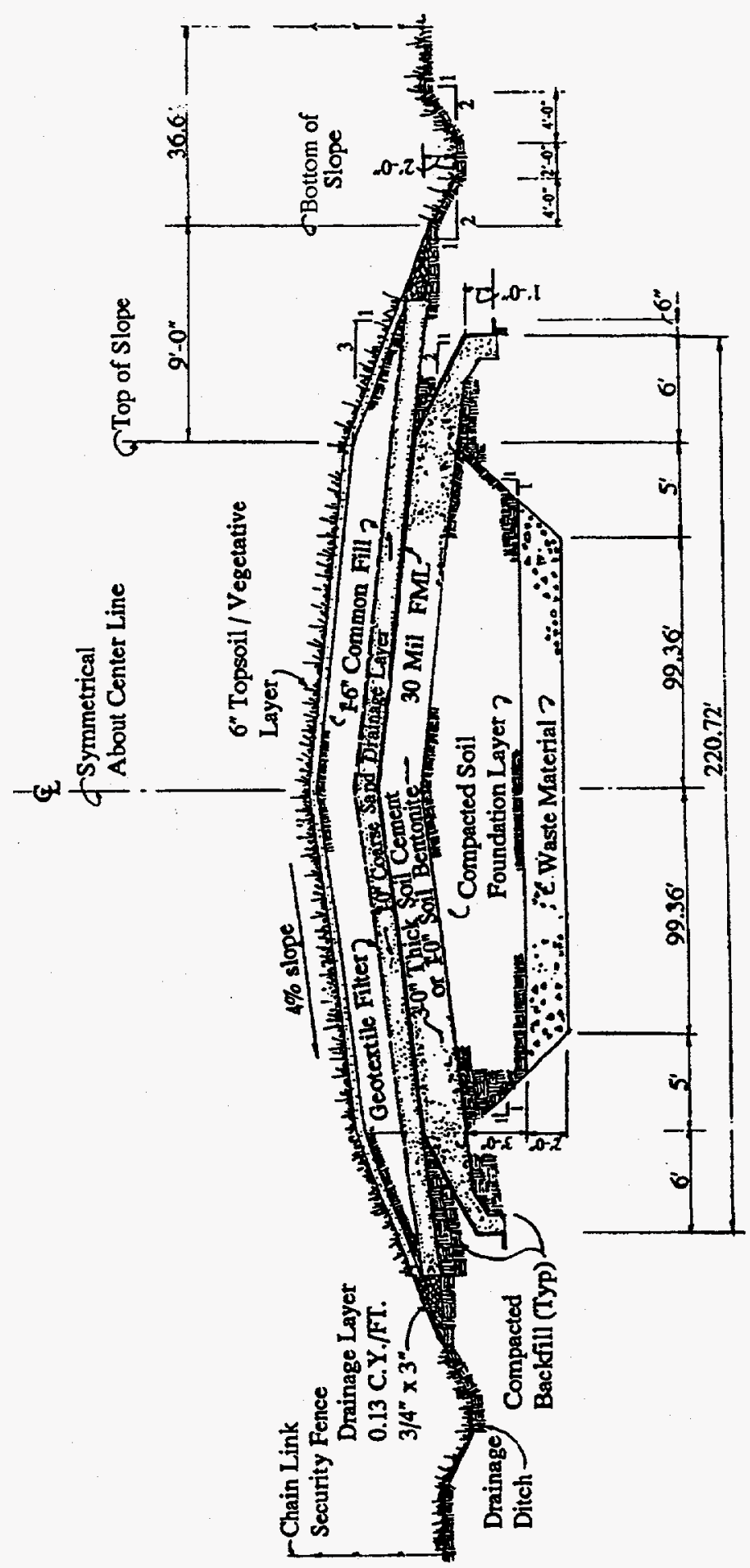

Figure A-5. Configuration of the cover system utilizing soil cement/bentonite soil additive 


\section{Appendix A-6}

Major Activities Involved in the Construction of a Cover System Utilizing Asphalt Concrete 


\section{A.6 Major Construction Activities for a Cover System Utilizing Asphalt Concrete}

Following will be the three phases involved in the construction of a cover system utilizing asphalt concrete and a 30-mil FML.

- site preparation

- cover system construction

- postclosure maintenance

\section{A.6.1 Site Preparation}

Activities included will be the same as discussed in Section A.1.1 (Appendix A).

\section{A.6.2 Cover System Construction}

The major sequential construction activities will be the following (refer to Figure A-6):

- stabilizing the waste materials with the limestone (assumed for this study)

- placing and compaction of the foundation soil material in 8-inch lifts to $95 \%$ standard proctor density

- grading of the top of the foundation layer to final grades as specified by the design agency and all removal of all sharp objects

- rolling the surface grade with light smooth roller

- placing a 30-mil flexible membrane liner

- placing a 12-inch-thick drainage layer and necessary 2-inch PVC drainage pipe to intercept percolating water through the asphalt surface and convey to exterior ditch

- applying a prime coat to the drainage layer and placement of the 2.5 -inch asphalt concrete binder coarse

- placing, spreading, and compacting the 4-inch hydraulic asphalt concrete surface

- applying a $1 / 8$-inch-thick mastic seal to the asphaltic concrete surface

- applying a sprayed asphalt cement sealant to mastic at $0.25 \mathrm{gal} / \mathrm{yd}^{2}$

- finishing the top of cover system from a minimum of $1 \%$ to a maximum of $4 \%$ slope

For additional detail, refer to Appendix A-1.

\section{A.6.3 Postclosure Maintenance}

Activities for the postclosure maintenance will be the same as discussed in Section A.1.3 (Appendix A-1). 


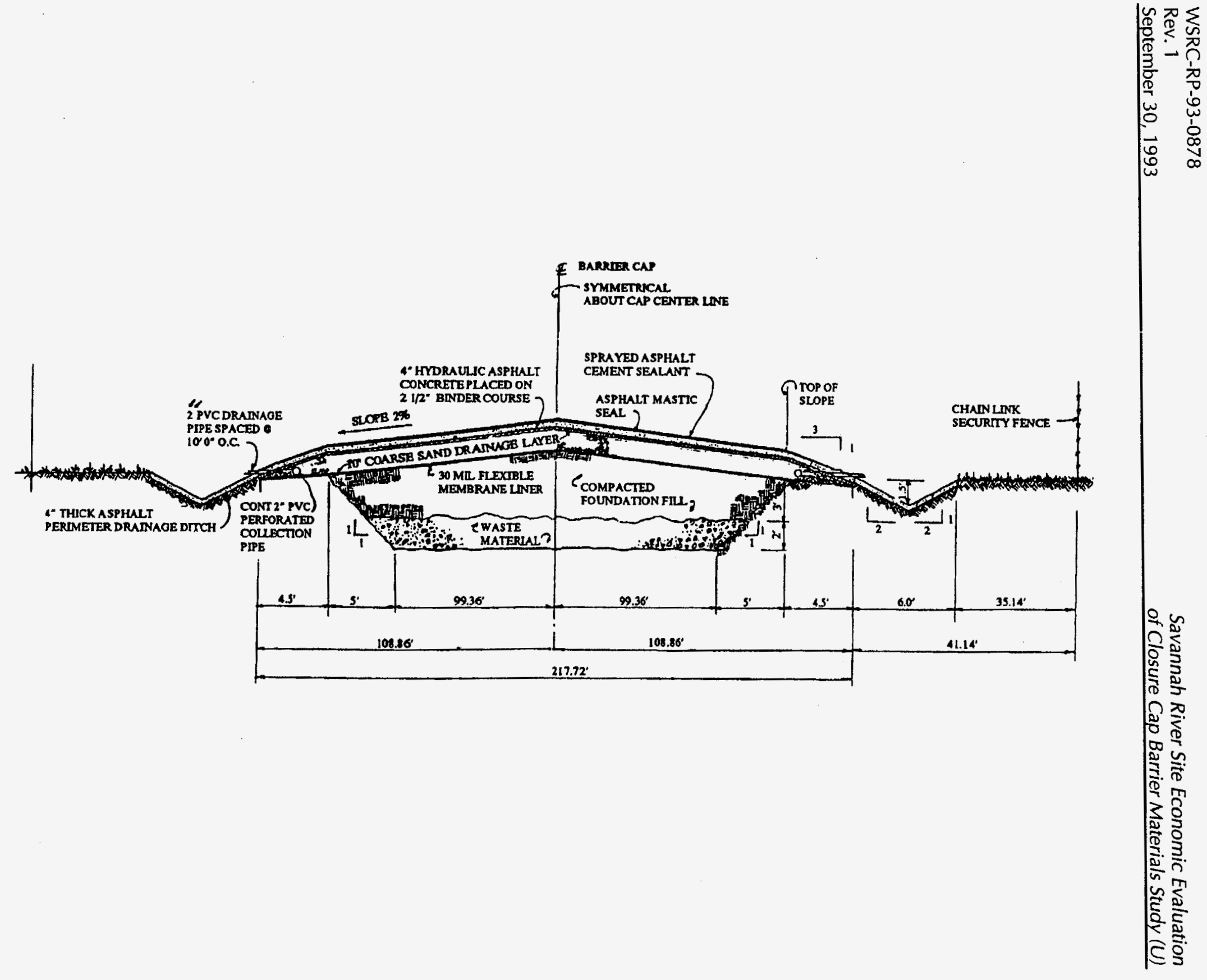




\section{Appendix A-7}

Major Activities Involved in the Construction of a Cover System Utilizing Concrete Slab 


\section{A.7 Major Construction Activities for a Cover System Utilizing Poured-in- Place Concrete Slab}

Three phases involved in the construction of a cover system utilizing poured-in-place concrete slab and a 30-mil FML will be the following:

- site preparation

- cover system construction

- postclosure maintenance

\section{A.7.1 Site Preparation}

Activities included will be the same as discussed in Section A.1.1 (Appendix A).

\section{A.7.2 Cover System Construction}

The major construction activities involved, in sequential order, will be the following (refer to Figure A-7):

- $\quad$ stabilizing the waste materials with limestone (assumed for this study)

- placing and compacting the foundation soil material in 8-inch lifts to $95 \%$ standard proctor density

- grading the top of the foundation layer to final grades as specified by the design agency and removal of all sharp objects

- rolling the surface grade with a light smooth roller

- placing a 30-mil flexible membrane liner

- placing a 12-inch-thick drainage layer and necessary 2-inch PVC drainage pipe to intercept percolating water through the concrete surface and convey to exterior ditch

- placing a 4-inch-thick concrete slab on drainage layer (reinforcement of the slab will be done with one layer of $6 \times 6-$ W2.9 $\times$ W2.9 welded wire fabric and minimum compressive strength of concrete shall be 4,000 psi; all joints will have 6" PVC water stops)

- proper curing of concrete slab with a curing compound

- finishing the top of the cover system from a minimum of $1 \%$ to a maximum of $4 \%$ slope

For additional details, refer to Appendix A-1.

\section{A.7.3 Postclosure Maintenance}

Activities for the postclosure maintenance will be the same as discussed in Section A.1.3 (Appendix A-1). 


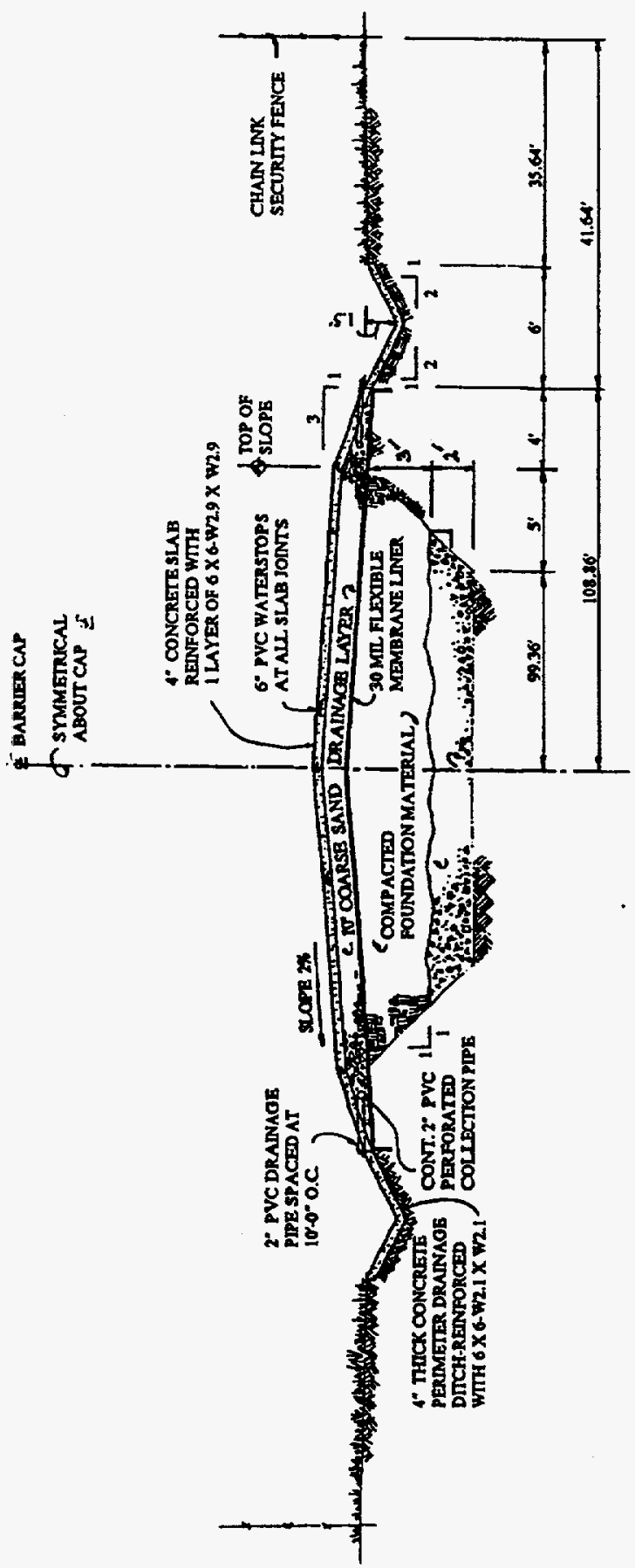

Figure A-17. Configuration of the cover system utilizing concrete slab 
Appendix B

Cost Estimate for a Typical One-Acre Site 
FILE: A.IACRE

DETAILESTIMATE

$1001:$ 7-03

ACTIVITY CODE: ESE260412

PROJ.NAME: ECON. EVALUATION OP CLOSURE CAP BARRIER MATERIAL

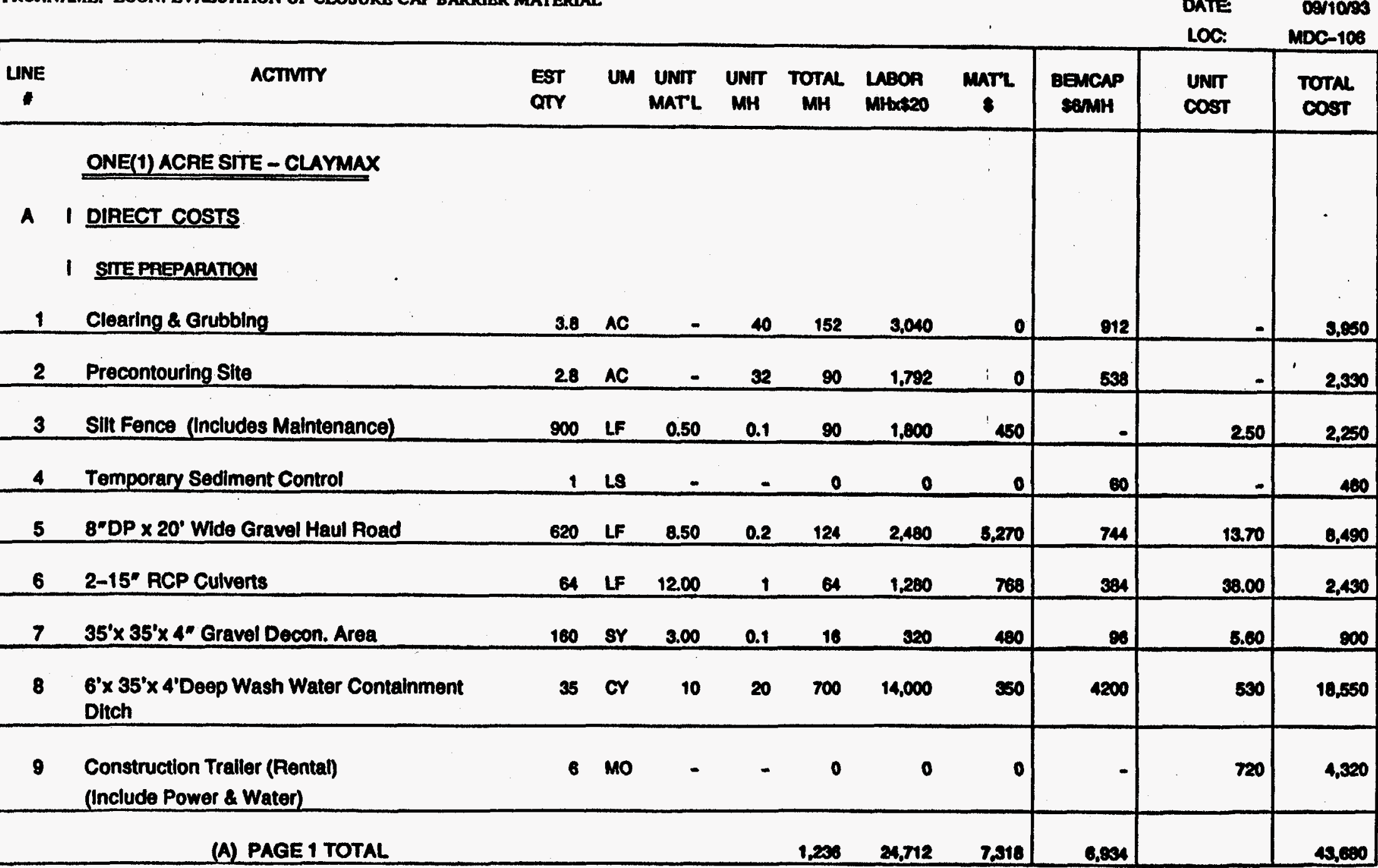




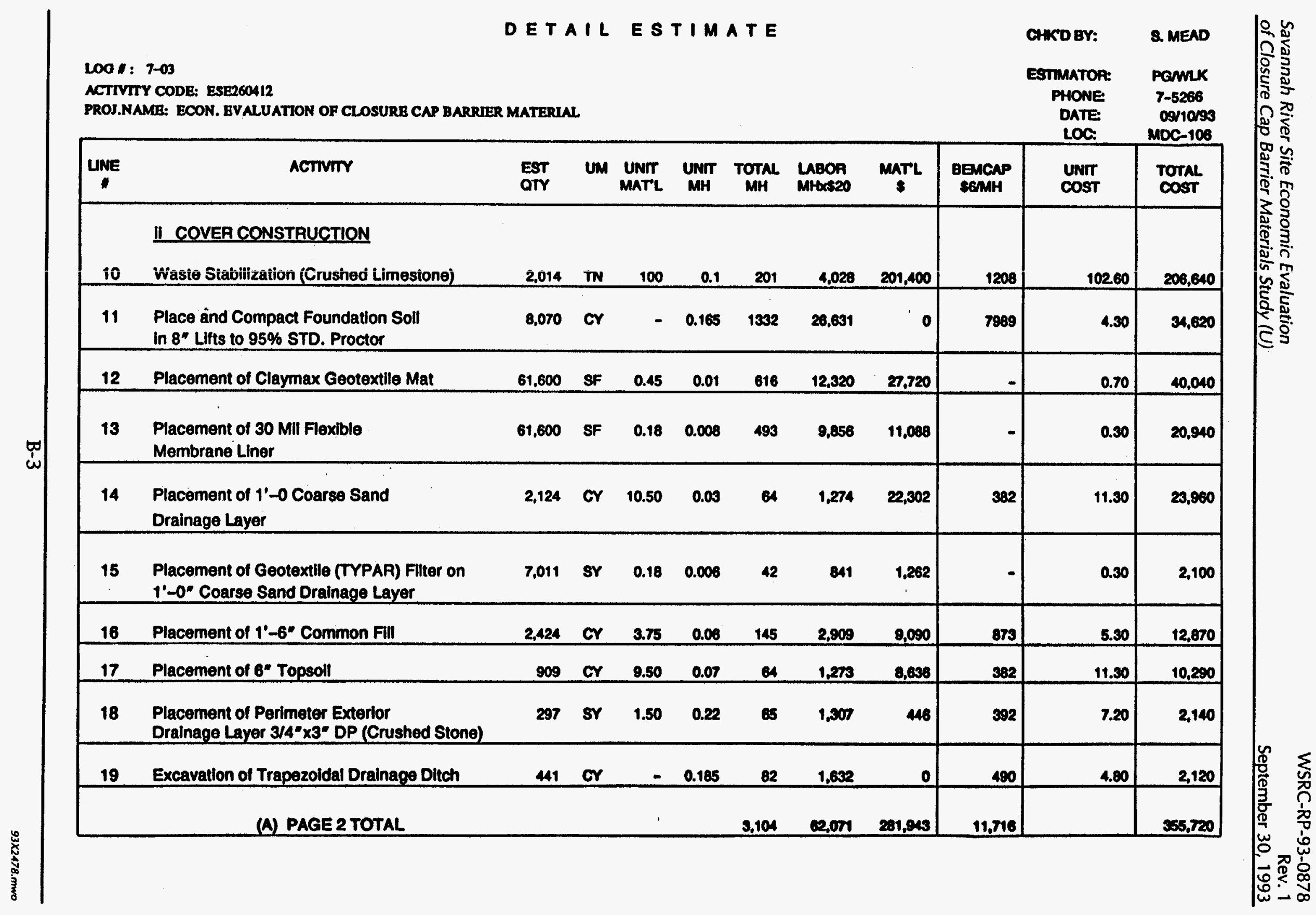


Loo : 7-03

ACTIVITY CODE: ESE260412

PROJ.NAME: ECON. EVALUATION OF CLOSURE CAP BARRIER MATERIAL

CHKD BY: S.MEAD

PHONE

PanvK

DATE:

LOC.

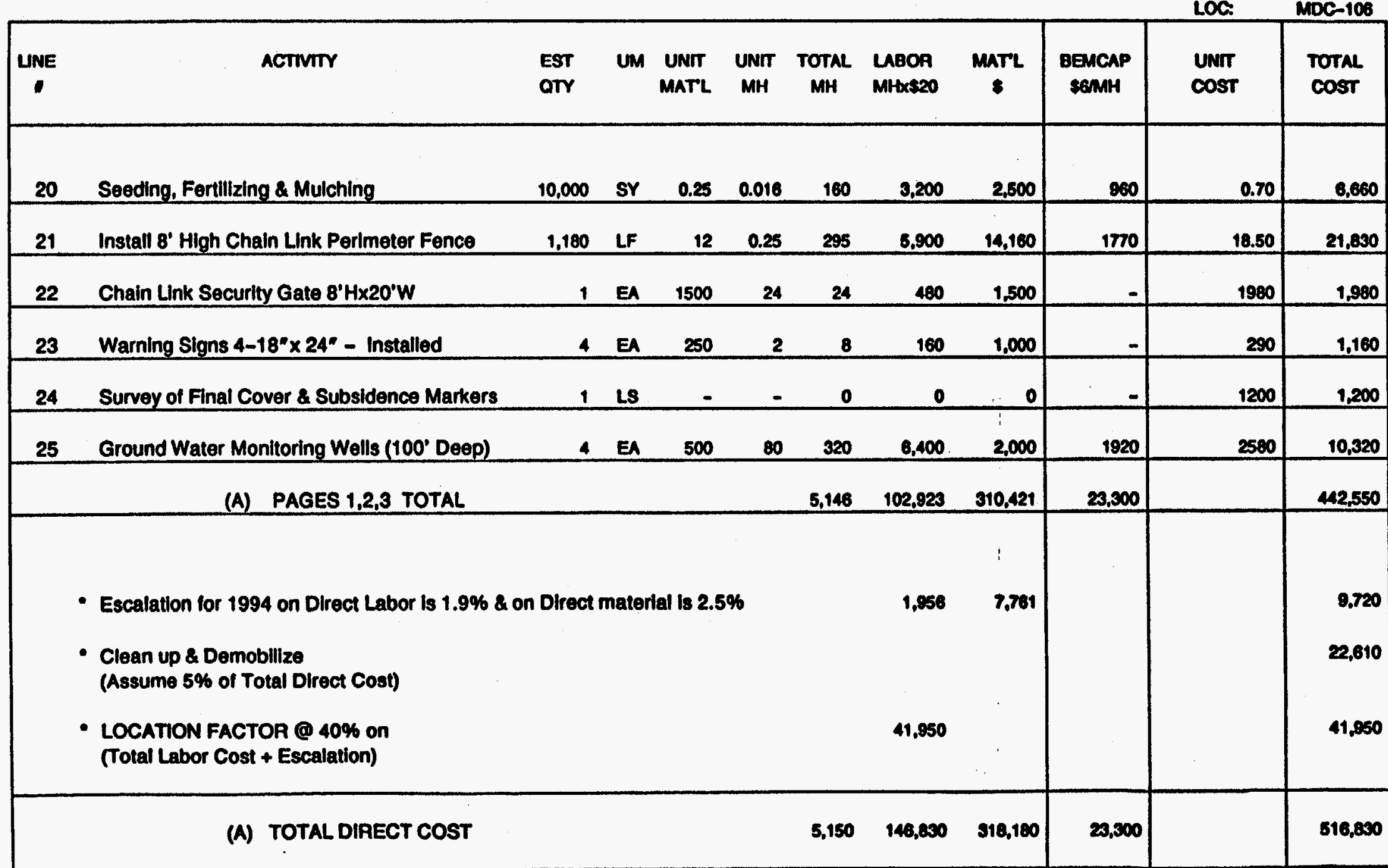




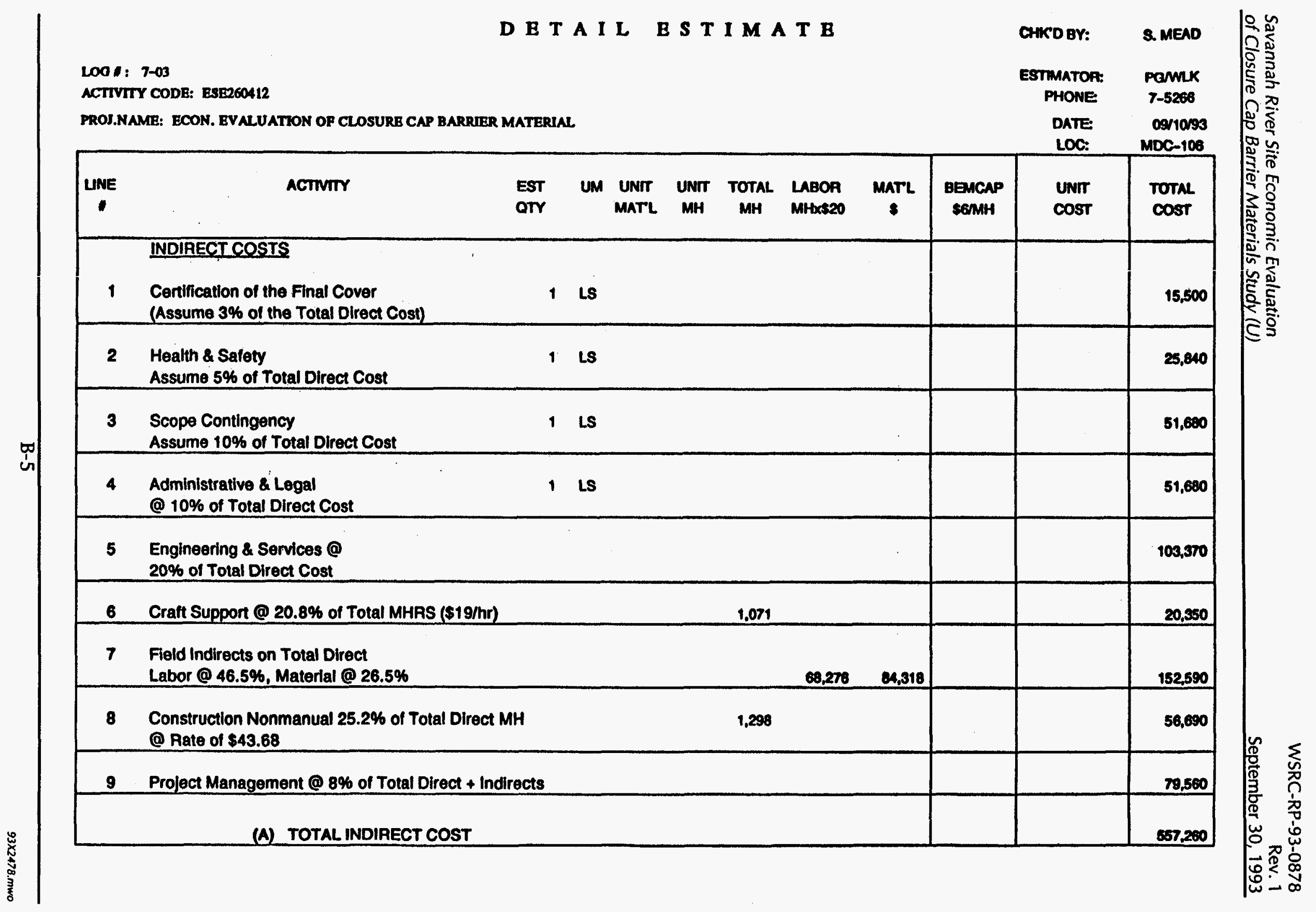


100 : : 7-03

ACTIVITY CODB: ESE260412

PROJ.NAME: ECON. EVALUATION OP CLOSURE CAP BARRIER MATERIAL

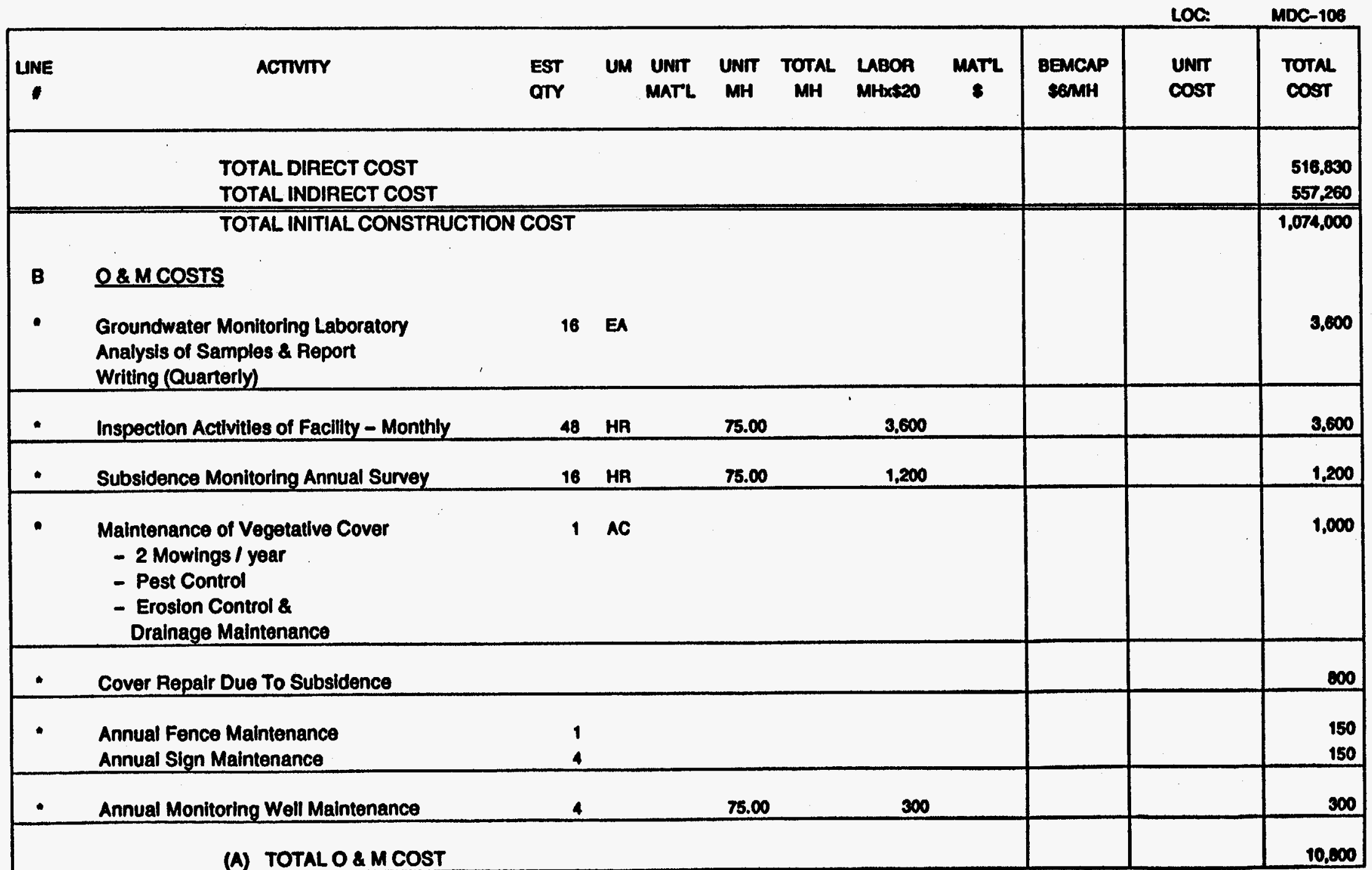


Loof: 7-03

ACTIVITY CODE: ESE260412

ESTMATOR: PannK

PHONE: $\quad 7-5266$

DATE: $\quad$ OSHO93

PROJ.NAME: ECON. EVALUATION OF CLOSURE CAP BARRIER MATERIAL

LOC: MDC-108

\section{SUMMARY}

ONE(1) ACAE SITE - CLAYMAX

C TOTAL COST (Total Present Worth)

(i) Present Worth of $0 \&$ M Cost

( $5 \%$ discount Rate for 30 Years)

(Total O\& M X 15.3725)

(ii) Total Initial Construction Cost 
Appendix C

Data for Calculating Subsidence Failures Repair Costs 
Table C-1. Estimated Sinkhole Repair Costs

\begin{tabular}{llcc} 
Cover Material & $\begin{array}{c}\text { Sinkhole Repair } \\
\text { Cost (1994 } \\
\text { Dollars) }\end{array}$ & Cost Ratio \\
\hline 1. & Gundseal & $\$ 7,500$ & 1.0 \\
2. & 120 Mil FML & $\$ 7,500$ & 1.0 \\
3. & Claymax & $\$ 8,000$ & 1.07 \\
4. & Bentomat & $\$ 8,000$ & 1.07 \\
5. & 1/4" Hot Sprayed Asphalt & $\$ 8,000$ & 1.07 \\
6. & Reinforced Sprayed Asphalt & $\$ 8,000$ & 1.07 \\
7. & Asphaltic Concrete & $\$ 11,500$ & 1.53 \\
8. & Soil Bentonite Add & $\$ 12,000$ & 1.60 \\
9. 2'-0" Offsite Clay & $\$ 18,000$ & 2.40 \\
10. 2'-0" Onsite Clay & $\$ 18,000$ & 2.40 \\
11. Soil Cement & $\$ 18,050$ & 2.47 \\
12. Concrete Slab (22' x 22') & $\$ 21,000$ & 2.80
\end{tabular}

Table C-2. Assumed Frequency of Repair Events for Estimating Cover Repair Costs

\begin{tabular}{|c|c|c|c|c|c|c|c|c|c|c|}
\hline \multirow{2}{*}{$\begin{array}{c}\text { Time } \\
\text { (years) }\end{array}$} & \multicolumn{8}{|c|}{ Number of Repair Events for Cap Size } \\
\cline { 2 - 12 } & $\mathbf{0 . 1}$ & $\mathbf{0 . 2}$ & $\mathbf{0 . 5}$ & $\mathbf{1}$ & $\mathbf{2}$ & $\mathbf{5}$ & $\mathbf{1 0}$ & $\mathbf{2 0}$ & $\mathbf{4 0}$ & $\mathbf{8 0}$ \\
\hline 6 & 0 & 0 & 0 & 0 & 0 & 1 & 2 & 3 & 4 & 5 \\
\hline 12 & 0 & 0 & 0 & 0 & 1 & 2 & 3 & 4 & 6 & 6 \\
\hline 18 & 0 & 1 & 1 & 1 & 2 & 3 & 4 & 6 & 8 & 10 \\
\hline 24 & 1 & 0 & 1 & 2 & 2 & 4 & 6 & 8 & 10 & 12 \\
\hline 30 & 1 & 1 & 1 & 2 & 3 & 6 & 8 & 12 & 15 & 18 \\
\hline Total & 2 & 2 & 3 & 5 & 8 & 16 & 23 & 33 & 43 & 51 \\
\hline
\end{tabular}

